Bulletin of the Natural History Museum, 2018, 11: 101-180.

Received 23 Nov 2018; Accepted 02 Dec 2018.

doi:10.5937/bnhmb1811101N

UDC: 581.9(497.11)

Original scientific paper

\title{
MATERIAL ON THE ANNOTATED CHECKLIST OF VASCULAR FLORA OF SERBIA. NOMENCLATURAL, TAXONOMIC AND FLORISTIC NOTES I
}

\author{
MARJAN NiKETIĆ ${ }^{1 *}$, GORDANA TOMOVIĆ ${ }^{2}$, RANKO PERIĆ ${ }^{3}$, BOJAN \\ ZLATKOVIĆ $^{4}$, GORAN ANAČKOV ${ }^{5}$, VLADAN DJORDJEVIĆ ${ }^{2}$, NEJC JOGAN ${ }^{6}$, \\ BORIS RADAK ${ }^{5}$, ŠEMIJA DURAKI ${ }^{7}$, MIHAJLO STANKOVIĆ ${ }^{8}$, \\ NEVENA KUZMANOVIĆ ${ }^{2}$, DMITAR LAKUŠIĆ ${ }^{2}$, VLADIMIR STEVANOVIĆ 9 \\ ${ }^{1}$ Natural History Museum, 11000 Belgrade, Serbia, e-mail: mniketic@nhmbeo.rs \\ ${ }^{2}$ Institute of Botany and Botanical Garden, Faculty of Biology, University of \\ Belgrade, 11000 Belgrade, Serbia, e-mail: gtomovic@bio.bg.ac.rs, \\ vdjordjevic@bio.bg.ac.rs,nkuzmanovic@bio.bg.ac.rs, dlakusic@bio.bg.ac.rs \\ ${ }^{3}$ Institute for Nature Conservation of Vojvodina province, Radnička 20a, 21101 \\ Novi Sad, Serbia, e-mail: ranko.peric@pzzp.rs \\ ${ }^{4}$ Department of Biology and Ecology, Faculty of Natural Sciences and \\ Mathematics, University of Niš, Serbia, e-mail: bojanzlat@pmf.ni.ac.rs \\ ${ }^{5}$ Department of Biology and Ecology, Faculty of Sciences, University of Novi Sad, \\ Serbia, e-mail: goran.anackov@dbe.uns.ac.rs, boza.pal@dbe.uns.ac.rs, \\ boris.radak@dbe.uns.ac.rs \\ ${ }^{6}$ Department of Biology, University of Ljubljana, Biotechnical faculty, "Večna pot \\ 111, Ljubljana, Slovenia, e-mail: nejc.jogan@bf.uni-lj.si \\ ${ }^{7}$ Eight Belgrade Grammar School, Grčića Milenka 71, 11000 Belgrade, Serbia, e- \\ mail: semijaduraki@gmail.com \\ ${ }^{8}$ Nature Conservation Movement of Sremska Mitrovica, Serbia, e-mail: \\ trogloxen@gmail.com \\ ${ }^{9}$ Serbian Academy of Sciences and Arts, Kneza Mihaila 35, 11000 Belgrade, \\ Serbia, e-mail: vstev@bio.bg.ac.rs
}

The paper presents three new nomenclature combinations related to representatives of the orchid family. In addition, 14 taxa (species, subspecies and hybrids) of vascular flora which are newly registered for Serbia (of which 8 are autochthonous and 6 allochtonous plants) are presented. A confirmation of old or unreliable 
literature records for four autochthonous and one allochthonous plant in the flora of Serbia has been done. Four plant taxa are a novelty for proper Serbia, Vojvodina, or Kosovo and Metohija, and for 7 plants, presence in certain administrative units in Serbia has been confirmed. In the last part of the paper, there is a review of 9 disputed taxa for our country.

Key words: vascular flora, checklist, nomenclature, taxonomy, Serbia

\section{INTRODUCTION}

Inventory of the flora of an area represents a comprehensive, long-term and continuous work on recording and reviewing of extremely extensive botanical literature, from the very beginnings of botanical work in some territory, then a critical review of the published data, as well as checking of specimens in herbarium collections. In addition, it is necessary that the taxonomic-nomenclature status of each taxon that is mentioned for a certain territory, corresponds to the latest knowledge in botanical literature.

The beginning of the inventory of the taxa of the vascular flora of Serbia, is related to the period 1993-1995 when a preliminary (internal) list of taxa for the territory of Yugoslavia (later Serbia and Montenegro) was made, based on the review and selection of species and subspecies from the edition of Flora Europaea. The authors of the first list were V. Stevanović, D. Lakušić and M. Niketić, who, on the basis of a complete overview of the taxa, presented the state of diversity of the vascular flora of Yugoslavia, with an overview of species of international significance. Some 10 years later, the Institute for Nature Protection of the Republic of Serbia started the creation of an electronic catalog of the taxa of the vascular flora of Serbia, for the purpose of establishing an information system on protected plants in Serbia. Authors of this electronic catalogue were M. Niketić and G. Tomović, and the names from this catalogue were later taken over for legal regulation and formation of the List of strictly protected and protected plants in the Republic of Serbia as an integral part of the Rulebook on declaration and protection of protected and strictly protected species of plants, animals and fungi (Anonymous 2010-2016).

After 2005, data for updating and inventorying taxa were collected, so that at the beginning of 2018, work on the multi-volume publication "An annotated checklist of vascular flora of Serbia" started. The first volume is planned to include the following groups: Lycopodiopsida, Polypodiopsida, Gnetopsida, Pinopsida and Liliopsida, and the remaining volumes the Magnoliopsida group. Such "An annotated checklist" would integrate all the literature data on the presence of vascular flora taxa in Serbia, and would also include checking of herbarium collections. 
The indispensable basis for publishing of "An annotated checklist of vascular flora of Serbia 1" is the presentation of data on new taxa for the flora of Serbia, whether they are species newly registered for our country or are a confirmation of old and/or inaccurate literary records. In addition, it was also important to show those plant species and subspecies that represent a novelty for individual administrative units in the Republic of Serbia (proper Serbia, Vojvodina, Kosovo and Metohija). The last part of the article is devoted to the erroneously cited or disputed taxa for the territory of Serbia, with comments on which taxon would be treated.

\section{MATERIAL AND METHODS}

Field investigation, identification and revision of herbarium material as well as searching for and checking of numerous literature sources were accomplished in orded to supplement all the floristic and distribution data. Collected plants are deposited in the Herbarium of the Natural History Museum in Belgrade (BEO), Herbarium of the Institute of Botany and Botanical Garden "Jevremovac", University of Belgrade (BEOU), the Herbarium of the Institute for Nature Conservation of the Vojvodina province (PZZP), the Herbarium of Department of Biology and Ecology, Faculty of Sciences, University of Novi Sad (BUNS) (Thiers 2013) and Herbarium of the Faculty of Sciences and Mathematics, Department of Biology and Ecology, University of Niš (HMN).

The names and classification of families and affinity of genera to certain families were given in accordance with PPG I (2016) for ferns and lycopods, Christenhusz et al. (2011) for gymnosperms, and APG IV (2016) for angiosperm families (flowering plants), with certain deviations in the taxa of the highest rank. Nomenclature is given according to the World Check List of selected plant families (WCSP) (http://wcsp.science.kew.org) for Liliopsida (Govaerts et al. 2018). Families, genera and species were sorted in the alphabetical order of their Latin names. Short taxon description for newly registered taxa for Serbia is compiled according to numerous botanical sources, with some changes and modifications which are based on field observations and herbarium specimens inspections.

In the nomenclature notes heterotypic and homotypic names are sorted chronologically. Nomenclatural provisions are applied from ICN (Turland et al. 2018).

Distribution of the plant taxa in the Republic of Serbia is presented according to the grid map with squares of $10 \times 10 \mathrm{~km}$, based on the Military Grid Reference System (MGRS) projection (Lampinen 2001). 
104 Niketić, M. et al.: AnNotated Checklist of Vascular Flora of SERbia I

\section{RESULTS AND DISCUSSION}

\section{Nomenclatural notes}

\section{LILIOPSIDA}

\section{ORCHIDACEAE}

Dactylorhiza saccifera subsp. macrostachys (Tineo) Niketić \& Djordjević, comb. nov.

$\equiv$ Orchis macrostachys Tineo, Pl. Rar. Sicil. (ed. 2): 7 (1846) [basionym] $\equiv$ O. maculata [stat. indet.] macrostachys (Tineo) Asch. \& Graebn., Syn. Mitteleur. Fl. 3: 748 (1907) $\equiv$ Orchis maculata subsp. macrostachys (Tineo) Soó, Repert. Spec. Nov. Regni Veg. 24: 32 (1927), comb. illeg.

$=$ O. gervasiana Tod., Orchid. Sicul.: 57 (1842) $\equiv$ O. maculata var. gervasiana (Tod.) Nyman, Consp. Fl. Eur.: 693 (1882) $\equiv$ D. gervasiana (Tod.) H. Baumann \& Künkele, Mitt. Arbeitskreis Heimische Orchid. Baden-Württemberg 13: 346 (1981) $\equiv D$. saccifera subsp. gervasiana (Tod.) Kreutz, Kompend. Eur. Orchid.: 54 (2004).

$=$ O. bonanniana Tod., Orchid. Sicul.: $57(1842) \equiv$ O. maculata var. bonanniana (Tod.) Nyman, Consp. Fl. Eur.: 693 (1882).

Currently erroneously treated as Dactylorhiza saccifera subsp. gervasiana (Govaerts et al. 2018) with a range limited to S Italy, Sicily and Algeria. According to Art. 11.4. the name D. saccifera subsp. macrostachys actually has priority. These names are often included in the type subspecies in different combinations. For example, records for Serbia and the Balkans in Soó $(1927,1929)$ and Bornmüller (1928) (sub Orchis maculata subsp. macrostachys, comb. illeg.) actually correspond to subsp. saccifera which was erroneously synonymized in Soó (1927, Art. 11.4). It is also included in D. maculata subsp. saccifera (Brongn.) Diklić by Italian authors (G.I.R.O.S. 2009, Bartolucci et al. 2018).

\section{Niketić, V. Djordjević}

Himantoglossum calcaratum subsp. rumelicum (H. Baumann \& R. Lorenz) Niketić \& Djordjević, comb. nov.

$\equiv H$. caprinum subsp. rumelicum H. Baumann \& R. Lorenz, J. Eur. Orch. 37: 945 (2005) [basionym] $\equiv H$. jankae subsp. rumelicum (H. Baumann \& R. Lorenz) J. Ponert, J. Eur. Orch. 46: 563 (2014) $\equiv H$. jankae var. rumelicum (H. Baumann \& R. Lorenz) P. Delforge, Naturalistes Belges 96(Orchid. 28): 16 (2015).

$=H$. caprinum var. heldreichii Schltr., Repert. Spec. Nov. Regni Veg. 15: 287 (1918), syn. nov. $\equiv$ H. calcaratum var. heldreichii (Schltr.) Bornm., 
Bot. Jahrb. Syst. 61(5, Beibl. 140): 123 (1928) $\equiv H$. hircinum var. heldreichii (Schltr.) Soó, Repert. Spec. Nov. Regni Veg. 24: 33 (1927).

=H. jankae Somlyay, Kreutz \& Óvári, Phytotaxa 73: 9 (2012) $\equiv H$. calcaratum subsp. jankae (Somlyay, Kreutz \& Óvári) R. M. Bateman, Molnár \& Sramkó, PeerJ 5(e2893): 69 (2017), comb. illeg.

- "Orchis hircina" sensu Rumy, Vers. ungar. Ärzte Naturfor. 1842: 53 (1846) [non Crantz, Stirp. Austr. Fasc., ed. 2, 2: 484 (1769)]

- "Aceras hircinum" sensu Pančić, Verh. K.K. Zool.-Bot. Ges. Wien 6: 576 (1856) [non (L.) Lindl., Gen. Sp. Orchid. Pl.: 282 (1835)].

- "H. hircinum" sensu Schulzer, Kanitz \& Knapp, Verh. K.K. Zool.-Bot. Ges. Wien 16: 86 (1866) [non (L.) Spreng., Syst. Veg. 3: 694 (1826)]; auct. balc.

- "Himantoglossum hircinum [subsp. caprinum] var. caprinum" sensu Diklić in Josifović (ed.), Flora SR Srbije 8: 79 (1976) [non (M. Bieb.) W. Zimm., Allg. Bot. Z. Syst. 23: 11 (1917)].

incl. H. calcaratum ["subsp. jankae"] var. robustissimum (Somlyay, Kreutz \& Óvári) R. M. Bateman, Molnár \& Sramkó, PeerJ 5(e2893): 70 $(2017) \equiv H$. caprinum subsp. robustissimum Kreutz, J. Eur. Orch. 38: 122 (2006). $\equiv H$. jankae subsp. robustissimum (Kreutz) Kreutz, Ber. Arbeitskreis. Heimische Orchid. 31: 119 (2015).

Presented nomenclature is based on taxonomic concept and comprehensive study on intricate hircinum-caprinum clade in Bateman et al. (2017). The only correction applied is concerning illegitime combination Himantoglossum calcaratum subsp. jankae in that paper. In the revised classification list (Appendix 2) authors included two combinations with the final epithet "rumelicum" in the synonymy but without the basionym, $H$. caprinum subsp. rumelicum, which represent the earliest legitimate name of the taxon at subspecific rank. However, basionym (of $H$. c. subsp. rumelicum) is mentioned and cited in table 6 . and pag. 60 that technically makes their new combination illegitimate (Art. 11.4). At the "World Checklist of Selected Plant Families" (WCSP) (Govaerts et al. 2018) H. caprinum subsp. rumelicum (described from the Balkans) is recognized as a current taxon. This seems unlikely, because according to Bateman et al. (2017) distribution range of $H$. caprinum is limited to Crimea and Anatolia and epithet "rumelicum" is included in Balkan-Anatolian H. calcaratum ["subsp. jankae"] which is also accepted as a current subspecies in Govaerts et al. (2018).

A second novelty in presented nomenclature is the inclusion of $H$. caprinum var. heldreichii, which is omitted in Bateman et al. (2017). The same plant is interpreted as H. hircinum var. hircinum in Govaerts et al. 
(2018). However, H. caprinum var. heldreichii was described from the Balkan Peninsula ("Griechenland, Serbien") (Schlechter 1918), whereas $H$. hircinum complex is limited to $\mathrm{C}$ and $\mathrm{W}$ Europe and $\mathrm{W}$ Mediterranean (Bateman et al. 2017). Proposed type specimen at the "Global Plants database" [https://plants.jstor.org/stable/10.5555/al.ap.specimen.g00096463 ?searchUri=filter\%3Dname\%26so\%3Dps_group_by_genus_species\%2Bas c\%26Query\%3D\%2528Himantoglossum\%2Bcaprinum\%2529] is certainly inadequate. That specimen, originally identified as Aceras caprina, was collected in Crimea (Novyi Sad village ["Neusatz"] near Simferopol, 1899) by Max Wetschky and does not have any connection with the protologue.

The type subspecies of $H$. calcaratum is found in W Serbia and Kosovo and Metohija, whereas H. c. subsp. rumelicum is distributed in central and eastern parts of the country.

M. Niketić, V. Djordjević

Ophrys sphegodes subsp. taurica (Aggeenko) Soó ex Niketić \& Djordjević, comb. nov.

[Soó, Acta Bot. Acad. Sci. Hung. 5(1-2): 444 (1959), comb. inval.].

$\equiv$ O. aranifera var. taurica Aggeenko, Scripta Bot. Horti Univ. Petrop. 1: 291 (1886) [basionym] $\equiv$ O. atrata var. taurica Schmalh., Fl. Sredn. Jushn. Rossii 2: $460(1897) \equiv$ O. aranifera subsp. taurica (Aggeenko) K. Richt., Pl. Eur. 1: 263 (1890) $\equiv$ O. aranifera [subsp. atrata] f. taurica (Aggeenko) Soó, Bot. Arch. 23: 28 (1928) $\equiv$ O. taurica (Aggeenko) Nevski in V. L. Komarov (ed.), Fl. URSS 4: 728 (1935) $\equiv$ O. mammosa subsp. taurica (Aggeenko) Soó, Feddes Repert. 85: 446 (1974).

$=$ O. mammosa Desf., Ann. Mus. Hist. Nat. 10: $222(1807) \equiv$ O. aranifera var. mammosa (Desf.) Rchb. f. in Rchb., Icon. Fl. Germ. Helv. 13-14: 89 $(1851) \equiv$ O. aranifera subsp. mammosa (Desf.) Soó, Notizbl. Bot. Gart. Berlin-Dahlem 9: 907 (1926) $\equiv$ O. sphegodes subsp. mammosa (Desf.) Soó ex E. Nelson, Gestaltw. Artb. Orchid. Eur. Mittelmeerl.: 184 (1962) [Soó, Izv. Bot. Inst. (Sofia) 6: 370, comb. inval.].

$=O$. sintenisii H. Fleischm. \& Bornm., Ann. Naturhist. Mus. Wien 36: 10 $(1923) \equiv$ O. sphegodes subsp. sintenisii (H. Fleischm. \& Bornm.) E. Nelson, Gestaltw. Artb. Orchid. Eur. Mittelmeerl.: 181 (1962) $\equiv O$. transhyrcana subsp. sintenisii (H. Fleischm. \& Bornm.) Kreutz, Kompend. Eur. Orchid.: 119 (2004).

$=$ O. transhyrcana Czerniak., Bot. Mater. Gerb. Glavn. Bot. Sada R.S.F. S.R. 4: 1 (1923) $\equiv$ O. aranifera subsp. transhyrcana (Czerniak.) Soó, Repert. Spec. Nov. Regni Veg. Sonderbeih. A 2: 49 (1931) $\equiv O$. sphegodes subsp. transhyrcana (Czerniak.) Soó, Acta Bot. Acad. Sci. Hung. 5(1-2): 444 (1959) $\equiv$ O. mammosa subsp. transhyrcana (Czerniak.) Buttler, Willdenowia 16: 115 (1986). 
$=$ O. aranifera subsp. macedonica H. Fleischm. ex Soó, Repert. Spec. Nov. Regni Veg. 24: 27 (1927) $\equiv$ O. macedonica (H. Fleischm. ex Soó) Devillers-Tersch. \& Devillers, Naturalistes Belges 75(7, Suppl.): 381 (1994) $\equiv$ O. mammosa subsp. macedonica (H. Fleischm. ex Soó) Kreutz, Kompend. Eur. Orchid.: 107 (2004).

$=$ O. aranifera f. hymettii Soó, Repert. Spec. Nov. Regni Veg. 24: 27 (1927).

= O. mammosa var. boissieri Soó, Repert. Spec. Nov. Regni Veg. 24: 35 $(1927) \equiv$ O. aranifera var. boissieri (Soó) Soó, Bot. Arch. 23: 28 (1928) $\equiv$ O. aranifera subsp. boissieri (Soó) Soó, Repert. Spec. Nov. Regni Veg. 26: 279 (1929) $\equiv$ O. sphegodes subsp. boissieri (Soó) Soó, Acta Bot. Acad. Sci. Hung. 5(1-2): 444 (1959), comb. inval.

$=$ O. aranifera var. vierhapperi Soó, Repert. Spec. Nov. Regni Veg. 24: 55 (1927) $\equiv$ O. mammosa subsp. vierhapperi (Soó) Soó, Acta Bot. Acad. Sci. Hung. 18: 380 (1973).

$=$ O. spruneri var. orientalis Soó, Repert. Spec. Nov. Regni Veg. Sonderbeih. A 1: 112 (1927).

$=O$. aesculapii subsp. pseudaranifera Renz, Repert. Spec. Nov. Regni Veg. 25: 250 (1928).

= O. pseudomammosa Renz, Repert. Spec. Nov. Regni Veg. 25: 262 (1928).

$=$ O. caucasica Woronow in A. A. Grossheim, Fl. Kavkaza 1: 261 (1928) $\equiv$ O. mammosa subsp. caucasica (Woronow) Soó, Acta Bot. Acad. Sci. Hung. 18: 383 (1973).

= O. adonidis A. Camus \& Gomb., Notul. Syst. (Paris) 14: 104 (1951).

$=$ O. turcomanica Renz, Fl. Iranica 126: 85 (1978).

$=$ O. sphegodes subsp. parnassica Soó ex J. J. Wood, Orchidee (Hamburg) 31: 233 (1980) [Soó, Acta Bot. Acad. Sci. Hung. 5(1-2): 444 (1959), comb. inval.].

$=O$. transhyrcana subsp. amanensis E. Nelson ex Renz \& Taubenheim, Notes Roy. Bot. Gard. Edinburgh 41: 271 (1983) [O. sphegodes subsp. amanensis E. Nelson, Gestaltw. Artb. Orchid. Eur. Mittelmeerl.: 182 (1962), nom. inval.] $\equiv O$. amanensis (E. Nelson ex Renz \& Taubenheim) P. Delforge, Naturalistes Belges 72: 101 (1991).

$=O$. mammosa subsp. grammica B. Willing \& E. Willing, Mitt. Arbeitskreis Heimische Orchid. Baden-Württemberg 17: 523 (1985) $\equiv O$. grammica (B. Willing \& E. Willing) Devillers-Tersch. \& Devillers, Naturalistes Belges 72: 101 (1991) $\equiv$ O. sphegodes subsp. grammica (B. Willing \& E. Willing) Kreutz, Kompend. Eur. Orchid.: 116 (2004).

$=$ O. mammosa subsp. serotina B. Willing \& E. Willing, Mitt. Arbeitskreis Heimische Orchid. Baden-Württemberg 17: 525 (1985). 
$=O$. herae M. Hirth \& H. Spaeth, Mitt. Arbeitskreis Heimische Orchid. Baden-Württemberg 24: 6 (1992) $\equiv$ O. sphegodes subsp. herae (M. Hirth \& H. Spaeth) Kreutz, Kompend. Eur. Orchid.: 116 (2004).

$=$ O. caucasica subsp. cyclocheila Aver., Bot. Zhurn. (Moscow \& Leningrad) 79(10): 124 (1994) $\equiv$ O. mammosa subsp. cyclocheila (Aver.) B. Baumann, H. Baumann, R. Lorenz \& Ruedi Peter, J. Eur. Orch. 35: 172 $(2003) \equiv$ O. cyclocheila (Aver.) P. Delforge, Naturalistes Belges 85: 252 (2004).

$=$ O. leucophthalma Devillers-Tersch. \& Devillers, Naturalistes Belges 75(7, Suppl.): 380 (1994) $\equiv$ O. mammosa subsp. leucophthalma (Devillers-Tersch. \& Devillers) Kreutz, Kompend. Eur. Orchid.: 107 (2004).

$=$ O. hittitica Kreutz \& Ruedi Peter, J. Eur. Orch. 30: 128 (1997).

$=$ O. hystera Kreutz \& Ruedi Peter, J. Eur. Orch. 30: 128 (1997).

$=$ O. antalyensis Kreutz \& Seckel in C. A. J. Kreutz, Orchid. Türkei: 752 $(1998) \equiv$ O. amanensis subsp. antalyensis (Kreutz \& Seckel) Kreutz, Kompend. Eur. Orchid.: 80 (2004).

$=$ O. iceliensis Kreutz, J. Eur. Orch. 32: 529 (2000) $\equiv$ O. amanensis subsp. iceliensis (Kreutz) Kreutz, Kompend. Eur. Orchid.: 80 (2004).

$=O$. alasiatica Kreutz, Segers \& H. Walraven, J. Eur. Orch. 34: 480 $(2002) \equiv$ O. sphegodes subsp. alasiatica (Kreutz, Segers \& H. Walraven) H. Baumann \& R. Lorenz, J. Eur. Orch. 37: 728 (2005).

$=O$. janrenzii M. Hirth, Jahresber. Naturwiss. Vereins Wuppertal 55: 171 $(2002) \equiv$ O. herae subsp. janrenzii (M. Hirth) M. Hirth, J. Eur. Orch. 37: $176(2005) \equiv$ O. sphegodes subsp. janrenzii (M. Hirth) Kreutz, Orchidee (Hamburg) 57: 101 (2006) $\equiv$ O. mammosa subsp. janrenzii (M. Hirth) Kreutz, Ber. Arbeitskreis. Heimische Orchid. 24(1): 177 (2007) $\equiv O$. herae f. janrenzii (M. Hirth) P. Delforge, Naturalistes Belges 88: 251 (2008).

$=$ O. morio Paulus \& Kreutz, Orchid. Zypern: 415 (2004) $\equiv$ O. transhyrcana subsp. morio (Paulus \& Kreutz) Kreutz, Kompend. Eur. Orchid.: 119 (2004).

$=$ O. mammosa subsp. mouterdeana B. Baumann \& H. Baumann, J. Eur. Orch. 37: $263(2005) \equiv$ O. transhyrcana subsp. mouterdeana (B. Baumann \& H. Baumann) Kreutz, Eurorchis 17: 110 (2005) $\equiv O$. mouterdeana (B. Baumann \& H. Baumann) P. Delforge, Naturalistes Belges 96(Orchid. 28): 18 (2015) $\equiv$ O. doerfleri subsp. mouterdeana (B. Baumann \& H. Baumann) Paulus \& M. Hirth, J. Eur. Orch. 49: 253 (2017).

$=$ O. mammosa subsp. falsomammosa B. Baumann \& H. Baumann, J. Eur. Orch. 37: 725 (2005) $\equiv$ O. mammosa f. falsomammosa (B. Baumann \& H. Baumann) P. Delforge, Naturalistes Belges 88: 251 (2008). 
$=$ O. mammosa subsp. posteria B. Baumann \& H. Baumann, J. Eur. Orch. 37: 726 (2005) $\equiv$ O. posteria (B. Baumann \& H. Baumann) Devillers \& Devillers-Tersch., Naturalistes Belges 93: 162 (2012).

$=$ O. transhyrcana subsp. paphlagonica Kreutz, Ber. Arbeitskreis. Heimische Orchid. 24(1): 119 (2007) $\equiv$ O. paphlagonica (Kreutz) P. Delforge, Naturalistes Belges 96(Orchid. 28): 18 (2015).

$=O$. hansreinhardii M. Hirth, J. Eur. Orch. 39: 474 (2007).

$=$ O. cretensis subsp. samica A. Alibertis, J. Eur. Orch. 43: 754 (2011).

$=O$. herae subsp. osmaniaca Kreutz, Ber. Arbeitskreis. Heimische Orchid. 28: 279 (2011) $\equiv$ O. osmaniaca (Kreutz) P. Delforge, Naturalistes Belges 96(Orchid. 28): 18 (2015).

= O grammica subsp. knossia A. Alibertis, Orchidophile (Asnières) 191: $285(2011) \equiv O$. knossia (A. Alibertis) P. Delforge, Naturalistes Belges 93: 242 (2012).

= O. mammosa subsp. parviflora Kreutz \& H. Heitz, Ber. Arbeitskreis. Heimische Orchid. 29: 149 (2013).

=O. mammosa subsp. ciliciana Kreutz, Ber. Arbeitskreis. Heimische Orchid. 30: 275 (2013) $\equiv$ O. ciliciana (Kreutz) P. Delforge, Naturalistes Belges 96(Orchid. 28): 17 (2015).

$=$ O. chaonica P. Delforge, Naturalistes Belges 96(Orchid. 28): 17 (2015).

$=O$. willingii Paulus \& M. Hirth, J. Eur. Orch. 49: 270 (2017).

= O. prespaensis M. Hirth \& Paulus, J. Eur. Orch. 49: 284 (2017).

Presented nomenclature follows Govaerts et al. (2018) with the exception of the current name (Ophrys sphegodes subsp. mammosa in Govaerts et al. 2018) which is replaced with $O$. s. subsp. taurica in accordance with Art. 11.4. Its basionym is validly published with a full description (Aggeenko 1886) and the first use of the final epithet at subspecific rank was in the combination $O$. aranifera subsp. taurica (Richter 1890). Although author of this combination was not explicitly indicated ranks of taxa, they can be inferred from the summary table in the introductory part of the book ("54" "subspecies" in "Orchidaceae").

The new combination (O. s. subsp. taurica) was previously applied in Soó (1959) but with no full reference to a basionym and therefore did not fulfill all conditions to be valid (Art. 41.5).

The type subspecies of $O$. sphegodes is sporadically distributed in most regions of Serbia, whereas $O$. $s$. subsp. taurica is only known from one locality in southeastern part of the country. Last subspecies was represented in the Red Data Book of Flora of Serbia (Randjelović \& Zlatković 1999) as O. mammosa. 


\section{Floristic notes}

\section{New and confirmed taxa for the flora of Serbia}

\section{POLYPODIOPSIDA}

\section{ASPLENIACEAE}

Asplenium microphyllum Tineo in Gussone, Fl. Sicul. Syn. 2: 884 (1845). = A. trichomanes subsp. inexpectans Lovis, Brit. Fern Gaz. 9: 155 (1964).

This diploid fern belongs to the complex Asplenium trichomanes which also includes diploid (A. trichomanes L.) and tetraploid species $[A$. quadrivalens (D. E. Mey.) Landolt (=A. t. subsp. quadrivalens D. E. Mey.), A. csikii Kümmerle \& András. (= A. t. subsp. pachyrachis (Christ) Lovis \& Reichst.)] in Serbia. According to Liu et al. (2018) phylogenetic plastid DNA analysis supports the argument that the mentioned taxa have to be in a rank of species. However, authors erroneously used the name $A$. inexpectans (Lovis) Landolt, although it does not have priority over $A$. microphyllum.

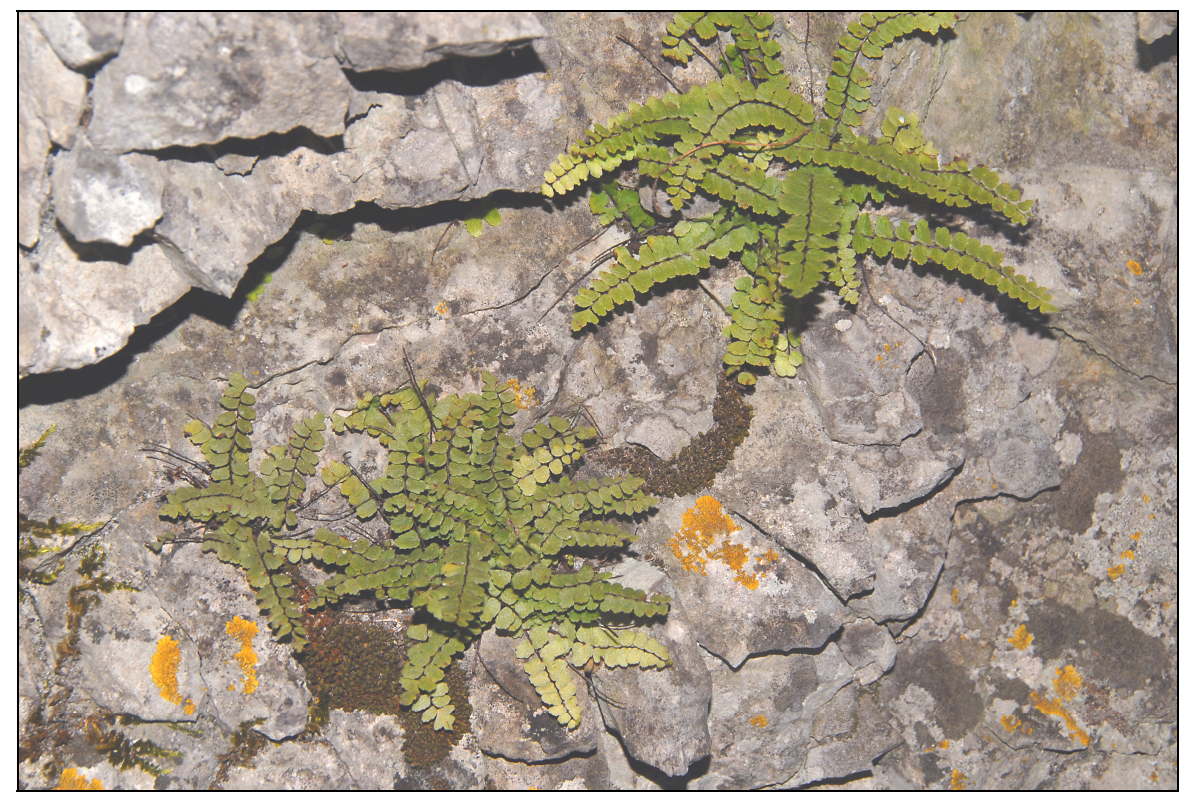

Fig. 1. - Asplenium microphyllum Tineo (Vratna Gorge).

It has the following characteristics. Rhizome shallow, easily pulled out from the substrate. Fronds 6-12 (25) cm long, usually strongly arcuated, generally appressed to the substrate. Lamina 4-9(12-20) cm long, linearlanceolate, abruptly contracted to an obtuse or subacute apex, with 1018(25) pairs of weak and soft, pinnae; medium pinnae slightly distant or imbricate, 4-8(10) $\mathrm{mm}$ long, subquadrate to oblongo-rectangular, usually 
incised to lobed; margin convex at least on the long sides, \pm crenate; lower surface of lamina sometimes with small, light glands ending with an orange cell; stomata 30-45 $\mu \mathrm{m}$; upper pinnae slightly smaller, $0-1.5(2) \mathrm{mm}$ apart, \pm opposite, perpendiculary inserted to the rachis; terminal 4-7 mm wide. Rachis weak; scales about $3.5 \mathrm{~mm}$ long, with a dark brown midrib. Annulus after dehiscence of sporangium usually bent. Spores (25)28-36(42) $\mu \mathrm{m}$ long. $2 \mathrm{n}=72$.

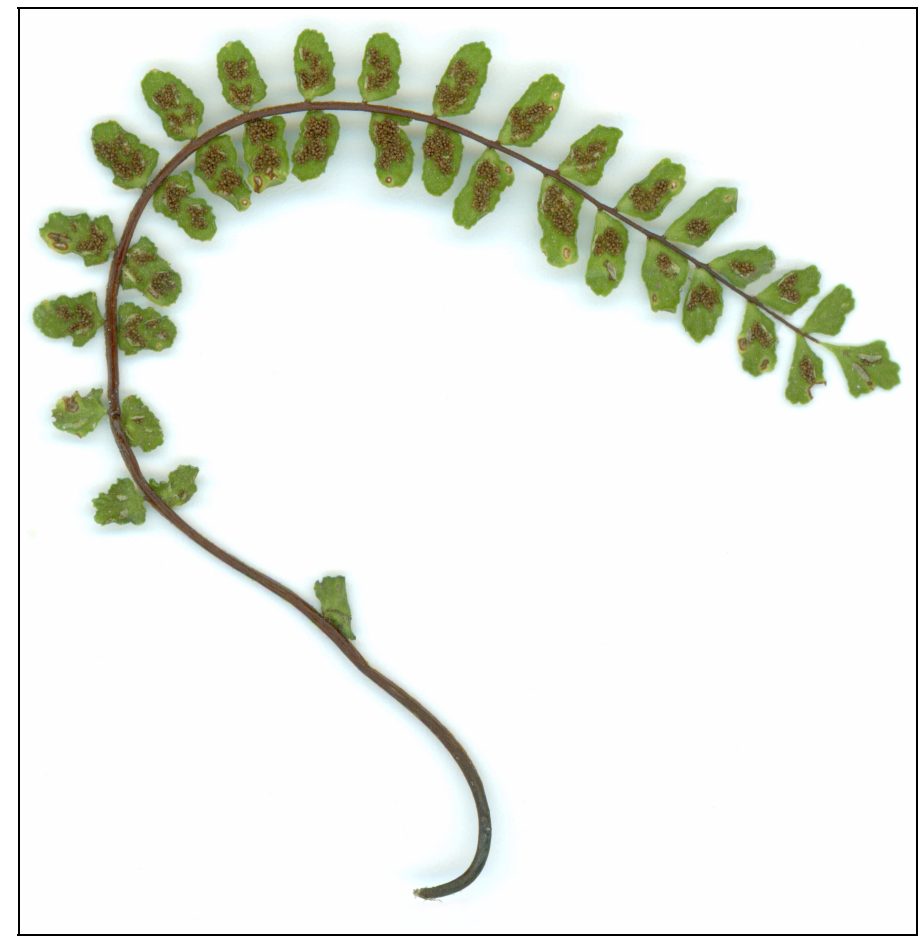

Fig. 2. - Asplenium microphyllum Tineo

(Vratna Gorge, BEO 82873) - Frond.

In comparison to other species from the group, it is characterized by shallow rhizome and relatively large upper and terminal pinnae. Together with $A$. csikii, it differs from $A$. trichomanes and A. quadrivalens in its small stature, strongly arcuated fronds appressed to the substrate, lamina not tapering towards the apex, as well as in smaller number of perpendiculary inserted and \pm imbricate pinnae (however they are distant in the herbarium specimens). Unlike A. csikii (which is reported from Kosovo and Metohija) it has also smaller stomata and spores, arcuate lamina (vs. arcuate to sinusoidal) and crenate and not distinctly bright margin of the pinnae. Form of the piannae varies significantly within the species range. Observed individuals from the new recorded population in NE Serbia (Vratna Gorge) are characterized by slighty incised to entire pinnae. 


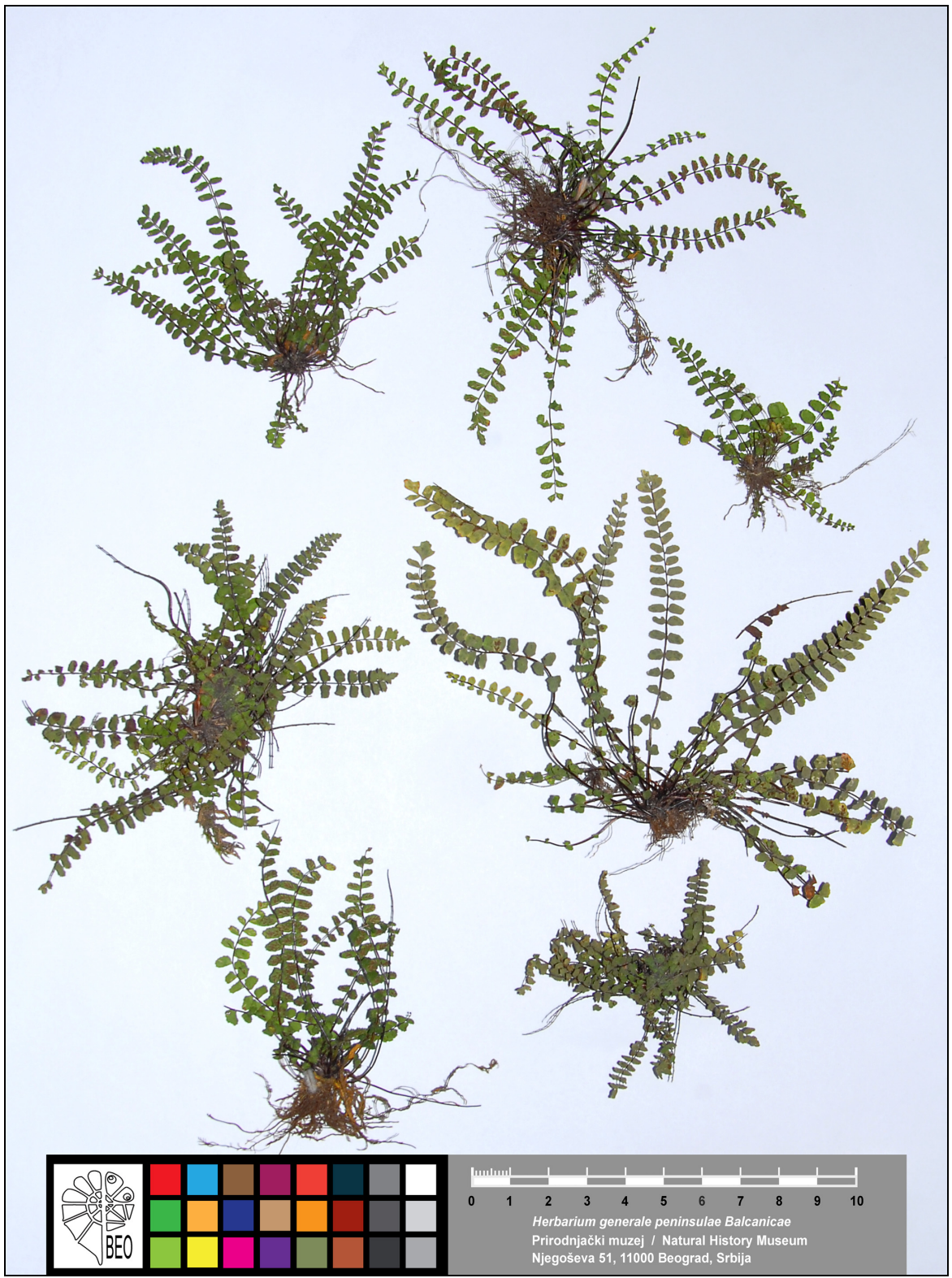

Fig. 3. - Asplenium microphyllum Tineo (NE Serbia, Vratna Gorge, BEO 82873).

This plant is distributed in (sub)Mediterranean (from NE Spain and SE France to Italy, Croatia and Greece) and $\mathrm{C}$ and E Europe (from Austria, Czech, Slovakia, to Ukraine and Russia) with an isolated locality on Gotland in S Sweden (Christenhusz \& Raab-Straube 2013). It inhabits rock crevices on limestone, usually on cliffs. In the habitat in NE Serbia, ca. fifty 
individuals are restricted to cliffs and cavities on bare limestone surface (Fig. 1). They are nested within more larger population of $A$. quadrivalens. The measured spores were significantly smaller than those of A. quadrivalens (from the same locality), corresponding the size in diploid representatives of the group.

\section{First record:}

NE Serbia, Vratna Gorge, $300 \mathrm{~m}$ upstream from Velika Kapija, 185 m, limestone crevices, $22.3335843^{\circ} \mathrm{E}, 44.3837304^{\circ} \mathrm{N}$, MGRS 34T FQ01, coll. M. Niketić 15-Nov-2018 (BEO 82873) (Figs. 2-3, 19).

A new species for the flora of Serbia.

M. Niketić

Asplenium quadrivalens (D. E. Mey.) Landolt, Fl. Indicativa: 268 (2010). $\equiv$ A. trichomanes subsp. quadrivalens D. E. Mey., Ber. Deutsch. Bot. Ges. 74: 456 (1962).

Also belongs to the Asplenium trichomanes complex. It has the following set of characters. Rhizome deep, not easily pulled out from the substrate. Fronds up to 25(35) cm long, erect or slightly arcuate, not appressed to the substrate. Lamina up to $25(35) \mathrm{cm}$ long, linear-lanceolate, tapering towards the apex, with 10-33 pairs of asymmetrical pinnae; medium pinnae distant, rarely overlaping, $3.5-11 \mathrm{~mm}$ long, oblongo-rectangular, with the entire or crenate convex margin; lower surface of lamina with brownish scales or glabrous; stomata $42-63 \mu \mathrm{m}$. Upper pinnae significantly smaller, 2.5-3.5(4) $\mathrm{mm}$ apart, \pm opposite, oblique or perpendiculary inserted to the rachis; terminal 1-3(4) mm wide. Rachis thick to relatively weak; scales about $5 \mathrm{~mm}$ long, with a dark brown midrib; wings with distinctly enlarged yellow orange papillae. Annulus 200-300 $\mu \mathrm{m}$ in diameter; after dehiscence of sporangium usually stretched. Spores (32)34-42(50) $\mu \mathrm{m}$ long. $2 \mathrm{n}=144$.

Although until now it has not been recorded for Serbia, it occurs widely and represent the most abundant species in A. trichomanes group. This tetraploid is closely related and hardly distinguished from diploid $A$. trichomanes which is present in mountainous silicate areas. Diagnostic features are relatively larger and less distant upper pinnae, which are \pm opposite, oblongo-rectangular medium pinnae (vs. suborbicular to ovate) with convex margin (vs. concave), longer scales and papillae on the rachis, smaller ring and larger stomata and spores. The majority of specimens in $\mathrm{BEO}$ and BEOU, identified as $A$. trichomanes, actually belong to $A$. quadrivalens.

It is distributed in whole Europe, Macaronesia (Christenhusz \& RaabStraube 2013), Africa, Asia, N America, Pacific Islands, Australia and New 
Zealand (Wagner et al. 1993). Usually grows in rock crevices, rocky walls, screes, stony hillside forests, rotten woods, from the lowlands to the alpine belt. Indifferent to the substrate, but prefers light to shady mossy places on limestone and avoid vertical cliffs. In the Vratna Gorge (NE Serbia) it coexists with related A. microphyllum which occupies shady cliffs and cavities on the surface with little or no moss.

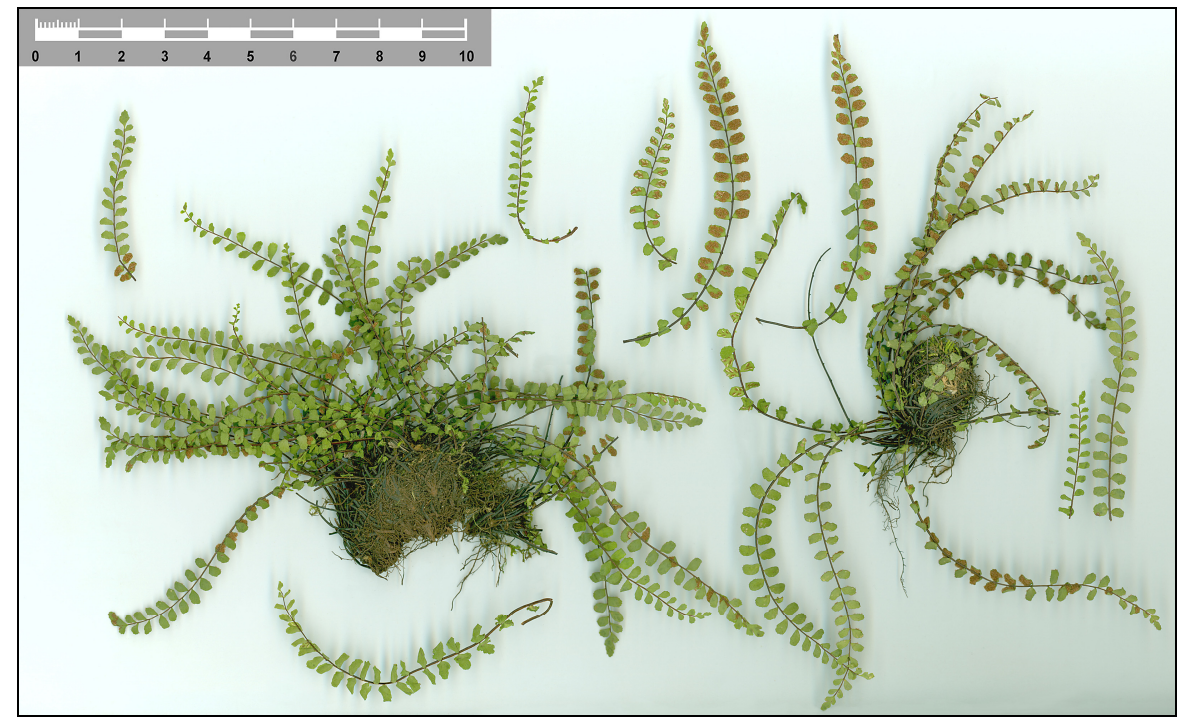

Fig. 4. - Asplenium quadrivalens (D. E. Mey.) Landolt (NE Serbia, Vratna Gorge, BEO 82874).

First record:

NE Serbia, Vratna Gorge, $300 \mathrm{~m}$ upstream from Velika Kapija, $185 \mathrm{~m}$, limestone crevices, $22.3335843^{\circ} \mathrm{E}, 44.3837304^{\circ} \mathrm{N}$, MGRS 34T FQ01, coll. M. Niketić 15-Nov-2018 (BEO 82874) (Fig. 4).

A new species for the flora of Serbia.

M. Niketić

\section{EQUISETACEAE}

Equisetum $\times$ moorei Newman, Phytologist 5: 19 (1854).

$[=E$. hyemale $\times$ E. ramosissimum $]$

By its general appearance this nothospecies is closely resembling to $E$. hyemale but its stems are as a rule annual (not over-wintering as in $E$. hyemale), rather slender, long attenuated and less sulcate (10-20 grooves vs. up to 30 grooves in $E$. hyemale), the sheats are clearly longer than broad, loose, sometimes almost completely whitish. Teeth of leaf-sheats are largely persistent (or only partly evanescing), ending with fragile, elongate, scarious brown to brown-whitish awns (in E. hyemale teeth of leaf-sheats 


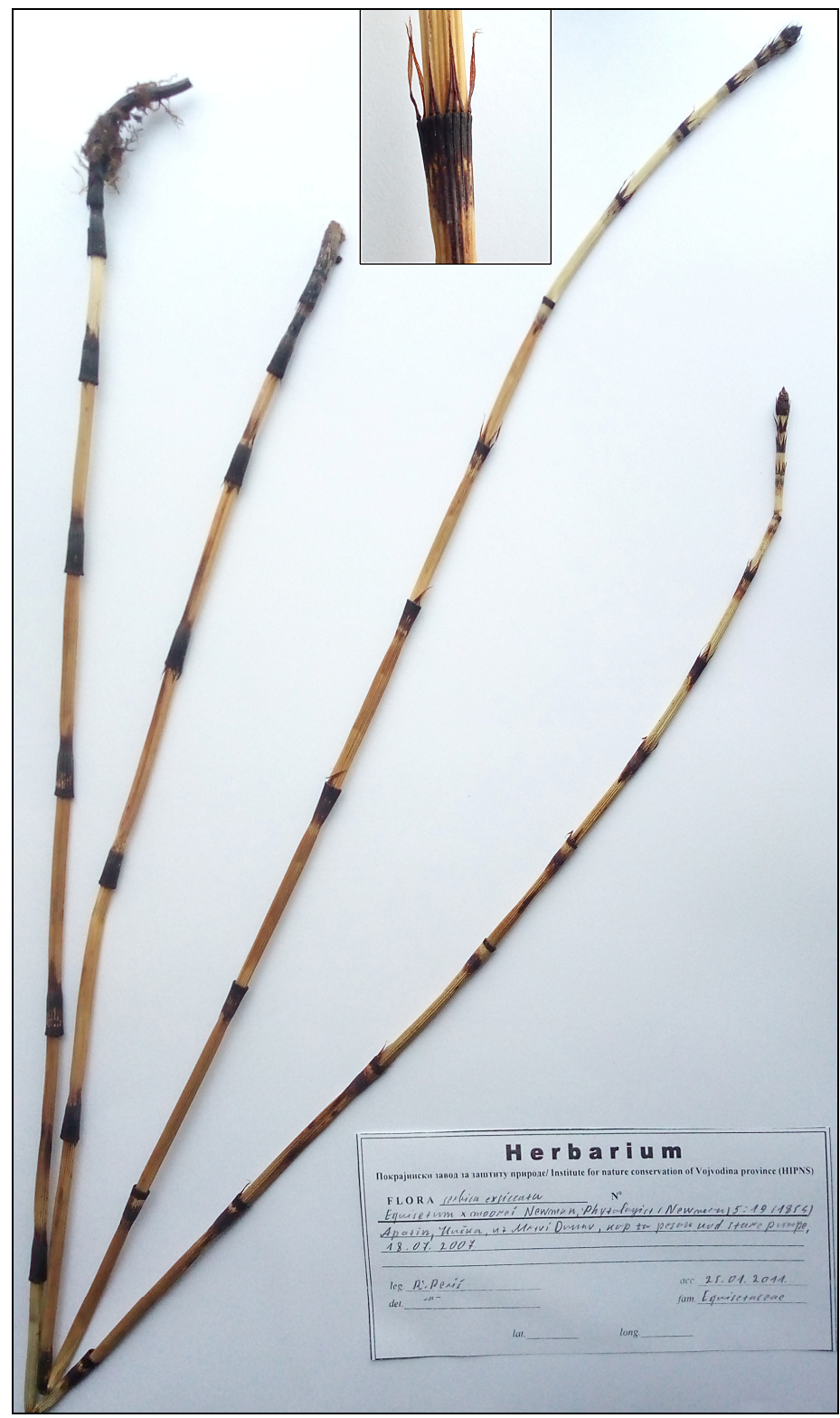

Fig. 5. - Equisetum $\times$ moorei Newman - Apatin (Kučka) (s.n. PZZP).

are short and caducous). Also, the stem in $E$. $\times$ moorei is never branching as is the case with $E$. ramosissimum or hyemale $\times E$. variegatum hybrids. Described from Ireland (Newman 1854). Published data suggests that the most of its areal covers W, NW and parts of C Europe, while its presence in $\mathrm{SE}$ and $\mathrm{E}$ Europe appears to be more sporadic or even questionable (Kalinowski et al. 2016). It is reported from Portugal, Spain (Prada 1986), 
the British Isles (Stace 2010), France (Tison \& Foucault 2014), Belgium (Bizot \& Pétrement 2010), Luxembourg (Bizot et al. 2012), the Netherlands (Winter \& Lubienski 2012), Germany (Lubienski 2011), Italy (Lucchese 2008), Czech (Kubát et al. 2002), Slovakia (Futák 1966), Hungary (Simon 2000), Romania (Grinţescu 1952), Sweden (Mossberg \& Stenberg 2003), Poland (Kalinowski et al. 2016), Latvia, Estonia (Laasimer et al. 1993), Russia and Kazakhstan (Kalinowski et al. 2016). In the Balkans it had been discovered in Bulgaria where it was found in numerous localities (Hájek et al. 2005). Although it was listed for the flora of Serbia too (Vukićević 1970, 1992) data about its presence were given without precise locality.

Its typical habitats are sandy river banks and lake shores, mostly on granular substrates (Page 1990, Hájek et al. 2005).

New record:

Bačka, Apatin, Kučka, near old pumping station, abandoned sand mine, MGRS 34T CR36, coll. et det. R. Perić 18-Jul-2007 (s.n. PZZP) (Figs $5,19)$.

Confirmed hybrid for the flora of Serbia.

R. Perić

\section{PINOPSIDA}

\section{CUPRESSACEAE}

Platycladus orientalis (L.) Franco, in Portugaliae Acta Biol., Sér. B, Sist. 1949: 33 (1949).

$\equiv$ Thuja orientalis L., Sp. Pl.: 1002 (1753).

Previous data concerning this E Asiatic species in the Flora of SR Serbia (Jovanović 1970 sub Thuja orientalis) and Flora of Serbia (Jovanović 1992 sub $T$. orientalis) relate only to cultivated ornament plants. First occurrence of the plant in natural habitats was unofficially mentioned (Niketić 1986) for E Serbia (Jelašnica Gorge in vicinity of Niš). Species was reported as subspontaneous in very exposed rocky places and several individuals have survived to this days. Plant also has been found and monitored at the nearby location Koritnik near Niška Banja. It was also sporadically observed (probably as casual alien) at some other (usually urban) localities in Serbia and these habitats should be better investigated.

\section{First records:}

E Serbia, Niš, Jelašnica Gorge.

Niška Banja (Koritnik) MGRS 34T EN99, M. Niketić (field observ.).

First records of the species in natural habitats in Serbia. 


\section{Niketić}

\section{LILIOPSIDA}

\section{JUNCACEAE}

Juncus $\times$ diffusus Hoppe, Flora (Regensburg) 2(12): 186 (1819), cf. Tab. CDXIV in Reichenbach, Icon. Fl. Germ. Helv. 9 (1847). [=J. effusus $\times$ J. inflexus $]$

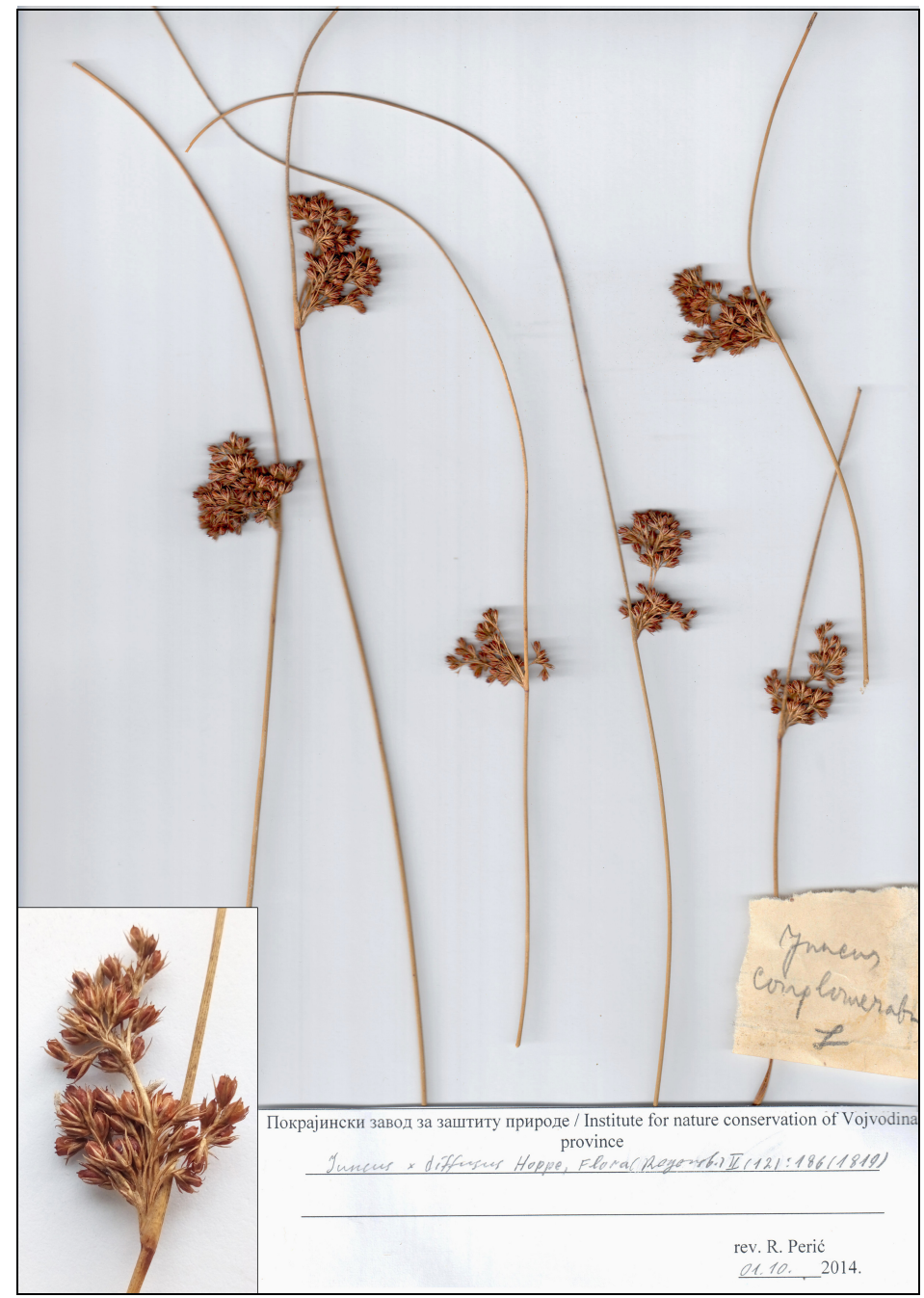

Fig. 6. - Juncus ×diffusus Hoppe - Bačka, Sombor, Bački Monoštor (s.n. PZZP).

Prima facice this plant looks like less glaucous and somewhat taller form of $J$. inflexus with similarly ridged stem, lax inflorescence and lanceolate-linear, acuminate perianth-segments, but the ridges on the stem 
are sometimes irregular and usually more numerous (25-49 compared to 10-20 in J. inflexus), pith is continuous (as in J. effusus, while in J. inflexus is interrupted), anthers are usually poorly developed, capsule is strikingly obovate, more obtuse, ending with short mucro and usually shorter than perianth (i. e. more similar to J. effusus while in $J$. inflexus capsule is trigonous-ovoid or trigonous-ellipsoid, mostly acute and exceeding, or rarely equaling perianth) (Hoppe 1819, Snogerup 1980, Kirschner 2002, Wilcox 2010). Described from Germany. Its distribution is poorly known with records from south Scandinavia, C Europe and Algeria (Kirschner 2002). It usually develops on damp, open habitats among the parents, where it forms large and long-lived tussocks (Kirschner 2002).

\section{First record:}

Bačka, Sombor, Bački Monoštor, MGRS 34T CR37, coll. et det. N. Babić 15-Jun-1954 (sub J. conglomeratus L.), rev. R. Perić (s.n. PZZP) (Figs 6, 19).

A new hybrid for the flora of Serbia.

R. Perić

Luzula fallax Kirschner, Preslia 63(2): 84 (1991).

The plant is very similar to the species Luzula multiflora (Ehrh.) Lej. and L. taurica (V. I. Krecz.) Novikov, from which it can be distinguished by small papillae on the peduncles. In Serbia, it is known only from Mt Stol in NE Serbia, near the town of Bor. According to Bačić et al. (2016) samples from Mt Stol are similar to L. fallax in papillose peduncles and karyotype (agmatoploid with ca. 24 half-sized chromosomes), but have relatively ovoid-subglobular seeds with very long caruncle, similar to $L$. campestris (L.) DC. or L. divulgata Kirschner, and relatively short anthers and styles like L. multiflora. The same authors also noticed that the true identity of the plant from Mt Stol has not been established yet, and it is possible that it is actually a hybrid that originates from L. fallax. In the meantime, several herbarium sheets from different periods of development were found in BEO from the same locality. After reviewing this material, it was concluded that morphological properties of that samples fit into the description of L. fallax given by Kirschner (1991) and significantly differs from L. campestris and L. divulgata.

\section{First record:}

NE Serbia, Mt. Stol, source part of the Luka River ("Lučka reka"), right side, MGRS 34T EP99, coll. et det. V. Nikolić 22-Jun-1955 (sub L. campestris subsp. vulgaris), rev. M. Niketić 27-Mar-2018 (BEO 82875) (Figs 7, 19). 
NE Serbia, Mt. Stol, Luka River ("Lučka reka"), left side, exp. SW, MGRS 34T EP99, coll. V. Nikolić, N. Diklić, det. N. Diklić (sub $L$. campestris subsp. multiflora), rev. M. Niketić 27-Mar-2018 (BEO 82876).

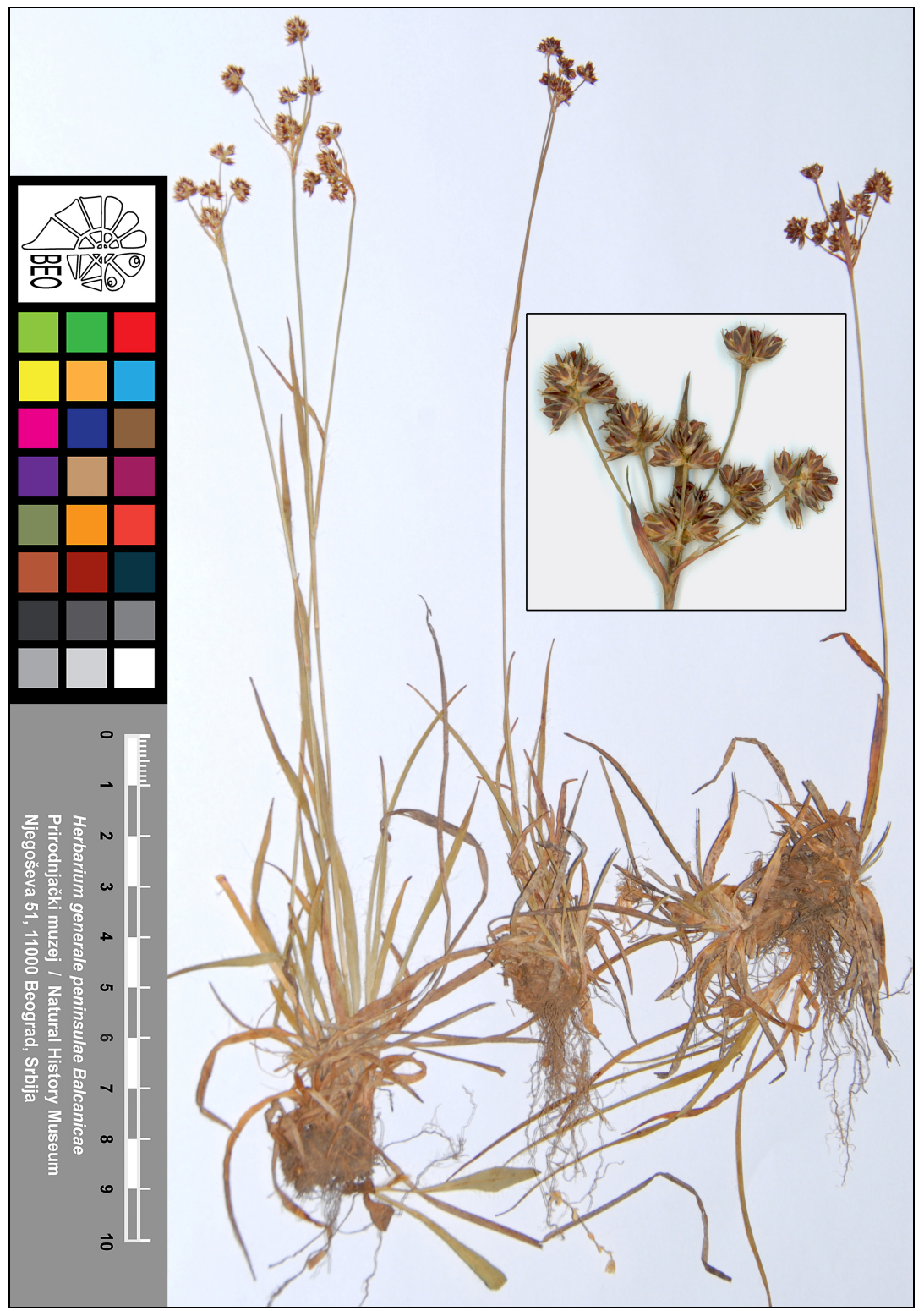

Fig. 7. - Luzula fallax Kirschner (NE Serbia, Mt. Stol, BEO 82875).

NE Serbia, Mt. Stol, Luka River ("Lučka reka"), right side, MGRS 34T EP99, coll. V. Nikolić, N. Diklić 28-Jul-1962, det. N. Diklić (sub L. 
campestris subsp. multiflora), rev. M. Niketić 27-Mar-2018 (BEO 82876).

A new species for the flora of Serbia.

M. Niketić

\section{LILIACEAE (AMARYLLIDACEAE)}

Allium lusitanicum Lam., Encycl. [J. Lamarck \& al.] 1(1): 70 (1783).

Anačkov (2009) cited this species for Mts. Prokletije on the basis of inspection of herbarium material found in Herbarium collection of the Natural History Museum in Belgrade (BEO).

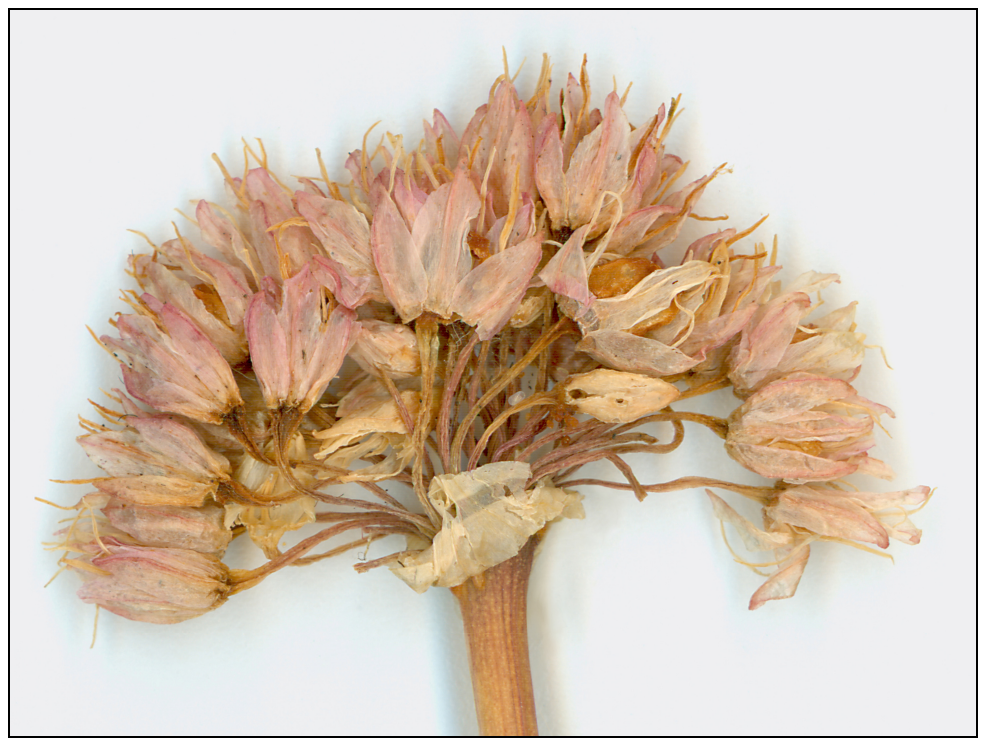

Fig. 8. - Allium lusitanicum Lam. (Mts. Prokletije, Mt Koprivnik, BEO 27990). Inflorescence.

Highly disjunct distribution of the Eurasian species A. lusitanicum is a consequence of its specific habitat preferences. Namely, the species occurs exclusively in mountains at high elevations. In the Flora of Serbia this species was cited for two localities: Sićevačka Gorge in E Serbia and Panjak in W Serbia (Tatić 1975 sub A. montanum F. W. Schmidt). However, the species was not found on these localities after the analysis of habitat types and field surveys. On the basis of inspection of herbarium material (BEO), data from Mts. Prokletije was confirmed, while localities from the flora of Serbia (Tatić 1975) were designated as doubtful. Also, since A. lusitanicum does not grow in Vojvodina, the data referred in the literature from the territory of Vojvodina (Vajgand 1965 - BUNS; Obradović \& Panjković 1980, Čapaković 1983, Obradović \& PanjkovićMatanović 1988) represent erroneous identifications. 


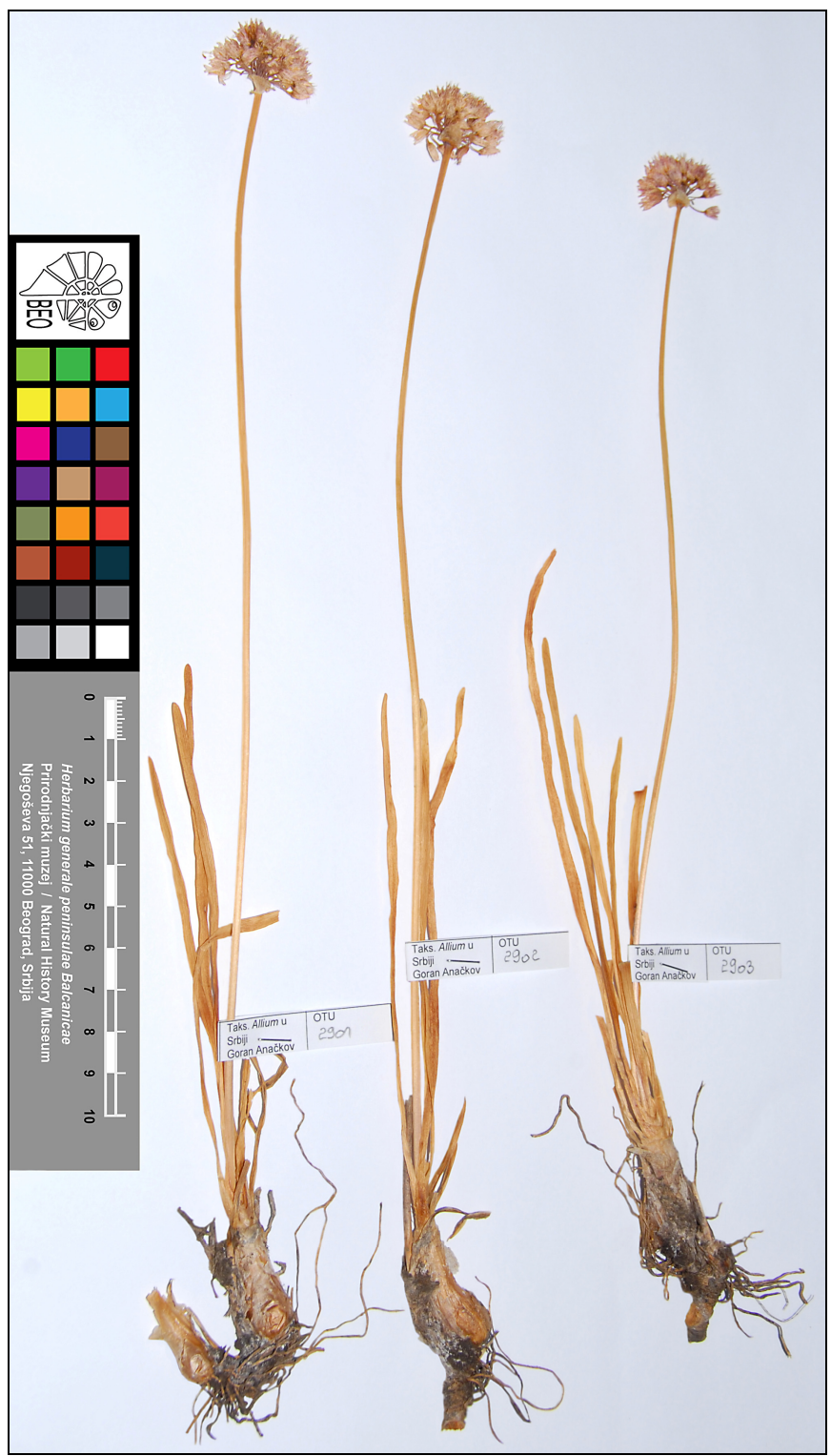

Fig. 9. - Allium lusitanicum Lam. (Mts. Prokletije, Mt

First record:

Koprivnik, BEO 27990).

Metohija, Mts. Prokletije, Mt Koprivnik, MGRS 34T DN31, DN32, coll. P. Černjavski Aug-1934, det. P. Černjavski 1940 (sub A. montanum), rev. G. Anačkov 22-Aug-2008 (BEO 27990) (Figs. 8-9, 19). A new species for the flora of Serbia. 
Allium sphaerocephalon subsp. arvense (Guss.) Arcang., Comp. Fl. Ital.: 702 (1882).

Allium sphaerocephalon subsp. arvense is a representative of the infraspecific group of the species A. sphaerocephalon, which is characterized by pale green or almost completely white flowers. However, the only

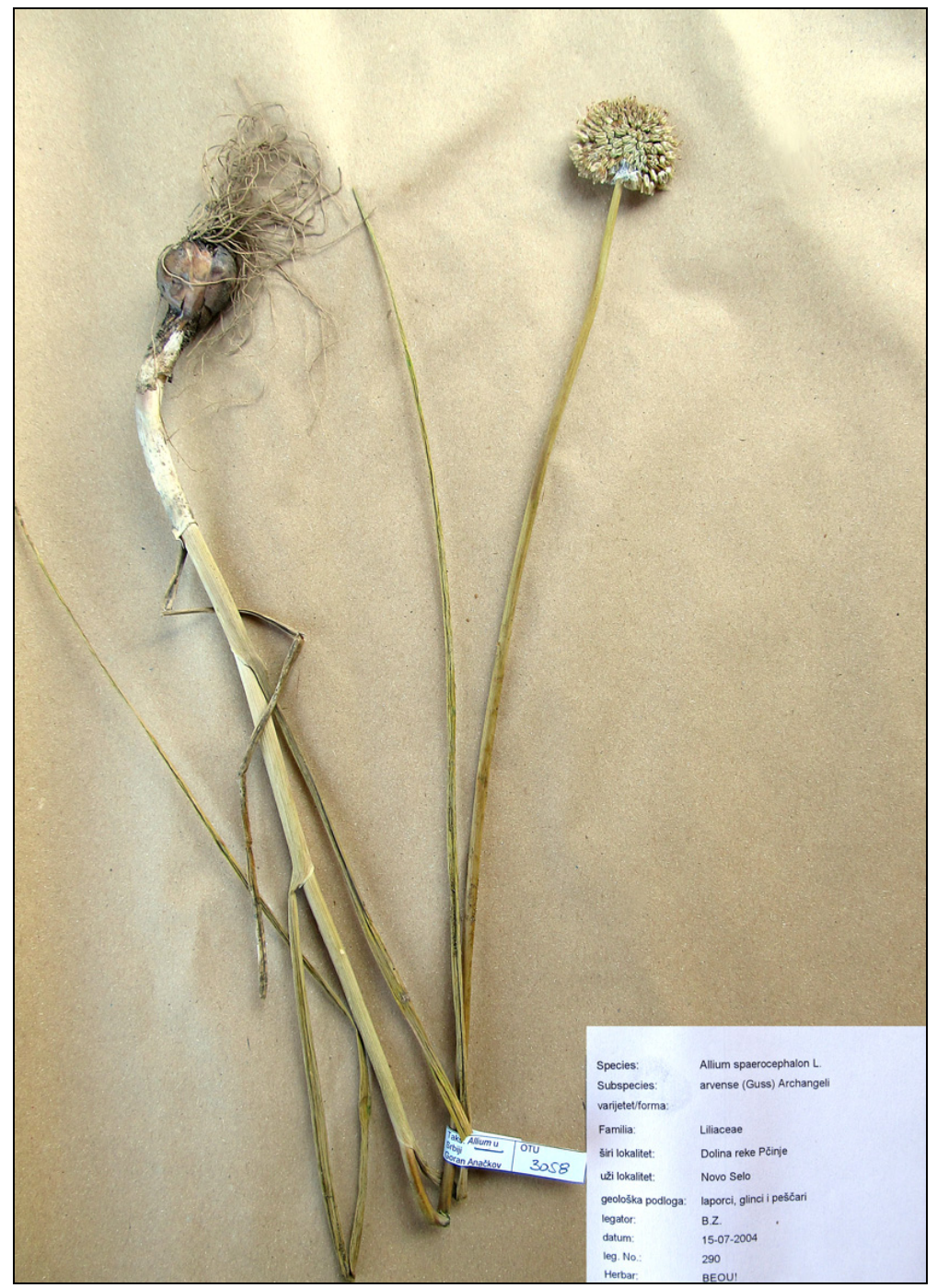

Fig. 10. - Allium sphaerocephalon subsp. arvense (Guss.) Arcang. (Pčinja River Valley, Novo Selo) 290 BEOU.

character that distinguish subspecies arvense from the typical subspecies is a flower colour, which significantly makes it proper identification difficult, and especially because during the late summer months on steppe habitats, 
bright pink or red perigone of the typical subspecies slowly fading, while prominent green nerves remaining on sepals only. This taxon has emphasized E Mediterranean distribution, but it is recorded in Malta and Sicily, as well as in the northern parts of Africa (Mathew 1996).

In Serbia, it was found in only on two localities (near Vogance and Novo Selo villages) in the Pčinja River Valley on thermophilic and xerophilous habitats. These records were previously unofficially mentioned in Anačkov (2009) and Zlatković (2011).

\section{First records:}

SE Serbia, Pčinja River Valley, Novo Selo village, dry grasslands on carbonate (Festuca valesiaca formation), marl, clay and sandstone, 530 m, MGRS 34T EM89, coll. B. Zlatković 15-Jul-2004, det. G. Anačkov (290 BEOU) (Figs 10, 19).

SE Serbia, Pčinja River Valley, Vogance village, dry grasslands and bedrocks on silicate (Koelerio-Silenetum friwaldskyanae), fine-grained biotite and biotite-muscovite gneiss, $440 \mathrm{~m}$, MGRS 34T EM78, coll. B. Zlatković, M. Jušković 28-Jun-2004, det. G. Anačkov (1071 BEOU).

A new subspecies for the flora of Serbia.

G. Anačkov, B. Zlatković

\section{LILIACEAE (ASPARAGACEAE)}

Asparagus acutifolius L., Sp. Pl. 1: 314 (1753).

This Mediterranean plant was only known from Kosovo and Metohija province. It was found by Košanin (1939) in Prizren, Krasniqi (1972) in Mt Paštrik (Gorožup village) and by Janković (1982) in Mts. Šar-Planina, while in the Flora of SR Serbia it was not mentioned (Vukićević \& Diklić 1975).

\section{New record:}

Metohija, Prizren, Beli Drim Gorge, Našec, MGRS 34T DM77, (B. Zlatković, Jul-1995, field observation).

Confirmed species for the flora of Serbia.

\section{B. Zlatković}

\section{LILIACEAE (COLCHICIACEAE)}

Colchicum doerfleri Halácsy, Denkschr. Kaiserl. Akad. Wiss., Wien. Math.-Naturwiss. K1. 64: 742 (1897).

Colchicum doerfleri is spring-flowering species with synanthous leaves, appearing at the same time with flowers. This endemic species is distributed in southern part of the Balkan Peninsula including Albania, Bulgaria, Greece, Macedonia (Malo \& Shuka 2013) and S Serbia, recently 
also reconsidered for Croatia (Milović 2017). It is most similar with $C$. hungaricum Janka growing in $\mathrm{W}$ Balkans and Hungary, while it was previously treated as a synonym of that species (Brickell 1980). According to the recent literature, $C$. doerfleri is separate species distinguished from $C$. hungaricum in densely hairy outer leaf side and more intense flower color (Milović 2017, Persson 2007). In Serbia C. doerfleri occurs in dry grasslands, as well as among shrubs on limestone, silicate and ultramafite substrates. It usually inhabits south exposed, sandy or stony slopes in the belt of termophilous oak forests, growing together with following species: Clinopodium alpinum subsp. hungaricum (Simonk.) Govaerts, Astragalus onobrychis L., Leontodon biscutellifolius DC., Phleum montanum K. Koch, Melica ciliata L., Hypericum olympicum L., Trifolium trichopterum Pančić, Koeleria macrantha (Ledeb.) Schult., Silene frivaldszkyana Hampe etc.

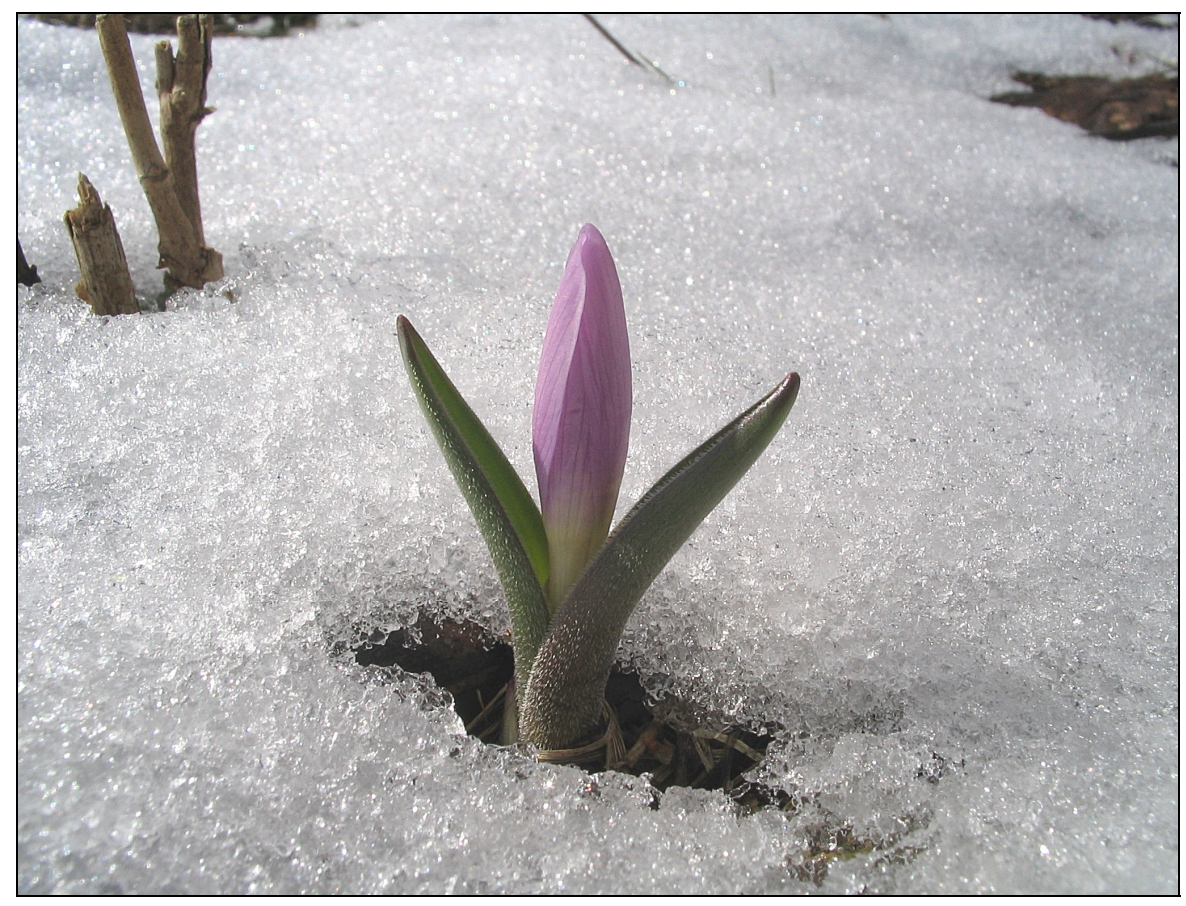

Fig. 11. - Colchicum doerfleri Halácsy - plant from Mt Starac in SE Serbia (photo B. Zlatković).

Ranđelović (1984) was the first botanist who found this Balkan endemic plant in Mt Rujan and near Preševo settlement (village Trnava) in $\mathrm{S}$ Serbia. However, he published it under the name C. hungaricum Janka. This record was also cited by Ranđelović et al. (1986 sub C. hungaricum Janka) from the neighbour localities: Mt Rujan (Mamince and Cer villages) and Mt Skopska Crna Gora (village Trnava) (Fig. 19). 


\section{First records:}

SE Serbia, Mt Starac, Karaula, thermophilous shrubby formation (Ostryo-Carpinion aegeicum), fine-grained biotite and biotite-muscovite gneiss, $436 \mathrm{~m}$, MGRS 34T EM78, coll. et det. B. Zlatković 03-Mar2000 (BEOU, coll. No. 2272) (Figs 11, 19).

S Serbia, Mt Rujan, Veliki Orljak, Slavujevac, MGRS 34T EM68, coll. M. Stanković 2015, det. B. Zlatković (s.n. HMN) (Fig. 19).

Species represents a new taxon for the flora of Serbia, replacing erroneously reported C. hungaricum in this area.

B. Zlatković

\section{LILIACEAE (LILIACEAE)}

Fritillaria messanensis subsp. neglecta (Parl.) Nyman, Consp. Fl. Eur.: 721 (1882).

- "F. gracilis" sensu Hayek, Akad. Wiss. Wien, Math.-Naturwiss. Kl., Denkschr. 99: 215 (1924) [non (Ebel) Asch. \& Graebn., Syn. Mitteleur. Fl. 3: 192 (1905)]; auct.

Subspecies belongs to Apennine-Balkan Fritillaria messanensis Raf. which also includes: $F$. m. subsp. messanensis (distributed in Peloponnese and Mt Olimbos in Greece and Calabria and Sicily in S Italy), F. m. subsp. gracilis (Ebel) Rix (reported for Montenegro, Albania, Calabria in S Italy and the Ionian Islands in Greece) and F. m. subsp. sphaciotica (Gand.) Kamari \& Phitos (endemic to Crete in Greece) (Kamari \& Phitos 2006, Tomović et al. 2007, Peruzzi et al. 2009, 2017, Dimopoulos et al. 2013, Barina et al. 2018).

By morphological properties, this subspecies is the most similar to $F$. $m$. subsp. gracilis, and in all likelihood tessellation appears sporadically in both subspecies, with the latter being less common in $F$. $m$. subsp. neglecta. The fascias are almost always present in $F$. $m$. subsp. neglecta, while sporadically occurring in $F$. $m$. subsp. gracilis. In addition to the above, there are some other characters that are important for the morphological differentiation of the subspecies.

Almost all literature records for the flora of Serbia were published under the name $F$. gracilis (Ebel) Asch. \& Graebn. (Hayek 1924, Jávorka et al. 1926, Markgraf 1932, Diklić 1975, Nikolić et al. 1986). According to, at that time, current classification, Tomović et al. (2007) recognized this taxon at subspecific rank as $F$. m. subsp. gracilis (Ebel) Rix and presented its distribution in Serbia (Kosovo and Metohija province). Soon after, Peruzzi et al. (2009) re-evaluated neglected $F$. neglecta Parl. in subspecific rank, F. m. subsp. neglecta, separating NW Balkan populations (coastal 
mountains in Croatia: Istria and Dalmatia) from the rest of the $F$. $m$. subsp. gracilis (described from SE Montenegro). Kranjčev \& Šešok (2016) and Vuksanović et al. (2016) considered that $F$. m. subsp. neglecta is also present in Istria Peninsula, Dinaric mountains, Pelješac Peninsula and Korčula Island in Croatia, as well as in mountainous regions of W, E and N Montenegro, whereas $F$. $m$. subsp. gracilis is limited to Mediterranean and Submediterranean parts of Croatia and Montenegro. The lattermost subspecies is locally distributed along the Adriatic coast and hinterland, from Konavle in southeastern Dalmatia (Croatia) to Mt Rumija at the border of Montenegro and Albania. On the basis of inspection of numerous herbarium and photo material, it can be concluded that Konavle and Mt Orjen (SE Croatia, SW Montenegro and SE Bosnia and Hercegovina) actually represents a single parapatric contact zone between these ecologically segregated subspecies. Barina et al. (2018) also listed both subspecies for the flora of Albania. Older literature data for the presence of $F . m$. subsp. gracilis in other parts of Dalmatia, as well as for southeastern Dinarides in Hercegovina, Montenegro, Serbia (Kosovo and Metohija) and N Albania (Mts Prokletije or North Albanian Alps), actually refers to $F . m$. subsp. neglecta.

\section{First records:}

Metohija, Mts. Prokletije, vicinity of Peć, MGRS 34T DN32, coll. Sobrijevski 1933, det. P. Černjavski (sub. F. tenella), rev. M. Niketić 08-Nov-2006 (sub. F. messanensis subsp. gracilis), second rev. M. Niketić 26-Mar-2010 (BEO 28156) (Fig. 12a).

Metohija, Mts. Prokletije, Mt Mokra Planina, above Kaličane village, Krš Bogotija karst, MGRS 34T DN43, coll. I. Rudski 30-Jun-1932, det. N. Diklić (sub F. gracilis), rev. M. Niketić 26-Mar-2010 (BEO 39671) (Fig. 12b).

Metohija, Mt Mokra Gora, Vrelski Potok, 1300-1400 m, MGRS 34T DN53, coll. I. Rudski 02-Jul-1932 (sub F. gracilis), rev. M. Niketić 26Mar-2010 (39670 BEO).

Metohija, Mts. Prokletije, Mt Streočke Planine, Krš Čalis, limestone, MGRS 34T DN31, coll. et det. M. Niketić 23-Aug-1997 (sub F. messanensis subsp. gracilis), rev. M. Niketić 26-Mar-2010 (s.n. BEO).

Metohija, Mts. Prokletije, Rugovska Gorge, MGRS 34T DN32, coll. I. Rudski 27-Apr-1937, det. N. Diklić (sub F. tenella MB.), rev. M. Niketić 26-Mar-2010 (s.n. BEO).

Metohija, Mts. Prokletije, below the top of Mt Nedžinat, rocks in the subalpine region, limestone, MGRS 34T DN22, coll. P. Černjavski, I. Rudski, V. Lintner 28-Jul-1933, det. P. Černjavski (sub F. tenella), rev. M. Niketić 26-Mar-2010 (28160 BEO). 


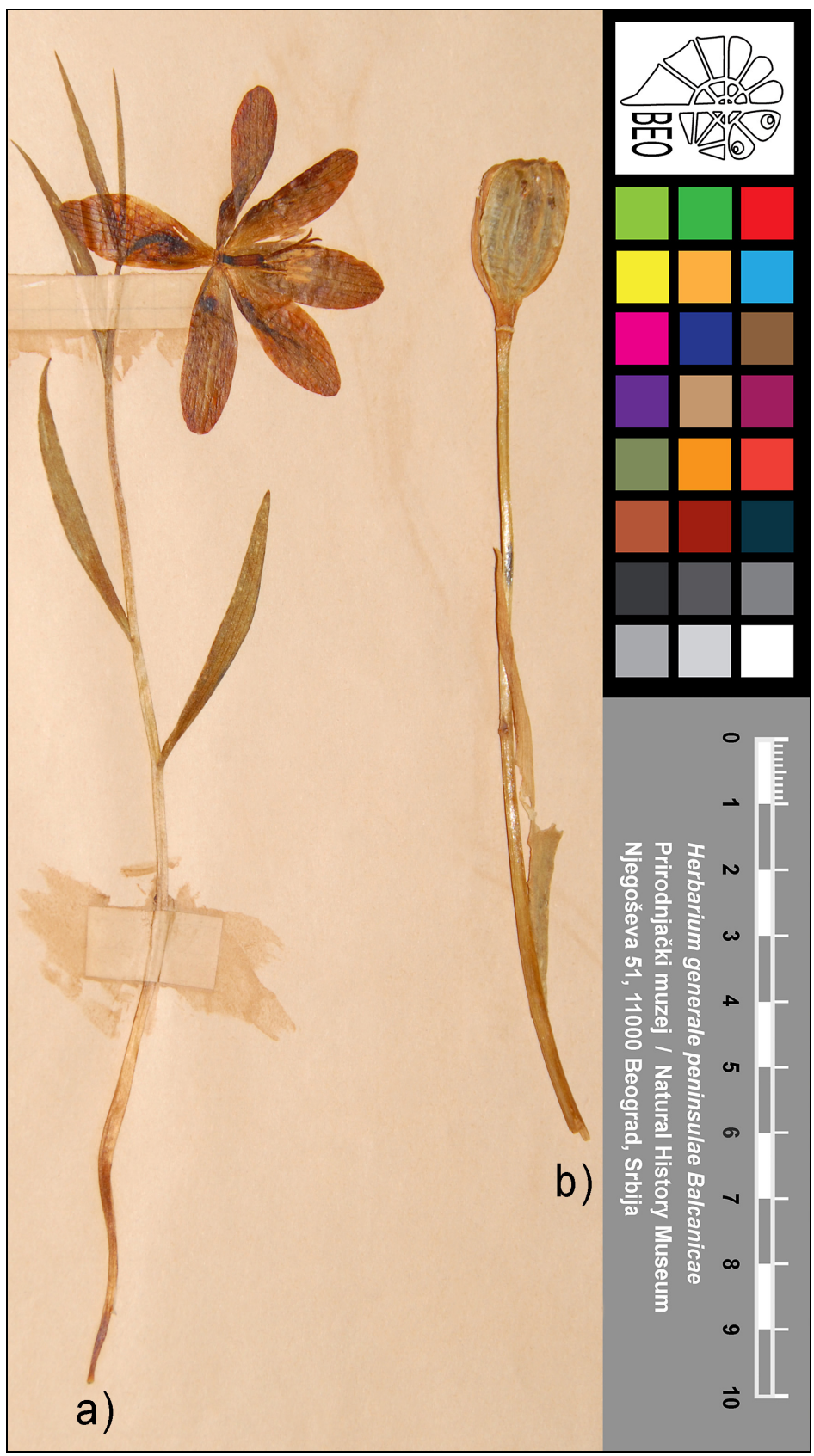

Fig. 12. - Fritillaria messanensis subsp. neglecta (Parl.) Nyman (Metohija, Mts. Prokletije: a) BEO 28156, b) BEO 39671).

Subspecies represents a new taxon for the flora of Serbia, replacing erroneously reported $F$. $m$. subsp. gracilis in this area. 


\section{ORCHIDACEAE}

Anacamptis laxiflora (Lam.) R. M. Bateman, Pridgeon \& M. W. Chase, Lindleyana 12(3): 120 (1997).

This taxon was cited in the literature only at the specific rank for the flora of Serbia (Diklić 1976). Because it had previously included Anacamptis (Orchis) palustris as a subspecies, it is impossible to know whether the authors believed it was this specific taxon or their allegations actually related to $A$. palustris (which is more likely). Boué (1840) was the first botanist who mentioned this species for Serbia, but without precise locality. Grisebach (1846) mentioned it for the vicinity of Kruševac city and Pančić (1865) for the surroundings of Belgrade. Additionally, Pančić (1874) listed this species in the Flora of the Principality of Serbia, with a morphological description that corresponds to this taxon. Adamovic (1908) published that this species grows on Mts. Stara Planina, while according to Soó (1929), the only Serbian specimen that somewhat corresponds to this species originated from vicinity of the town of Aleksinac, but this specimen was morphologically also quite similar to $A$. palustris subsp. elegans.

The distribution of this Atlantic-Submediterranean species in Serbia is still insufficiently known, since it was mentioned for Vojvodina province only by Schulzer et al. (1866) for Bukovac, and this old literature record should be checked in the field. In the Flora of SR Serbia (Diklic 1976) it is mentioned as sporadically distributed, and the only precise localities are surroundings of Dečani and Uroševac in Kosovo and Metohija province (Nikolić et al. 1986).

\section{New record:}

S Serbia, Bujanovac, surroundings of Nesalce village, wet meadows along the highway E75, $408 \mathrm{~m}$, MGRS 34T EM59, coll. et det. B. Radak 20-May-2016 (s.n. BUNS).

Confirmed orchid species for the flora of Serbia.

B. Radak

\section{POACEAE (GRAMINEAE)}

Agrostis gigantea Roth, Tent. Fl. Germ. 1: 31 (1788) subsp. gigantea

It was firstly published for Vojvodina province by Rumy (1846 sub $A$. sylvatica Host) for the town of Sremski Karlovei as well as by Schulzer et al. (1866 sub A. vulgaris var. sylvatica Gaudin) for the region of Srem.

In the Flora of SR Serbia it was published for vicinity of Aranđelovac (Garaši village) by Cincović \& Kojić [1976 sub A. alba var. sylvatica (Asch. \& Graebn.) Cinc. \& Kojić]. Guelmino [1968 sub A. alba subsp. 
gigantea (Roth) Jirasek] reported one new locality near Senta settlement in Vojvodina province.

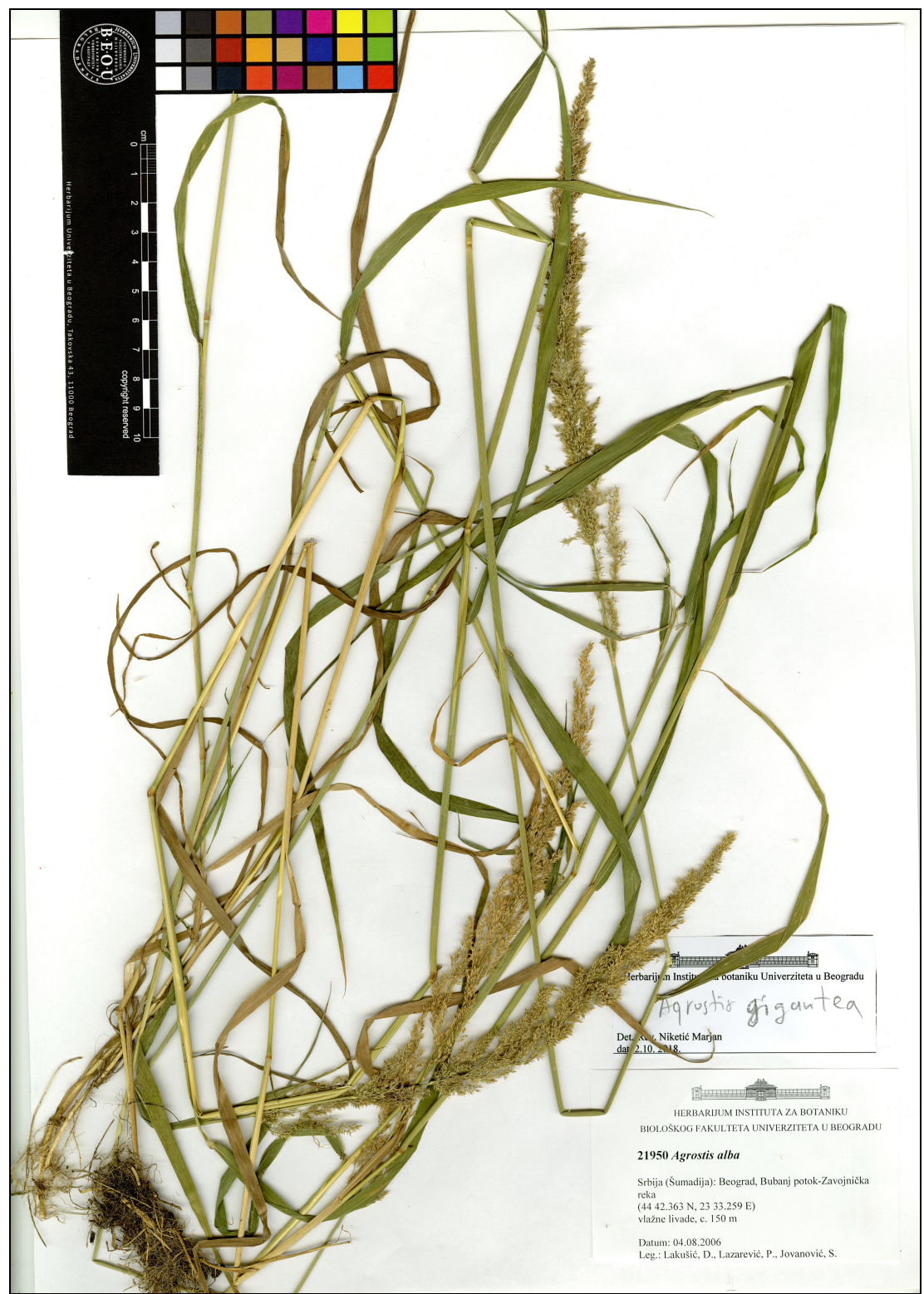

Fig. 13. - Agrostis gigantea Roth (Šumadija, Beograd, Bubanj Potok) 21950 BEOU.

Zlatković (2011) previously unofficially reported this species for Pčinja River valley in SE Serbia. Herbarium samples from Vojvodina, W Serbia and vicinity of Belgrade have been also found (PZZP, BUNS, BEOU). 
New records:

SE Serbia, Pčinja River Valley, Šajince village, shrubby communities on gravel deposits, Salici amplexicaule-Myricarietum, alluvium, $540 \mathrm{~m}$, MGRS 34T EM89, coll. B. Zlatković, V. Ranđelović 19-Sep-2006, det. B. Zlatković (1976 BEOU).

Šumadija, Beograd, Bubanj Potok, Zavojnička River, 150 m, 20.55431 E, 44.70605 N, MGRS 34T DQ65, wet meadows, coll. et det. D. Lakušić, P. Lazarević, S. Jovanović 04-Aug-2006 (A. alba), rev. M. Niketić 02Oct-2018 (21950 BEOU) (Fig. 13).

Banat, Deliblato Sands, N. Babić 04-Sep-1954, det. N Jogan (s.n. PZZP). Srem, Šid, Berkasovo-Bapska, coll. P. Boža 21-Sep-1978, det. N Jogan (s.n. BUNS).

Bačka, Novi Sad, coll. anonym. 07-Aug-1974, det. N Jogan (s.n. BUNS). W Serbia, Mt Mučanj, Katići: Zijača-Ljeskova glava, along the river Mali Rzav, MGRS 34T DP13 coll. et det. R. Perić 06-Aug-2008 (sub A. stolonifera var. sylvatica), rev. N. Jogan (Dec-2017) (s.n. PZZP).

Confirmed species for the flora of Serbia.

B. Zlatković, M. Niketić, N. Jogan

Cenchrus longispinus (Hack.) Fernald, Rhodora 45: 388 (1943).

Allochthonous species originating from warm temperate, subtropical and tropical areas of $\mathrm{N}$ and $\mathrm{C}$ America and the Carribean (Verloove \& Sánchez Gullón 2012). It was introduced in numerous countries surrounding the Mediterranean and the Black Sea (Valdés et al. 2009). In Europe it had been widely and repeatedly confused with similar but less widespread species $C$. spinifex Cav., from which it differs by the presence of numerous (30-50) and long ["longispinus!'] involucral spines on spikelets (in $C$. spinifex spikelets have about 20-30 shorter spines). Furthermore, in $C$. longispinus the inner spines of spikelets are only slightly flattened while the outer (lowermost) spines are usually bristle-like compared to $C$. spinifex, where the inner spines are strikingly flattened at the base (up to $3 \mathrm{~mm}$ ) and the bristle-like outer spines are often missing (Verloove \& Sánchez Gullón 2012). In the Balkans C. longispinus is known from Greece and Croatia (ibidem). In Serbia it was erroneously published for Vojvodina province (Subotica-Horgoš Sands), under the name $C$. incertus M. A. Curtis and apparently without supporting herbarium specimens (Obradović et al. 1984, Obradović \& Boža 1985, Obradović 1986, Obradović \& Boža 1986, Obradović \& Panjković-Matanović 1986, Stevanović et al. 2009, Lazarević et al. 2012).

The species was discovered in 2008. on sandy disturbed grounds and fallows along the border with Hungary in the vicinity of Subotica and Bački 
Vinogradi, where it was abundantly present as noxious weed. The closest next record is situated in the Kiskunság National Park (Verloove \&

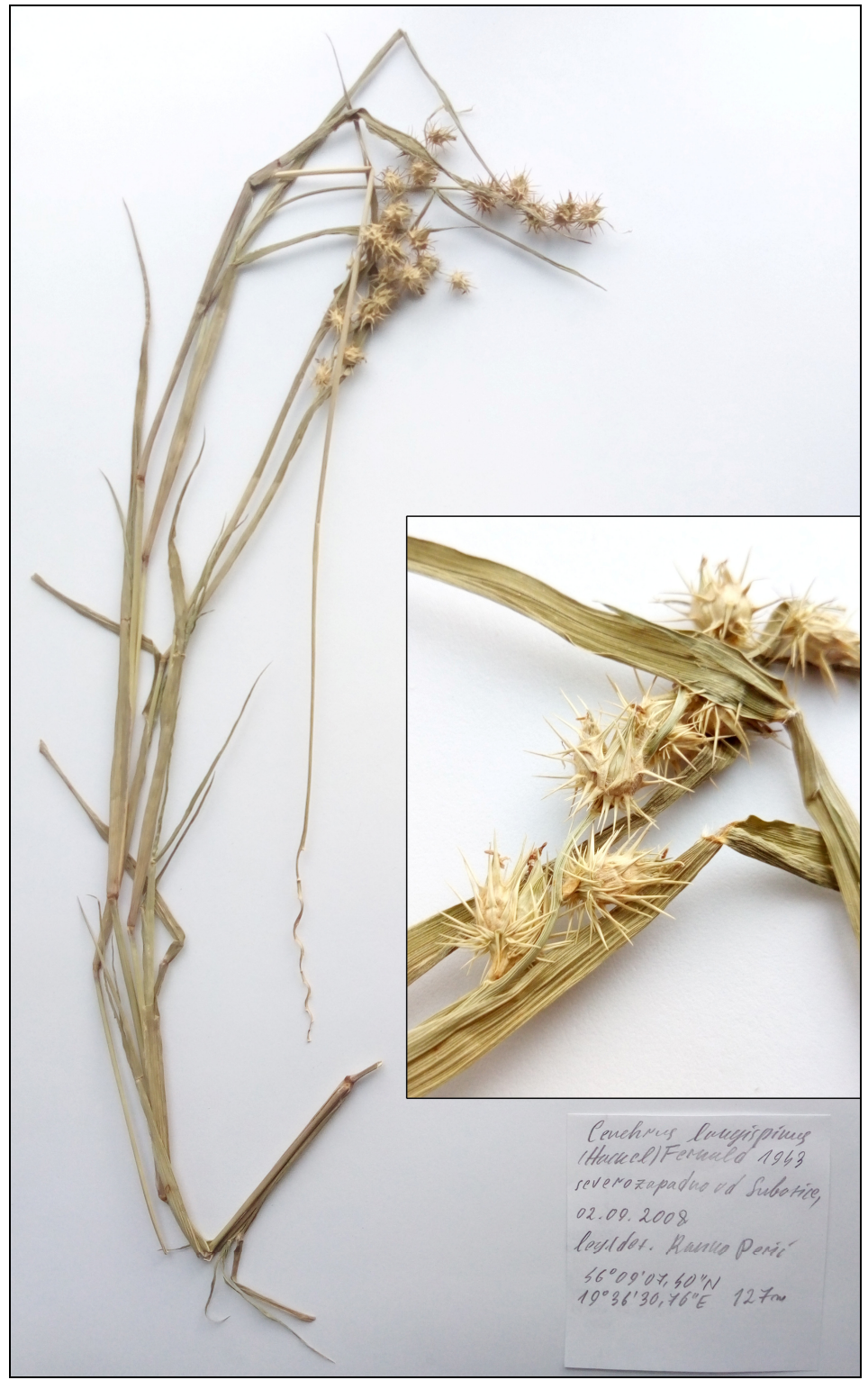

Fig. 14. - Cenchrus longispinus (Hack.) Fernald

(Bačka, Subotica-Horgoš Sands) s.n. PZZP.

Sánchez Gullón 2012) in central Hungary $i$. e. on the same vast sandy area extending in Danube-Tisza interfluve which most southern portion in Serbia is representd by the Subotica-Horgoš Sands. Perić et al. (2009) cited this data (in abstract) as a new grass species for Serbia, but without precise locality. 


\section{First records:}

Bačka, Subotica-Horgoš Sands, Subotica, vicinity of the city, coll. et det. R. Perić 21-Sep-2010 (s.n. PZZP) (Fig. 19);

Bačka, Subotica-Horgoš Sands, Subotica, northwest from the city, 127 m, 19.60854 E, 46.15205 N, MGRS 34T CS91, coll. et det. R. Perić, 02-Sep-2008 (s.n. PZZP) (Figs 14, 19);

Bačka, Subotica-Horgoš Sands, Bački Vinogradi, MGRS 34T DS10, coll. et det. R. Perić, 19-Aug-2008 (s.n. PZZP; s.n. BEO) (Fig. 19).

A new allochtonous species for the flora of Serbia (Vojvodina province), replacing erroneously reported $C$. incertus in this area.

R. Perić

Eragrostis curvula (Schrad.) Nees, Fl. Afr. Austral. Ill.: 397 (1841).

Grass species native to subtropical S Africa and introduced in E and N Africa, Macaronesia, Europe, Asia, Australia, N America and Brasil. For the Balkan Peninsula it is known from S Greece (Damanakis \& Scholz 1990). It belongs to Eragrostis subg. Caesiae Van den Borre \& L. Watson. This is densely caespitose perennial, up to $120(180) \mathrm{cm}$ tall. Culms simple, fibrous, 5-6-noded, slender or robust, usually erect. Leaves glaucous, with narrow blades $30 \times 0.3 \mathrm{~cm}$, arcuate, scabrous, usually involute or filiform, attenuate to a fine, long and flexuous point; sheaths shorter than internodes, scabrous with retrorse hairs at lower part, glabrescent in upper part. Inflorescence a very variable panicle $6-30(35) \times 6-9 \mathrm{~cm}$, spreading to contracted, erect or pendent, with ascending branches, the lowest branches often whorled and pilose in the axils. Spikelets gray-green, linear oblong, 4-10 × 1-1.5 mm, 4-13-flowered, breaking up from the base; glumes lanceolate, 1-veined, with acuminate apex, shorter than lowest floret, lower glume 1.2-1.5 $\mathrm{mm}$, upper glume $1.8-2.5 \mathrm{~mm}$; lemmas ovate to elliptic, 1.8-2.6 $\mathrm{mm}$ long, acute or obtuse, with prominent veins, appressed to the rhachilla; palea as long as lemma, \pm smooth or minutely scaberulous, persistent or tardily deciduous. Stamens 3; anthers ca. $1.2 \mathrm{~mm}$. Caryopsis creamy to dark orange, ellipsoid to obovoid, $0.7 \mathrm{~mm}$ long, dorsally compressed, edible. $2 \mathrm{n}=20,42,63,80$. Species is used for fodder and erosion control, and it is often cultivated as ornamental grass.

In 1984 professor Ž. Blaženčić collected this grass along the Srebrno Jezero reservoir near Veliko Gradište in NE Serbia and provisory identified it as a species of Puccinellia. It grows along the dam that close the cutoff meander on 15-20 cm deep soil. Plant specimens were deposited in BEO for identification. Based on this material, Niketic (2010 in a Book of abstracts) previously mentioned this subtropical grass as a new alien species for the Serbian flora. 


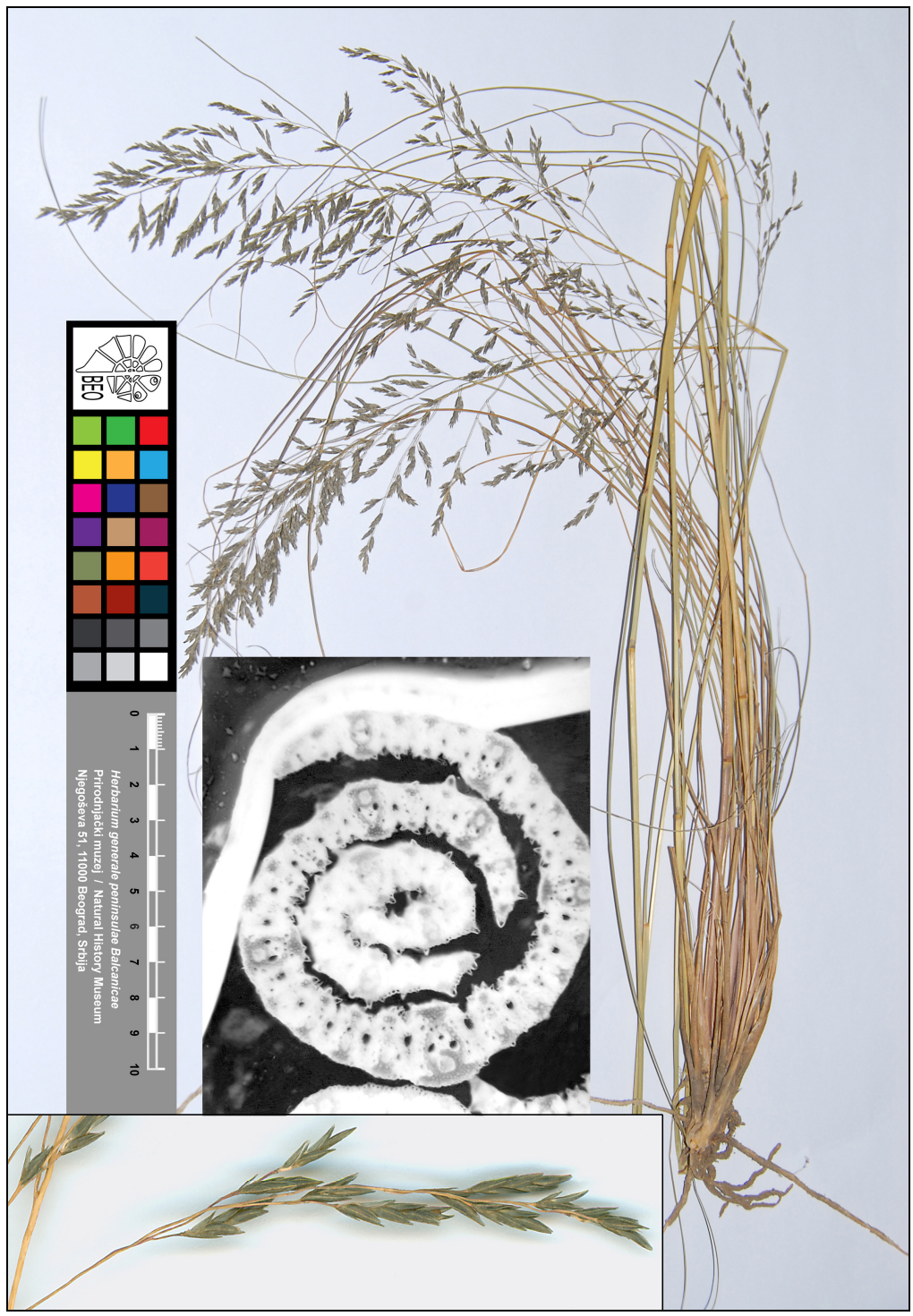

Fig. 15. - Eragrostis curvula (Schrad.) Nees (NE Serbia, Srebrno Lake, BEO 82874 - plant with culm cross section).

\section{First record:}

NE Serbia, Veliko Gradište, Srebrno Lake, on the embankment, MGRS 34T EQ35, coll. et det. Ž. Blaženčić 17-Jul-1984 (sub. Puccinellia convoluta var. festuciformis), rev. N. Jogan (sub Eragrostis sp.), second rev. M. Niketić 14-Feb-2004 (BEO 82874) (Figs 15, 19).

A new allochtonous species for the flora of Serbia. 
Hordeum jubatum L., Sp. Pl. 1: 85 (1753).

This is the only representative of the section Critesion (Rafin.) Nevski in Europe (Humphries 1980). It is native to E Asia and N America and introduced in most of Europe (Valdés et al. 2009). Compared to other

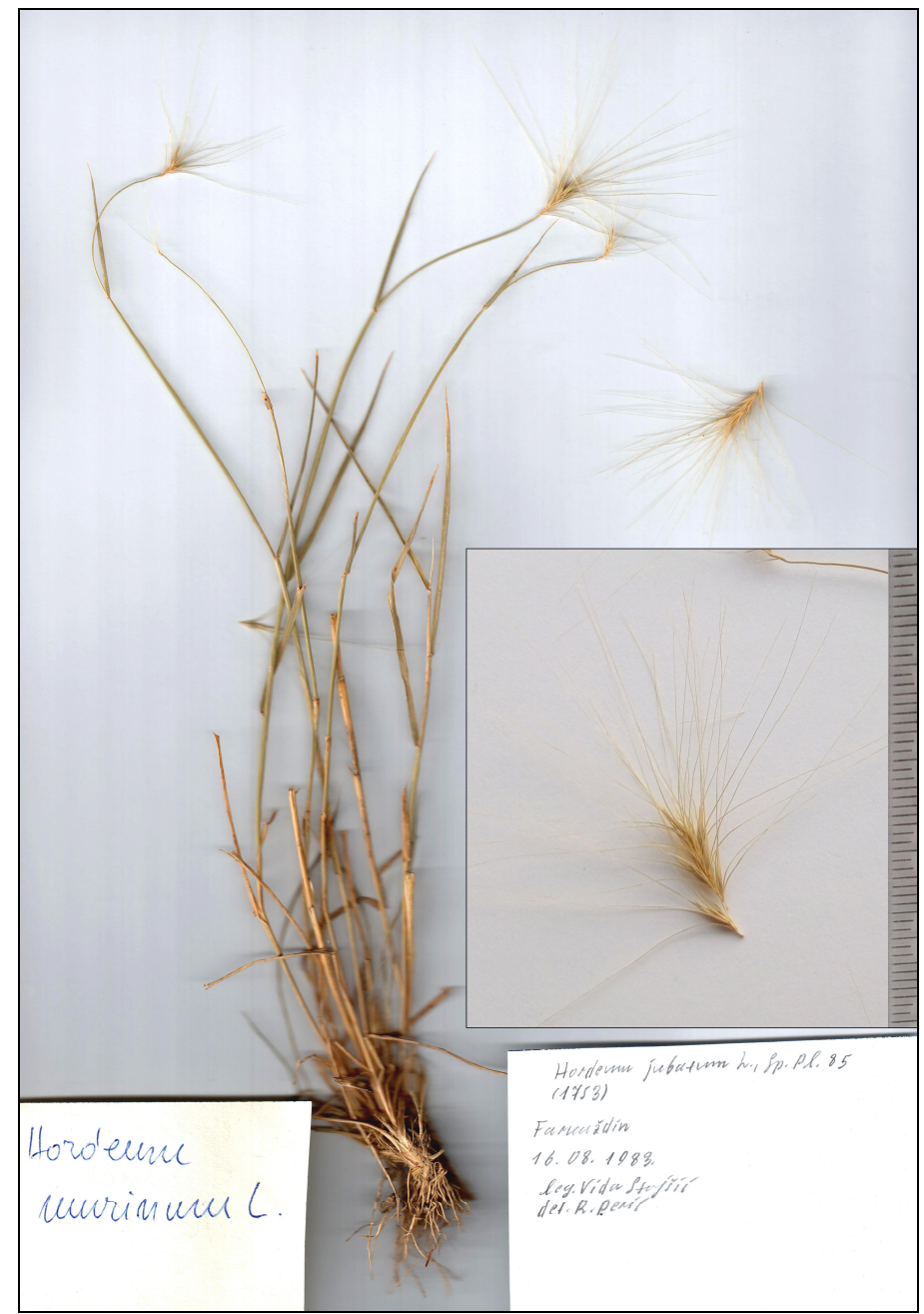

Fig. 16. - Hordeum jubatum L (Banat, Zrenjanin, Farkaždin) s.n. PZZP.

species of this genus in Europe, it can be easily distinguished by the presence of very long glumes $(3-8 \mathrm{~cm})$ which became patent at maturity and lemma of the central spikelet is ending with slender awn $2-10 \mathrm{~cm}$ long (Humphries 1980). The only data regarding its presence in Serbia originates from single gathering in the vicinity of Farkaždin more than three decades ago. Despite intense floristic field work conducted during the last decade in 
this area $H$. jubatum had not been collected again, suggesting its rather casual status in Serbia.

First record:

Banat, Zrenjanin, Farkaždin, MGRS 34T DR50, coll. et det. V. Stojšić 16-Aug-1983 (sub H. murinum), rev. R. Perić) (s.n. PZZP) (Figs 16, 19). A new allochtonous species for the flora of Serbia.

R. Perić

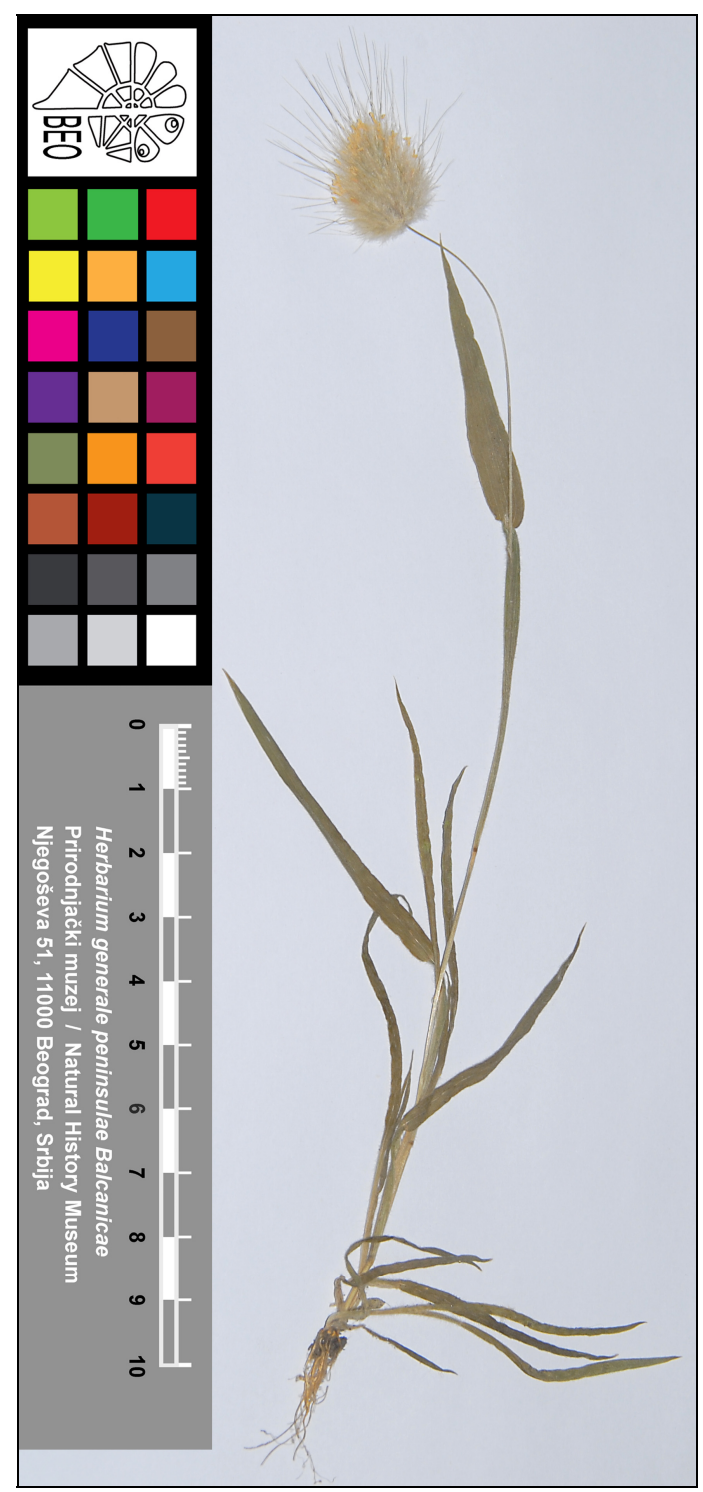

Fig. 17. - Lagurus ovatus L. (Šumadija, Beograd, Vračar) BEO 82877.
Lagurus ovatus L., Sp. Pl. 1: 81 (1753).

Godra (1872) was the first botanist who mentioned this Mediterranean plant in Srem region (along Sava river banks) in Vojvodina province.

Recently, Niketić (2000 in a Book of abstracts) also cited this grass as a new alien species for Serbia from urban area in the city of Belgrade in crevices at the bottom of the house wall.

The same plant spontaneously appeared in May 2005. in Botanical garden "Jevremovac" in Belgrade in a very similar place (D. Lakušić, observ.). Plant was not seen during the following years.

\section{New record:}

Šumadija, Beograd, Vračar, MGRS 34T

DQ56, coll. et det. M.

Niketić 18-May-1996

(BEO 82877) (Fig. 17).

Confirmed ephemeralal alochthonous species for the flora of Serbia.

M. Niketić, D. Lakušić 
Panicum barbipulvinatum Nash ex Rydb., Mem. New York Bot. Gard. 1: 21 (1900).

$$
=\text { P. riparium } \mathrm{H} \text {. Scholz, Feddes Repert. 113: } 275 \text { (2002) }
$$

A neophytic ruderal grass coming from the New World $P$. capillare complex (Panicum L. sect. Panicum). Compared with P. capillare L. it has more lanceolate spikelets (length/width $2.7-3.4$ vs. 2.2-2.7) and ripe fertile florets (length/width $1.5-1.7 \mathrm{~mm}$ vs. $1.8-2.2 \mathrm{~mm}$ ) on distinctly shorter panicle-branches (1.0-1.8(3) vs. $5 \mathrm{~mm}$ or more), appressed to the branch. The diasporae (i.e. ripe fertile floret, falling from ripe spikelets) of $P$. barbipulvinatum are narrow, rather oblong-ovate, while the those of $P$. capillare are broadly ovate. Besides, ripe spikelets of $P$. barbipulvinatum are much more persistent.

Plant was relatively recently described as a new species that probably evolved from American taxa in C Europe (Scholz 2002, P. riparium). However, Amarell et al. (2014) proved that the same plants has already been described from $\mathrm{N}$ America under the name $P$. barbipulvinatum. In their opinion species of $P$. capillare complex were introduced in Europe in $18^{\text {th }}$ century. Unlike those authors, Clayton et al. (2018) synonymized both names with $P$. capillare. According to Valdés et al. (2009) P. barbipulvinatum is widespread naturalized alien in $\mathrm{C}$ and $\mathrm{E}$ Europe. For the Balkan countries and neighboring Hungary species is reported for Hungary (Király et al. 2009), Slovenia (Jogan \& Martinčić 2015), Croatia (Király \& Alegro 2015), Romania and Bosnia and Herzegovina (Nobis et al. 2016), under the name $P$. riparium respectively.

During revision of grasses in the Herbarium of the Institute of nature conservation of Vojvodina province, Novi Sad (PZZP), some material belonging to the discussed species was found in the folder previously determined as $P$. capillare (coll. B. Šajinović) from several localities in Vojvodina province.

\section{First records:}

Banat, Pančevo, Ivanovo, "Forland III, SO Pančevo", the area of full cuts on the "Ivanovo" Nature Reserve enclosure, MGRS 34T DQ75, coll. B. Šajinović 13-Sep-1974, det. R. Perić (sub P. capillare), rev. N. Jogan 2017 (sub P. riparium) (s.n. PZZP) (Figs 18, 19).

Bačka, Crvenka, railroad station, MGRS 34T CR75, coll. B. Šajinović 13-Sep-1974, det. R. Perić (sub P. capillare), rev. N. Jogan 2017 (sub P. riparium) (s.n. PZZP) (Fig. 19).

Bačka, Titel, railroad station, MGRS 34T DR40, coll. B. Šajinović 13Sep-1974, det. R. Perić (sub P. capillare), rev. N. Jogan 2017 (sub P. riparium) (s.n. PZZP) (Fig. 19). 


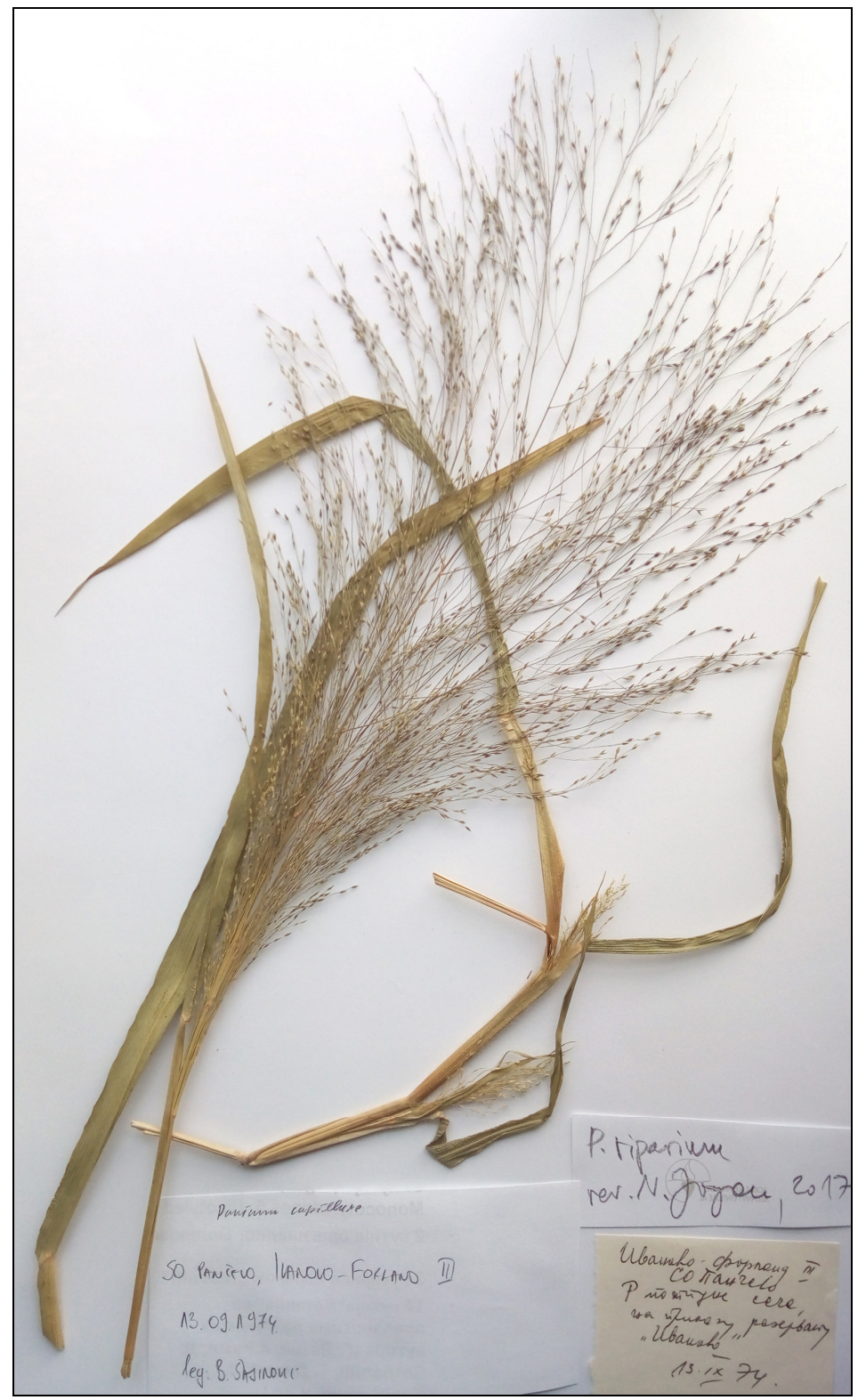

Fig. 18. - Panicum barbipulvinatum Nash ex Rydb. (Banat, Ivanovo) s.n. PZZP.

Srem, Inđija, railroad station, MGRS 34T DQ28, coll. B. Šajinović 13Sep-1974, det. R. Perić (sub P. capillare), rev. N. Jogan 2017 (sub P. riparium) (s.n. PZZP) (Fig. 19).

A new allochthonous species for the flora of Serbia. 
Panicum dichotomiflorum Michx., F1. Bor.-Amer. 1: 48 (1803).

North, Central and South American plant from Panicum sect. Dichotomiflora (Hitchc. \& Chase) Honda. Representatives of this section have a glabrous leafsheets and leafblades (except $P$. bartowense Scribn. \& Merr.) and lower glumes up to $1 / 4$ as long as spikelets, truncate or triangulartipped. In the type section (represented in our flora by e.g. P. capillare L.) plants have papillose to patent hispid-pilose sheets and leaves while lower glumes usually $1 / 2$ as long as spikelets, acute or acuminate.

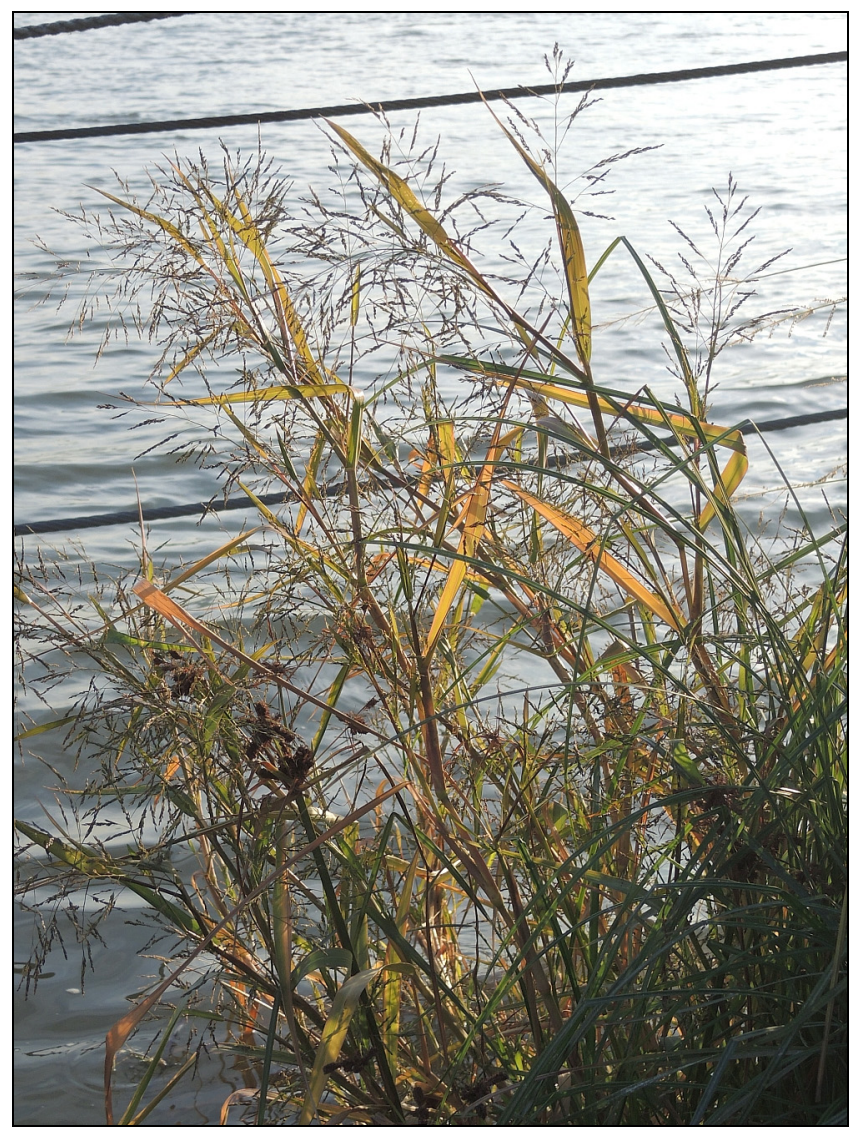

Fig. 18. - Panicum dichotomiflorum Michx. (Bačka, Novi Sad, Ribarsko Ostrvo) (photo N. Jogan).

Species grows in different natural and disturbed habitats in the homeland. In Europe, it was first discovered in 1881 in Belgium (Petrova et al. 2013) and has been spreaded so far to most countries except on the north (Valdés et al. 2009). It is usually seen on wet ruderal places and in arable land, often as a weed of various cultures. For the region of SE Europe and neighboring Hungary it has been known for a long time only from Romania (Hegi 
1935). In the last four decades it was also found in Croatia (Hulina 1985), Slovenia (Jogan 1990), Hungary (Csiky et al. 2004), Greece (AnagnouVeroniki et al. 2008), Bulgaria (Petrova \& Vladimirov 2012), Albania (Barina et al. 2013) and Bosnia and Hercegovina (Maslo \& Šarić 2016).

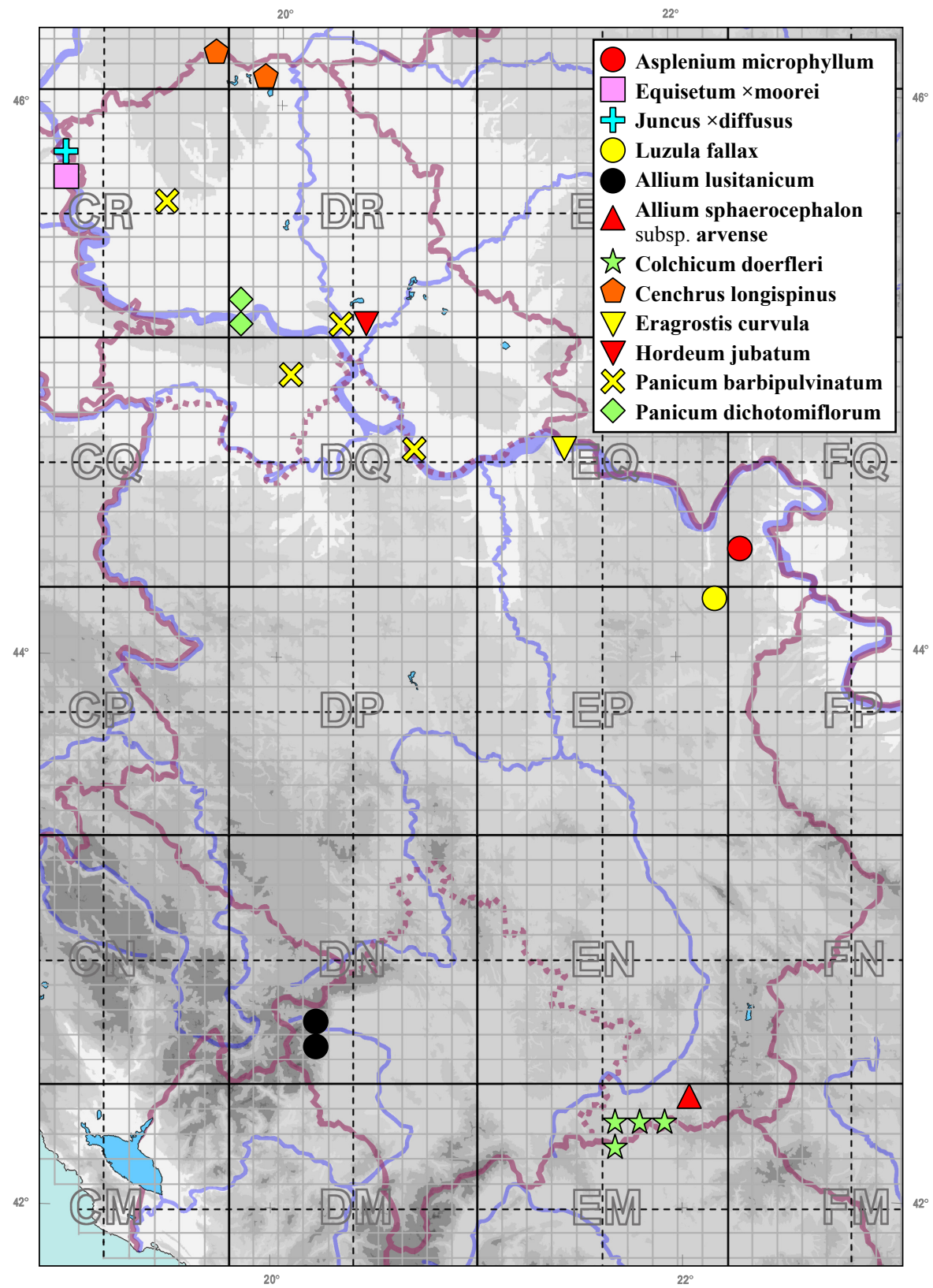

Fig. 19. - Distribution of some new taxa for the vascular flora of Serbia. 
During revision of the Herbarium of the University of Novi Sad (BUNS) a material collected in 2004 by P. Boža in Vojvodina province (Novi Sad) was easily recognized as $P$. dichotomiflorum. In addition to that, dense populations of that species was found on the banks of Danube river in Novi Sad by the author.

\section{First records:}

Bačka, Novi Sad, Novo Naselje, MGRS 34T DR01, coll. P. Boža 06Sep-2004, det. N. Jogan 2017 (s.n. BUNS) (Fig. 19).

Bačka, Novi Sad, Ribarsko Ostrvo, MGRS 34T DR00, coll. et det. N. Jogan, 05-Nov-2017 (s.n. LJU) (Figs 18-19).

A new allochthonous species for the flora of Serbia.

N. Jogan

\section{New and confirmed taxa for the flora of administrative units LILIOPSIDA}

LILIACEAE (ASPARAGACEAE)

Asparagus pseudoscaber Grecescu, Consp. Fl. Roman.: 556 (1898).

Pančić (1874) was the first botanist who found this rare plant in two localities in Belgrade (Makiš and Ada Ciganlija) and this records were also taken by the authors of this family in the Flora of SR Serbia (Vukićević \& Diklić 1975, sub A. scaber Brign.). Jovanović (1999) considered that this plant extinct both from Zemun (Bežanija hill) and the surrounding of Aleksinac. Having in mind that there were only two localities in Serbia with a small subpopulations in Makiš and Novi Beograd, this plant was assessed as Critically Endangered species in the flora of Serbia.

In the locality Turske Livade in the Special Nature Reserve "Zasavica" only one blooming specimen was found. This rare plant is growing in the immediate vicinity of the parking place, within the small and restricted remnant of Quercus robur L. forest, together with several species, such as: Acer tataricum L., Ulmus glabra Huds., Crataegus monogyna Jacq., Clematis integrifolia L., Viola elatior Fr., etc.

First record:

Vojvodina, Srem [in geographical terms, northern part od the Mačva Plain in NW Serbia], Zasavica, Turske Livade, $80 \mathrm{~m}$, the edge of the oak forest Brachypodio silvaticae palustris-Quercetum., $19.5273818^{\circ} \mathrm{E}$, $44.9607979^{\circ} \mathrm{N}$, MGRS 34T CQ87, coll. et det. M. Niketić, G. Tomović, M. Stanković 17-May-2017 (BEO 82872) (Fig. 20). 


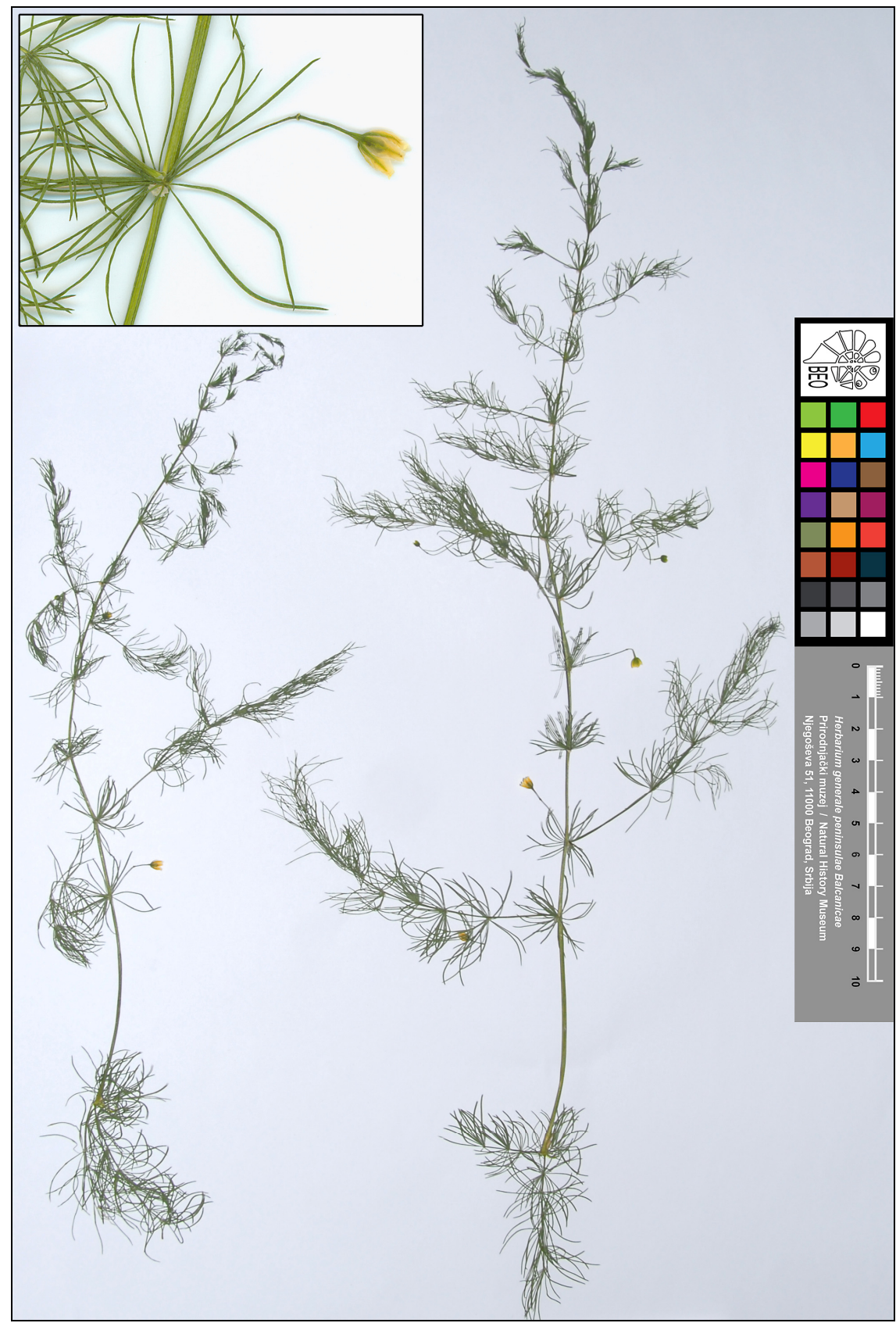

Fig. 20. - Asparagus pseudoscaber Grecescu (Vojvodina, Mačva, Zasavica) BEO 82872.

A new species for the flora of Vojvodina province. 
Tulipa sylvestris subsp. australis (Link) Pamp., Boll. Soc. Bot. Ital. 1914: 114 (1914).

First data on the native presence of this taxon in Serbia originates from Hayek (1924), who found it in Mt Paštrik (sub T. grisebachiana Pant.). Quite recently Duraki et al. (2017) confirmed the presence of this subspecies in the flora of Kosovo and Metohija province in Mts. ŠarPlanina (Mt Kobilica).

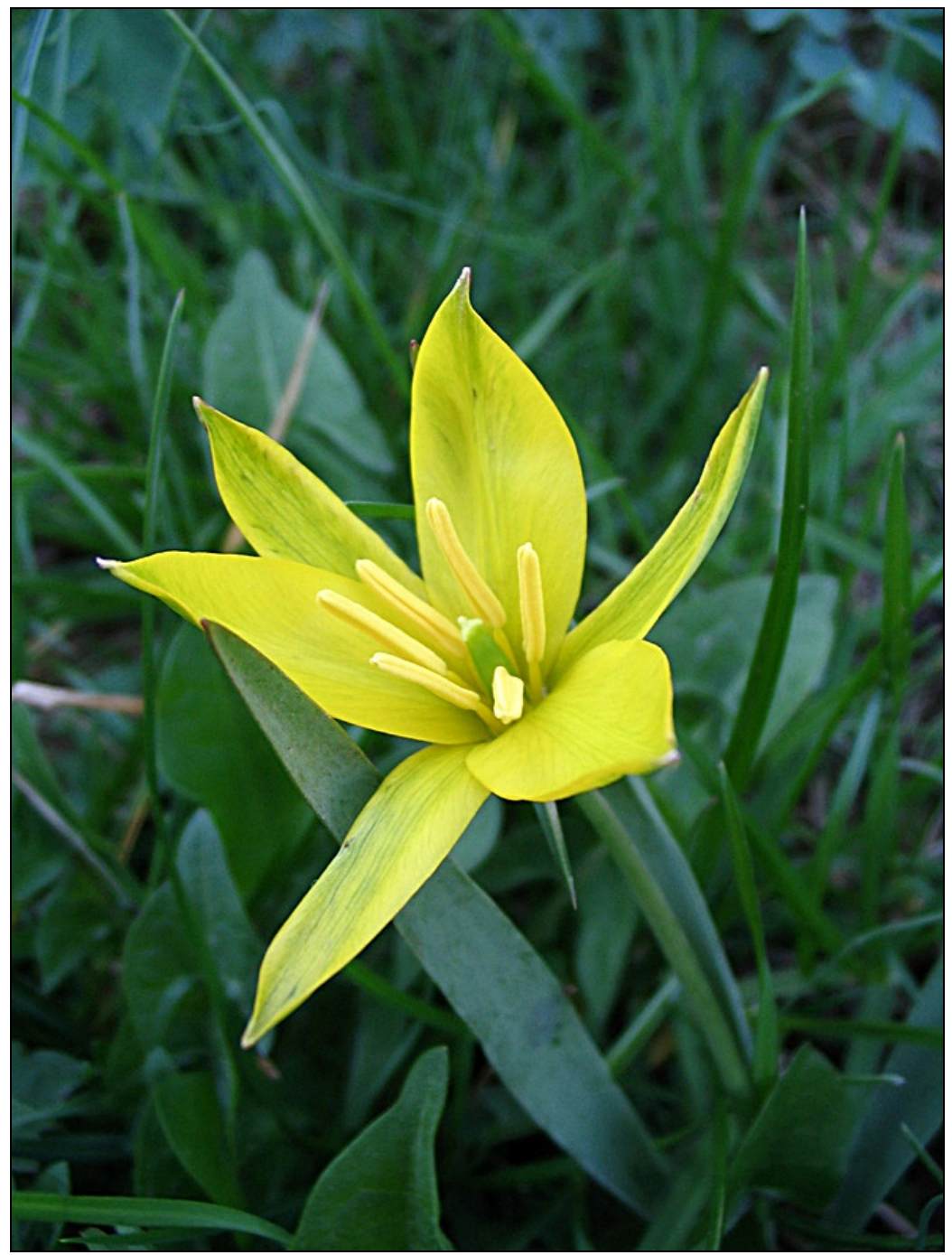

Fig. 21. - Tulipa sylvestris subsp. australis (Link) Pamp. (SE Serbia, Mt Kozjak) (photo B. Zlatković).

Previous data concerning Serbia proper from the Flora of SR Serbia (Diklić 1975) relate only to cultivated ornament plants, which in the past 
had appeared ephemerally in the natural environment in the vicinity of Niš (according to Pančić and Petrović, sub T. sylvestris L.). Otherwise, in Euro+Med (2006-) and the "World Checklist of Selected Plant Families" (Govaerts et al. 2018) the name T. grisebachiana is erroneously attributed to the type subspecies that grows in Italy and Libya, instead to $T$. $s$. subsp. australis which certainly grows on the Balkan Peninsula.

\section{First records:}

SE Serbia, Mt Kozjak, Delinovički rid, thermophilous shrubby formation (Ostryo-Carpinion aegeicum), migmatite, $560 \mathrm{~m}$, MGRS 34T EM78, coll. et det. B. Zlatković 16-May-2004 (614 BEOU).

SE Serbia, St. Prohor Pčinjski Monastery, surroundings, thermophilous shrubby formation (Ostryo-Carpinion aegeicum), fine-grained biotite and biotite-muscovite gneiss, $430 \mathrm{~m}$, MGRS 34T EM78, coll. et det. B. Zlatković 16-May-2005 (BEOU, coll. No. 1427).

A new native subspecies for the flora of Serbia proper (Fig. 21).

\section{B. Zlatković}

\section{POACEAE (GRAMINEAE)}

Aira elegans Willd. ex Roem. \& Schult., Syst. Veg. 2: 682 (1817).

This Submediterranean grass was firstly published by Pančić (1856 sub A. capillaris Host) for the vicinity of Kragujevac (Dobrača village). Adamović (1904 sub A. capillaris Host) cited it for Serbia proper but without precise locality. Cincović \& Kojić (1976 sub A. capillaris Host) considered this plant as widely distributed in Serbia, but they did not provide any locality.

Its typical habitats in Serbia are stony grasslands, thermophilous open hilly meadows and forest edges, predominantly in limestone areas of E, SE and S Serbia (Jovanović 1955, Cincović \& Kojić 1976, Ranđelović 1979, Ranđelović et al. 1979, Ranđelović 1979-1980, Ružić \& Ranđelović 1986). Recently discovered population of this species in the vicinity of Aradac village represents the only known data confirming its presence in Vojvodina province. Its habitat is characterized by alkali salt-steppic community Artemisio-Festucetum pseudovinae Soó in Máthé 1933.

\section{First record:}

Banat, Zrenjanin, Aradac, Kamarište, 73 m, 20.30961 E, 45.34415 N, MGRS 34T DR42, coll. et det. R. Perić 16-Jun-2017 (sub A. elegantissima), rev. N. Jogan 2017 (s.n. PZZP) (Fig. 22).

A new species for the flora of Vojvodina province. 
144 Niketić, M. et al.: AnNotated Checklist of Vascular Flora of Serbia I

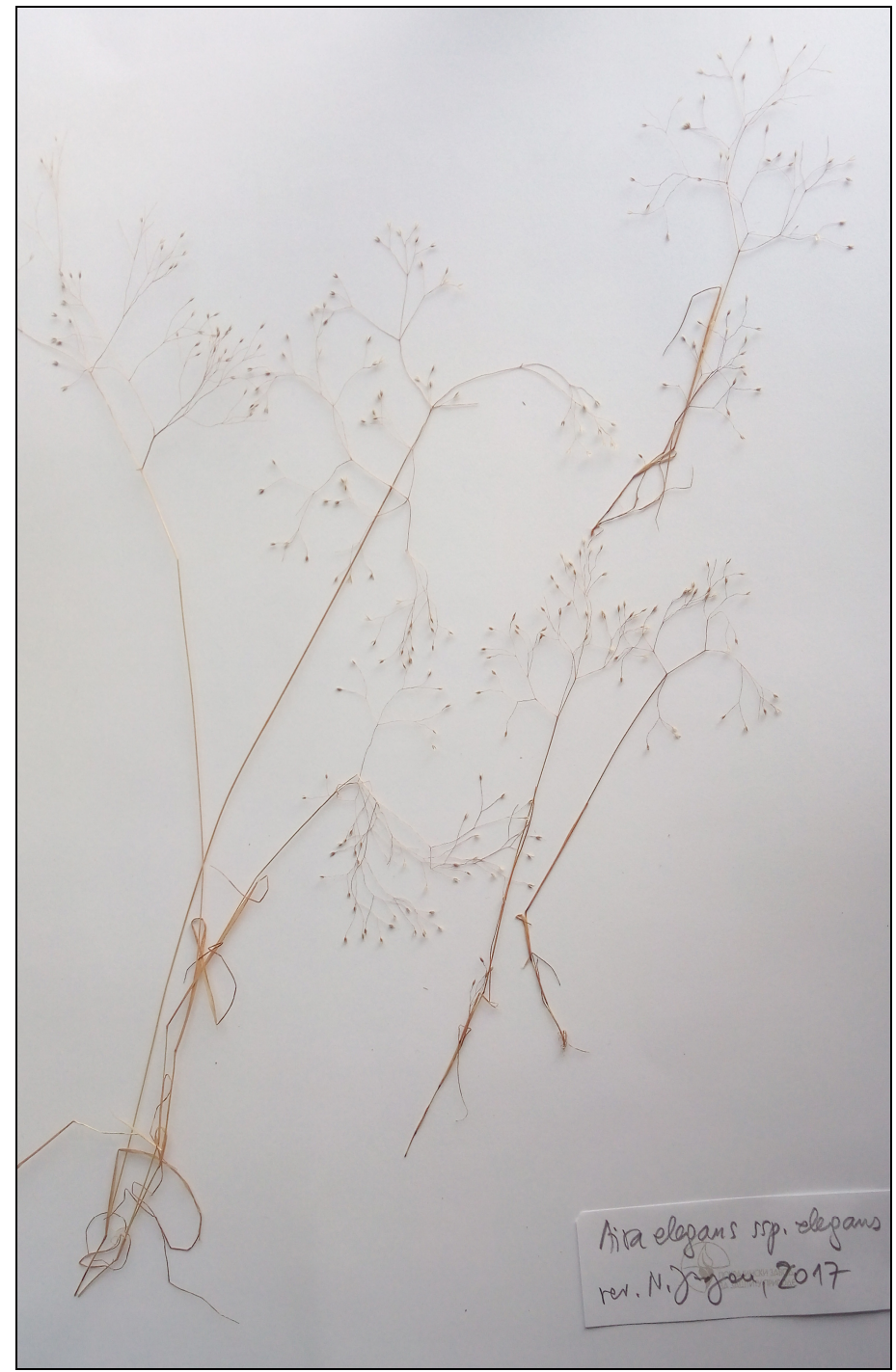

Fig. 22. - Aira elegans Willd. ex Roem. \& Schult. (Banat, Zrenjanin, Aradac) s.n. PZZP.

Catapodium rigidum (L.) C. E. Hubb., in Dony, Fl. Bedfordshire: 437 (1953) subsp. rigidum

Rumy (1846 sub “Megastachya rigida (L.) Roem. \& Schult.”) erroneously cited this taxon for the town of Sremski Karlovci in Vojvodina province.

For the flora of Serbia proper it was firstly published by Fritsch [1909 sub Scleropoa rigida (L.) Griseb.] for Vranje and this record was taken by 
the authors in the Flora of SR Serbia [Cincović \& Kojić 1976 sub Scleropoa rigida (L.) Griseb.]. Nikolić et al. ([1986 sub Scleropoa rigida (L.) Griseb.] listed one new locality in the foothill of Mt Paštrik (Gorožup village) in Kosovo and Metohija province.

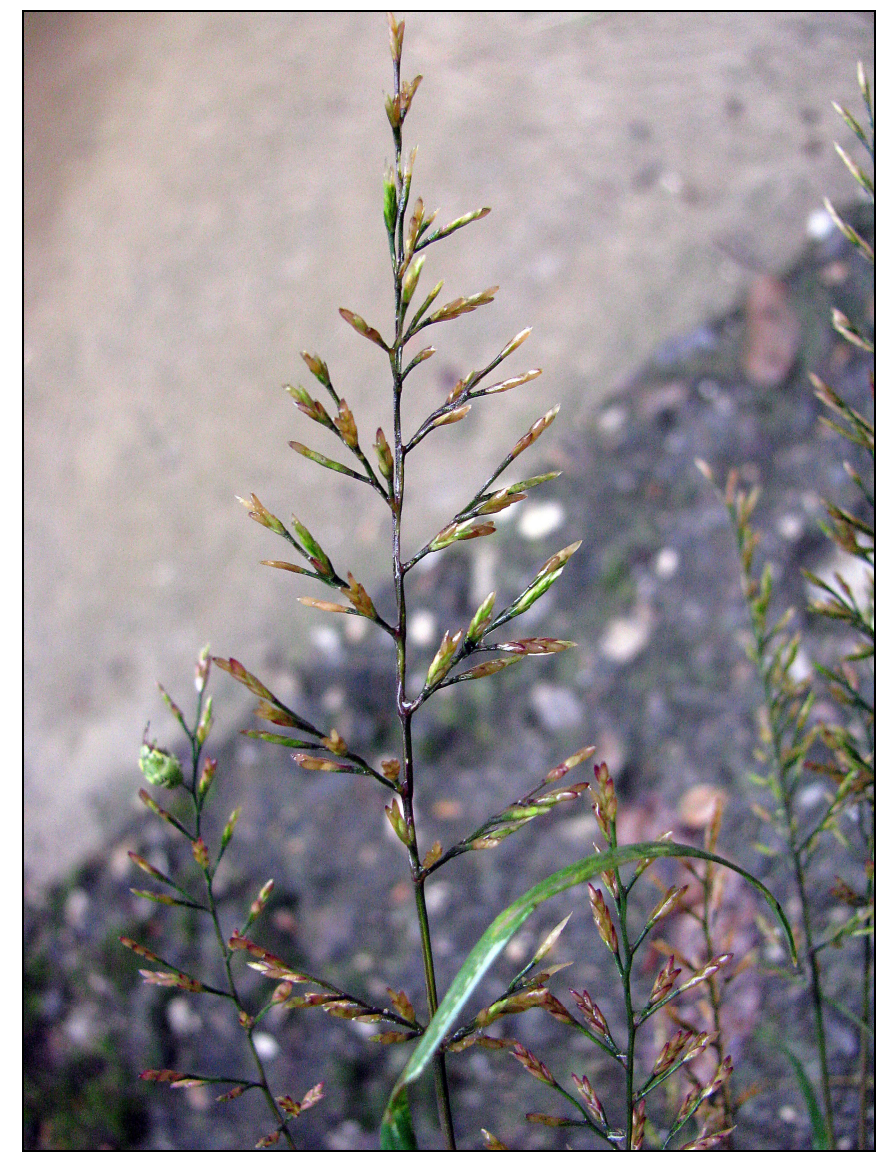

Fig. 23. - Catapodium rigidum (L.) C. E. Hubb. (Metohija, Prizren, Prizrenska Bistrica Gorge) (photo B. Zlatković).

\section{New records:}

Metohija, Prizren, Prizrenska Bistrica Gorge, ruderal places and thermophilous pastures on shallow substrate, limestone, $380 \mathrm{~m}$, MGRS 34T DM87, coll. et det. B. Zlatković 30-Jun-1996 (HMN 13875) (Fig. 23).

W Serbia, Ovčarsko-Kablarska Gorge, MGRS 34T DP36, coll. P. Boža 21-May-1966, det. N. Jogan (s.n. BUNS).

Confirmed species for the flora of Kosovo and Metohija province and Serbia proper. 
Cleistogenes serotina (L.) Keng, Sinensia 5: 149 (1934) subsp. serotina

For Vojvodina province it was firstly reported by Rumy (1846 sub Festuca serotina L.) for the town of Sremski Karlovci, as well as by Schulzer et al. [1866 sub Molinia serotina (L.) Mert. \& W. D. J. Koch] for Zemun city in the region of Srem.

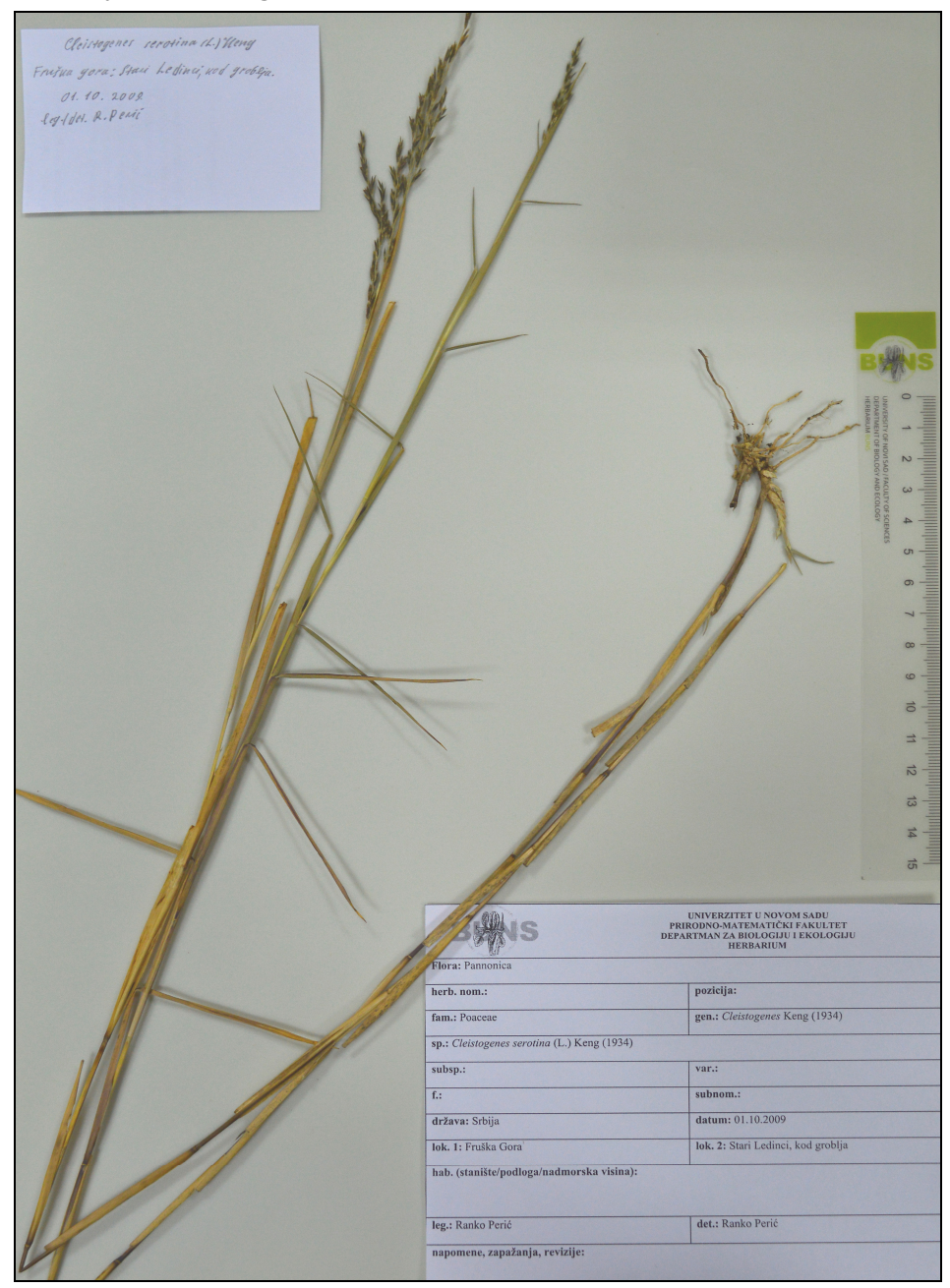

Fig. 24. - Cleistogenes serotina (L.) Keng (Srem, Mt Fruška Gora, Stari Ledinci) s.n. BUNS.

Pančić [1856 sub Molinia serotina (L.) Mert. \& W. D. J. Koch] found this grass near Jagodina setllement (Đurđevo hill) and near Belgrade (Topčider hill) in Serbia proper.

Cincović \& Kojić [1976 sub Diplachne serotina (L.) Link] listed three sites in Šumadija region (Belgrade - Višnjička Kosa and Košutnjak hill and 
Kragujevac - Badnjevac village), while Nikolić et al. [1986 sub Diplachne serotina (L.) Link] numbered several new localities for Serbia proper: Mt Ozren, Niš (Mt Seličevica, Kamenica, Banjsko hill), Pirot (Temska), Babušnica, Mt Vidojevica (Sokolica peak).

\section{New records:}

Srem, Mt Fruška Gora, Stari Ledinci, (surrounding of the village cemetery), MGRS 34T DR00, coll. et det. R. Perić 01-Sep-2009 (s.n. PZZP) (Fig. 24).

Srem, Petrovaradin, MGRS 34T DR11, obs. N. Jogan 24-Sep-2017 (field observation).

Confirmed species for the flora of Vojvodina province. However, it is assumed that this species grows more frequently in loess steppic and hilly areas of Vojvodina province.

R. Perić, N. Jogan

Festuca lachenalii (C. C. Gmel.) Spenn., Fl. Friburg. 3: 1050 (1829).

This species was firstly reported by Adamović [1904 sub Nardurus poa (Lam. \& DC.) Boiss.] for vicinity of Vranje (Preobraženje village) and this record was accepted by Nikolić et al. [1986 sub Nardurus lachenalii (C. C. Gmel.) Godr.].

In the Flora of SR Serbia it was considered as sporadically distributed [Cincović \& Kojić 1976 sub Nardurus lachenalii (C. C. Gmel.) Godr.].

Zlatković [2011 sub Micropyrum tenellum (L.) Link] reported this plant for Pčinja river valley.

\section{New records:}

SE Serbia, Pčinja river valley, Jablanica village, terophytic siliceous grasslands (Trifolion cherlerii), fine-grained biotite and biotite-muscovite gneiss, $560 \mathrm{~m}$, MGRS 34T EM78, coll. et det. B. Zlatković 25Apr-2000 (BEOU, coll. No. 2339).

SE Serbia, Kostin Čukar, Vogance - Jablanica, perennial open siliceous grasslands (Sedo-Dianthetum pinifoliae), fine-grained biotite and biotite-muscovite gneiss, $800 \mathrm{~m}$, MGRS 34T EM78, EM79, coll. et det. B. Zlatković 15-May-2004 (BEOU, coll. No. 1780).

SE Serbia, St. Prohor Pčinjski Monastery, Golet, terophytic siliceous grasslands (Trifolio-Lotetum angustifoliae), granite, 415 m, MGRS 34T EM78, coll. et det. B. Zlatković Jul-1999 (BEOU, coll. No. 2752).

SE Serbia, St. Prohor Pčinjski Monastery, Krst, dry siliceous rock debris (Scillo autumnalae-Sedetum stefco), migmatite, 450 m, MGRS 
34T EM78, coll. B. Zlatković, V. Ranđelović, G. Tomović 08-Jul-1997, det. B. Zlatković (BEOU, coll. No. 2065).

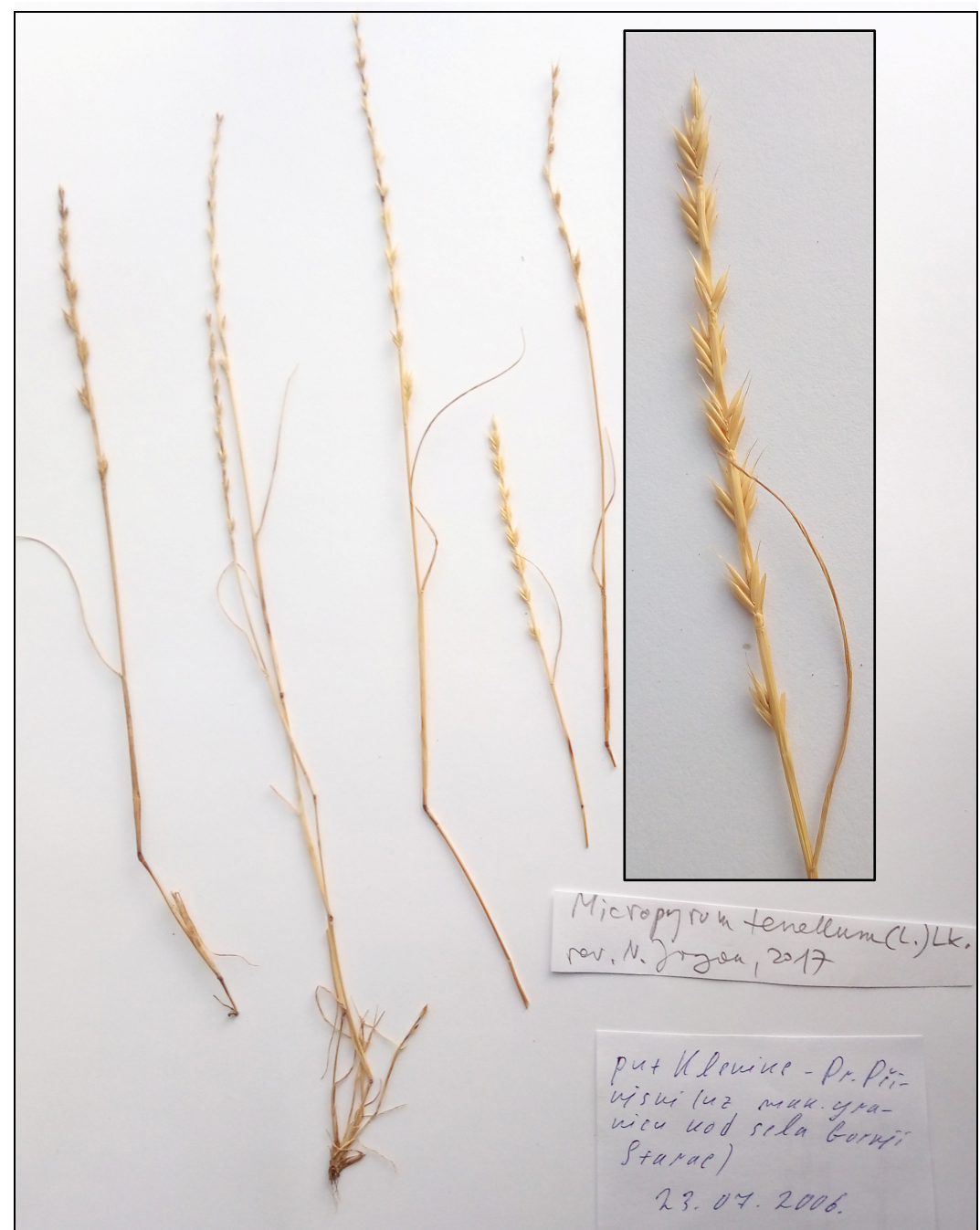

Fig. 25. - Festuca lachenalii (C. C. Gmel.) Spenn. (SE Serbia, Mt Starac) s.n. PZZP.

SE Serbia, St. Prohor Pčinjski Monastery, Krst, perennial open siliceous grasslands (Sedo-Dianthetum pinifoliae), fine-grained biotite and biotite-muscovite gneiss, $450 \mathrm{~m}$, MGRS 34T EM78, coll. B. Zlatković, V. Ranđelović Jul-1998, det. B. Zlatković (BEOU, coll. No. 1964).

SE Serbia, St. Prohor Pčinjski Monastery, surrounding, terophytic siliceous grasslands (Trifolion cherlerii), fine-grained biotite and 
biotite-muscovite gneiss, $430 \mathrm{~m}$, MGRS 34T EM78, coll. B. Zlatković, V. Ranđelović 05-Aug-2004, det. B. Zlatković (BEOU, coll. No. 653).

SE Serbia, Mt Starac, Budovija, dwarf annual siliceous grasslands and sands (Ornithopodi-Tuberarietum guttatae), fine-grained biotite and biotite-muscovite gneiss, 680 m, MGRS 34T EM78, coll. B. Zlatković, V. Ranđelović, G. Tomović 08-Jul-1997, det. B. Zlatković (BEOU, coll. No. 2073).

SE Serbia, Mt Starac, Gornji Starac village, dwarf annual siliceous grasslands and sands (Ornithopodi-Tuberarietum guttatae), migmatite, 800 m, MGRS 34T EM78, coll. et det. B. Zlatković 20-May-2004 (BEOU, coll. No. 1903).

SE Serbia, Mt Starac, Gornji Starac village, along the state border, MGRS 34T EM78, coll. R. Perić 23-Jul-2006, det. N. Jogan (sub Micropyrum tenellum) (s.n. PZZP) (Fig. 25).

Confirmed species for the flora of Serbia proper.

B. Zlatković, R. Perić, N. Jogan

Festuca rubra L., Sp. Pl. 1: 74 (1753).

Rumy (1846) (sub F. dumetorum L. and F. duriuscula L.) published this plant for Sremski Karlovci and after him Zorkóczy (1896) also found it near Sremski Karlovci (locality Grgeteg). These were the oldest two records for Vojvodina province. Its last known field records from Vojvodina are dating back to the beginning of the 1980s (published later by Panjković-Matanović 1989 and Budak 1998).

For Kosovo and Metohija it was firstly reported by Grisebach [1846 sub F. ovina var. duriuscula (L.) W. D. J. Koch] for Mts. Šar-Planina (Mt Kobilica and Mt Ljuboten).

Pančić (1856 sub F. $r$. var. rubra) reported that he found this specis near Kragujevac (Banja village) and later, the same author [Pančić 1888 sub F. $r$. var. fallax (Thuill.) Hack.] cited it for Serbia proper, but without precise locality.

In the Flora of SR Serbia [Cincović \& Kojić 1976 sub F. r. subsp. rubra and F. r. subsp. fallax (Thuill.) Nyman] it was reported for several localities in Serbia proper (Mt Jablanik, Mt Ozren, Mt Suva Planina) and Kosovo and Metohija province (Mts. Prokletije - gorge near Peć, Mt Dečanske Planine and Mt Kurvala).

Nikolić et al. [1986 sub F. r. subsp. rubra and F. r. subsp. fallax (Thuill.) Nyman] numbered several new records: vicinity of Bajina Bašta, Mt Mokra Gora, Mt Zlatibor, Mt Vidojevica (Perine Livade) and Mt 
150 Niketić, M. ET AL.: ANNOTATEd CheCKList of VASCUlar Flora OF SERBia I

Kopaonik in Serbia proper as well as Mts. Prokletije (Mt Koprivnik) in Kosovo and Metohija province.

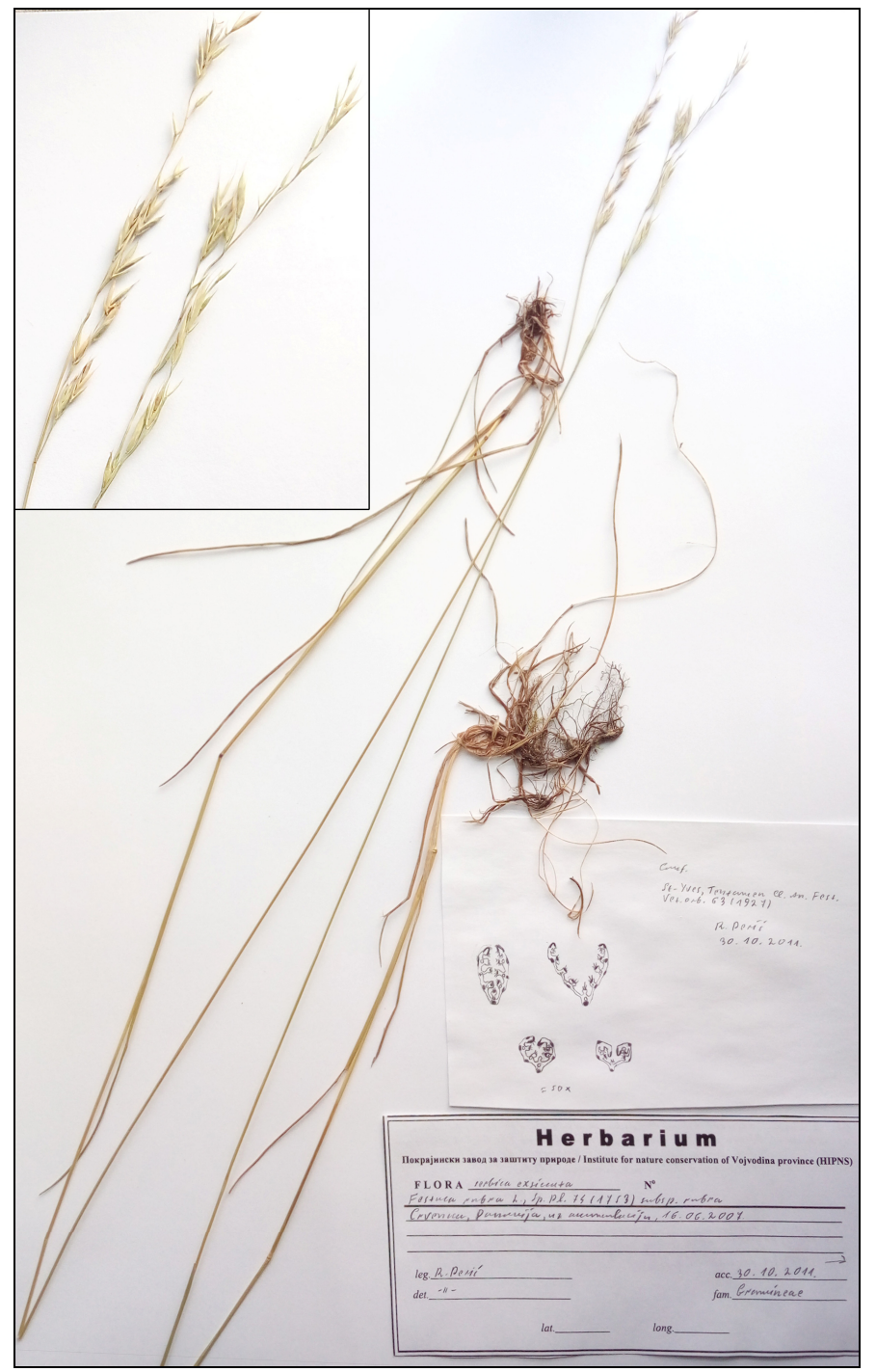

Fig. 26. - Festuca rubra L. (Bačka, Bačka Topola, Bajša) s.n. PZZP.

New record:

Bačka, Bačka Topola, Bajša ["Crvenka"], Panonija, near accumulation lake, MGRS 34T CR86, coll. et det. R. Perić 16-Jun-2007 (s.n. PZZP) (Fig. 26).

Confirmed species for the flora of Vojvodina province. 
Secale sylvestre Host, Icon. Descr. Gram. Austriac. 4: 7 (1809).

Pančić (1863 sub S. fragile M. Bieb.) mentioned this grass for Serbia proper, but without precise locality. Later he found this plant on sands near Ram and Radujevac villages in Ramska Sands (Pančić 1874 sub S. fragile M. Bieb.) (both localities were later cited by Cincović \& Kojić 1976).

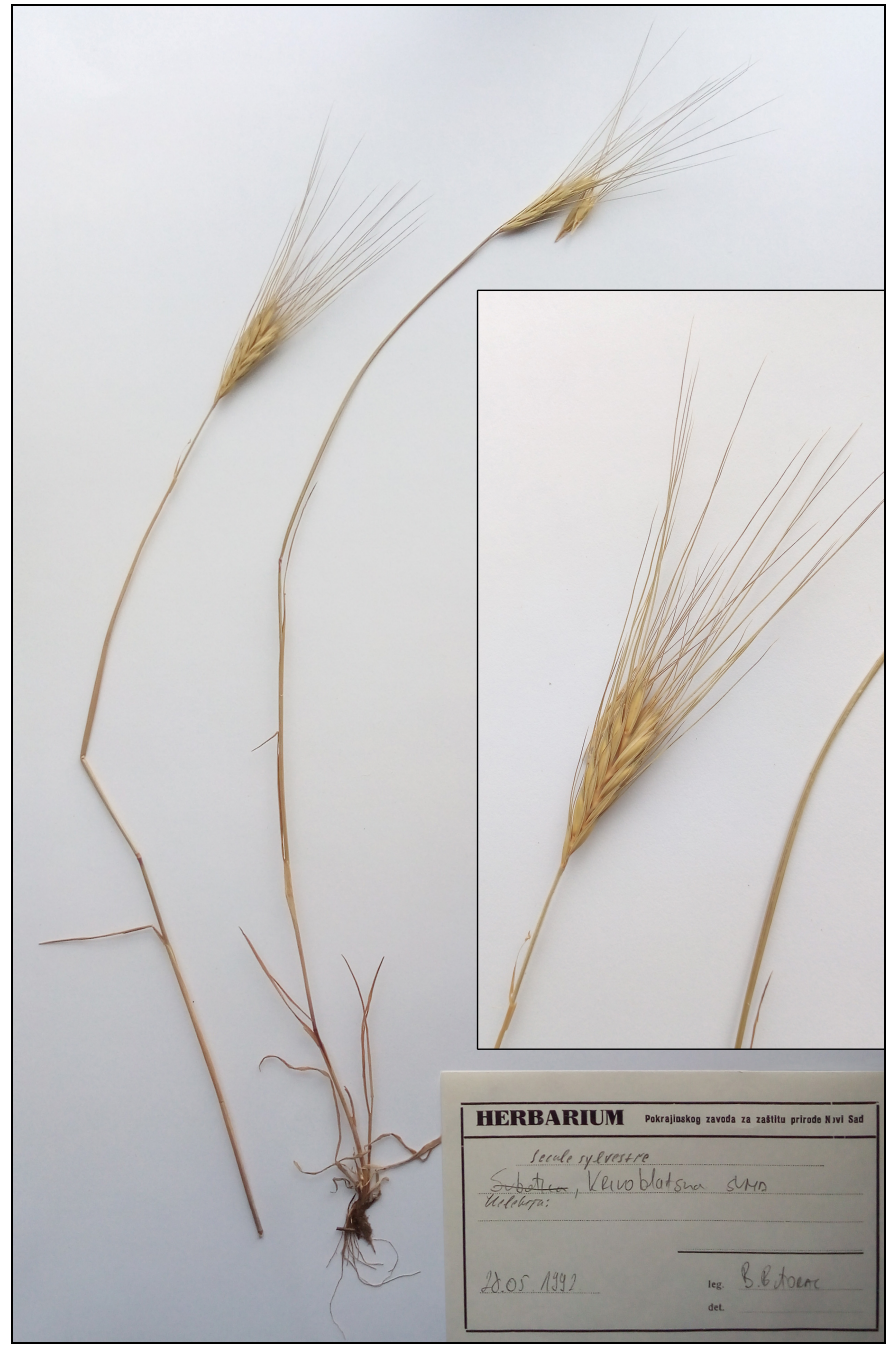

Fig. 27. - Secale sylvestre Host (Bačka, Subotica-Horgoš Sands) s.n. PZZP.

In Vojvodina this species was known as rare member of the vegetation of dry steppic grasslands. The majority of its historical records is confined to the Subotica-Horgoš Sands and to its immediate vicinity. Also the species was known to a lesser degree for similar habitats on Mt Fruška 
Gora, Titel hill and loess terrains near Bečej (Kupcsok 1914, Prodán 1910, 1915, Lányi 1914, Kovács 1915, Hirc 1919). Its last published records are more than 30 years old (Parabućski et al. 1986, Gajić 1986, Igić 1988).

\section{New records:}

Bačka, Subotica-Horgoš Sands, Kelebija: Čikerija, MGRS 34T CS80, coll. K. Sabadoš 31-May-2010, det. R. Perić (s.n. PZZP);

Bačka, Subotica-Horgoš Sands, Krivoblatska šuma, MGRS 34T CS91, coll. B. Butorac 28-May-1992, det. R. Perić (s.n. PZZP) (Fig. 27);

Bačka, Subotica-Horgoš Sands, Bački Vinogradi-Horgoš, Galamboš, MGRS 34T DS10, coll. et det. R. Perić 22-Sep-2007 (s.n. PZZP).

Banat, Deliblato Sands, Deliblato, MGRS 34T EQ06, coll. B. Miljković 1929, det. N. Jogan (s.n. BEO).

Confirmed species for the flora of Vojvodina province.

R. Perić, N. Jogan

Sesleria autumnalis (Scop.) F. W. Schultz, Arch. Fl.: 318 (1861).

First data on the presence of Sesleria autumnalis in Serbia originated from Pančić $(1856,1867)$, but he erroneously cited this taxon for Mt Rtanj and Mt Kopaonik (Bele Stene peak) (sub "S. elongata Host") and these records actually refer to $S$. latifolia (Adamović) Degen.

In fact, S. autumnalis was firstly found by Rudsky (1936) who described the community Seslerietum autumnalis Rudski on carbonate substrate of Mts. Šar-Planina (Mt Ošljak) in Kosovo and Metohija province. Blečić \& Tatić (1960) reported it from Mts. Šar-Planina (Mt Ostrovica) and Blečić \& Krasniqi (1971) for NW part of Mt Milanovac (Mrasarski steam, Labučevski stream, Koznik, Koznička Boka) on serpentinite geological substrate, respectively. Tatić (1976) in the Flora of SR Serbia also cited two main localities: Mt Milanovac (Koznik and Labučevski ["Labudovski"] stream) and Mts. Šar-Planina (Mt Ostrovica). However, there are no herbarium evidence of these records from ultramafic soil, so it is not excluded that they actually refer to $S$. latifolia which is common on serpentinites, and also found by us on Mt Ostrovica. There are several additional records on carbonate substrate from Kosovo and Metohija province (Krasniqi 1972, Rexhepi 1982). In Metohija (Mts. Prokletije) species is an edificator of the amphi-Adriatic (sub)montane hop-hornbeam forests on shallow soils, Seslerio-Ostryetum Ht. et H-ić 1950 (Krasniqi 1972). Some doubtful and erroneous data were reported from $\mathrm{W}$ and $\mathrm{C}$ Serbia (Gajić 1988, Rajevski 1951) (Fig. 28).

This late-blooming plant belongs to the group of nemoral oro(sub)mediterranean (W Balkan-Apenine) floristic elements. According to 
Valdés et al. (2009) it also includes W Mediterranean S. argentea (Savi) Savi. Sesleria autumnalis almost exclusively grows on carbonate bedrocks and the only known ultramafic habitats are situated in two localities in Albania, and also in aforementioned localities in Serbia (Kosovo and Metohija province), but these records are still unconfirmed.

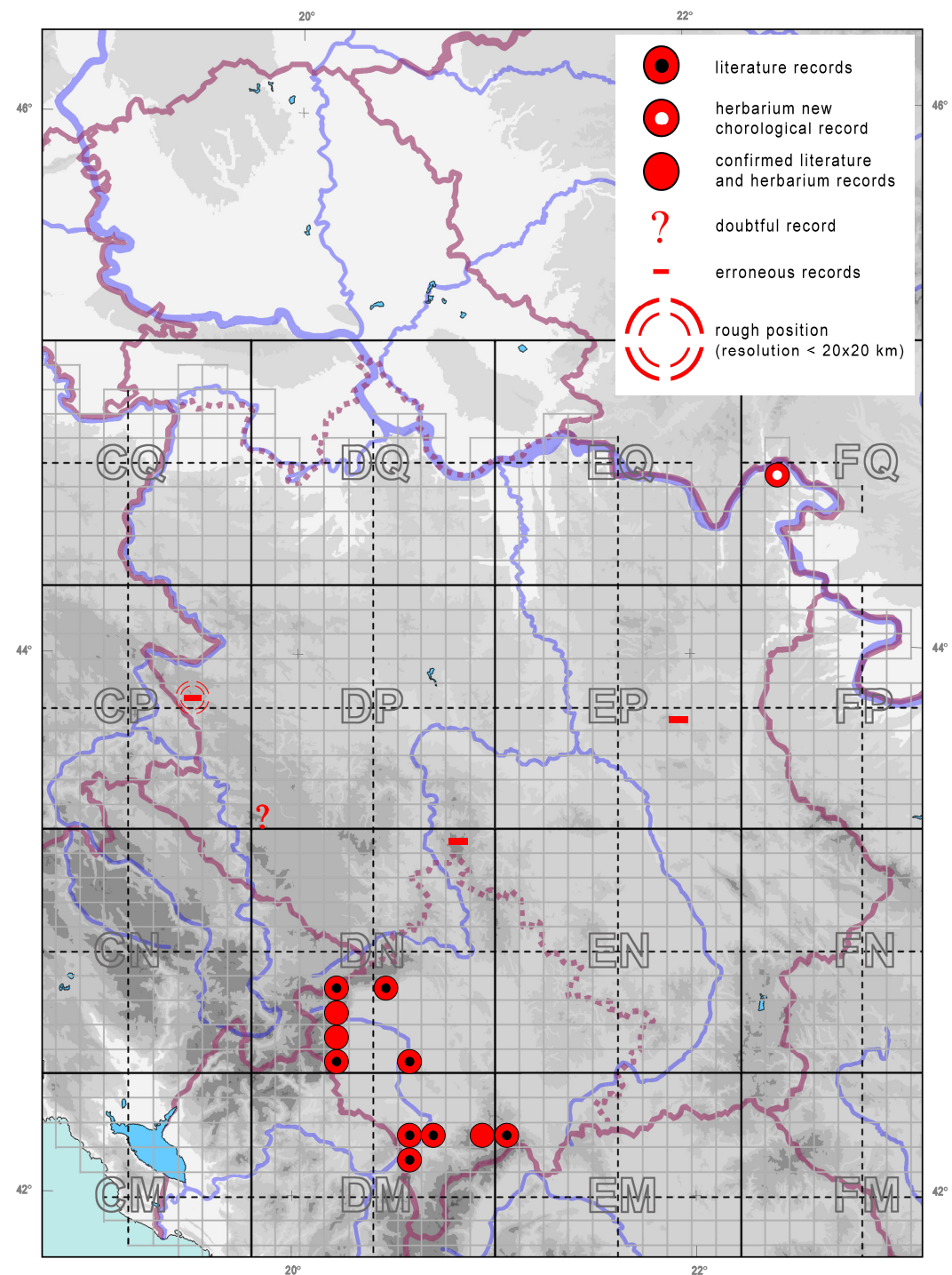

Fig. 28. - Distribution of Sesleria autumnalis (Scop.) F. W. Schultz in Serbia.

During the field survey of ultramafic flora in the vicinity of Tekija village in NE Serbia, at the foothill of Kustur hill, a small population of $S$. autumnalis was found on shallow soil and overgrown screes within 


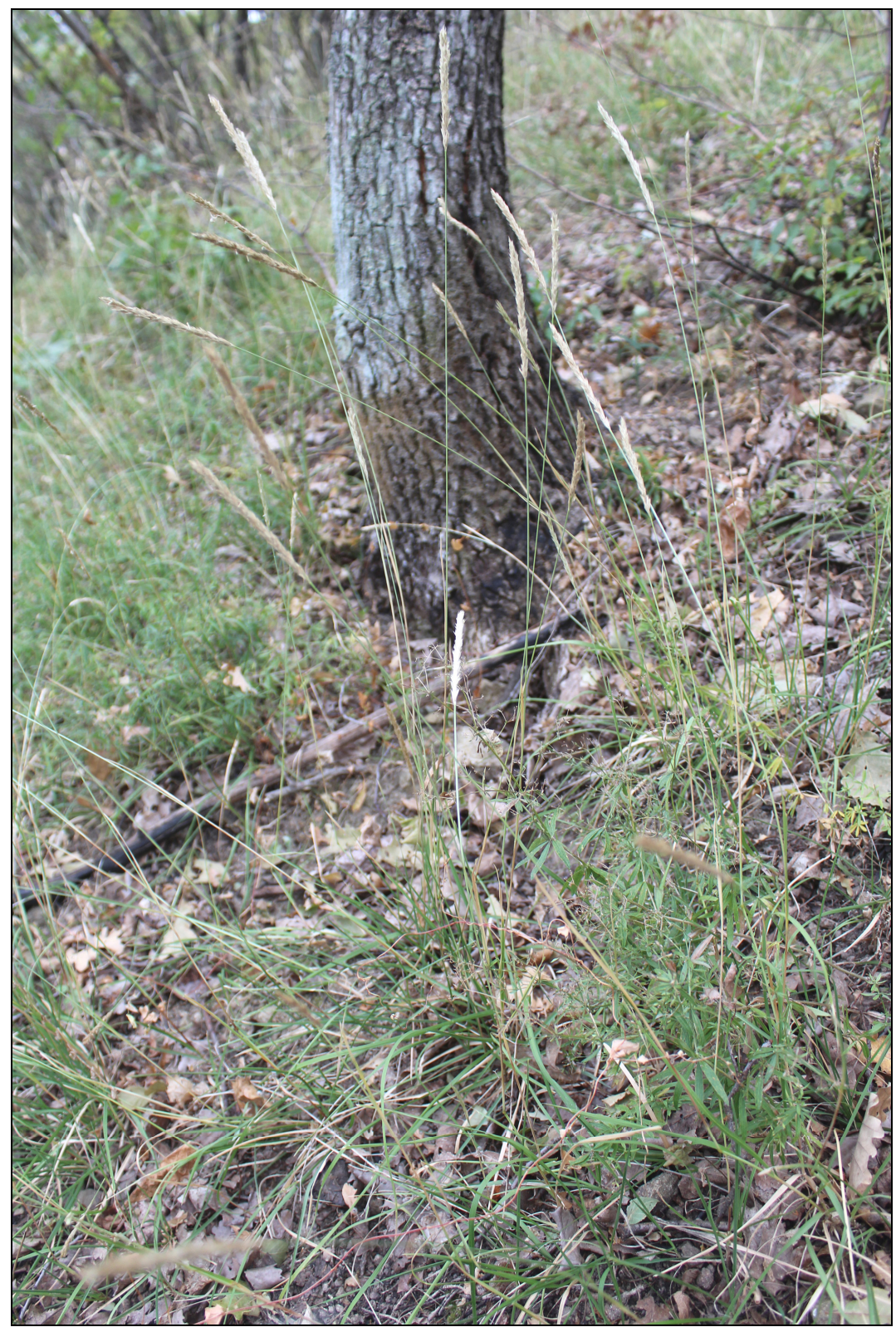

Fig. 29. - Sesleria autumnalis (Scop.) F. W. Schultz - plant near Tekija in NE Serbia (photo N. Kuzmanović).

Quercetum frainetto-cerridis Rudski (1940) 1949 forest. In this locality $S$. autumnalis is growing together with Carpinus orientalis Mill., Dactylis glomerata L., Euphorbia amygdaloides L., Festuca rubra L., Fraxinus ornus L., Galium aparine L., G. mollugo L., Melica uniflora Retz., Odontites vernus (Bellardi) Dumort., Quercus cerris L., Q. frainetto Ten., 
Q. petraea (Matt.) Liebl., Serratula tinctoria L., Sorbus domestica L., etc. (Figs. 29-30)

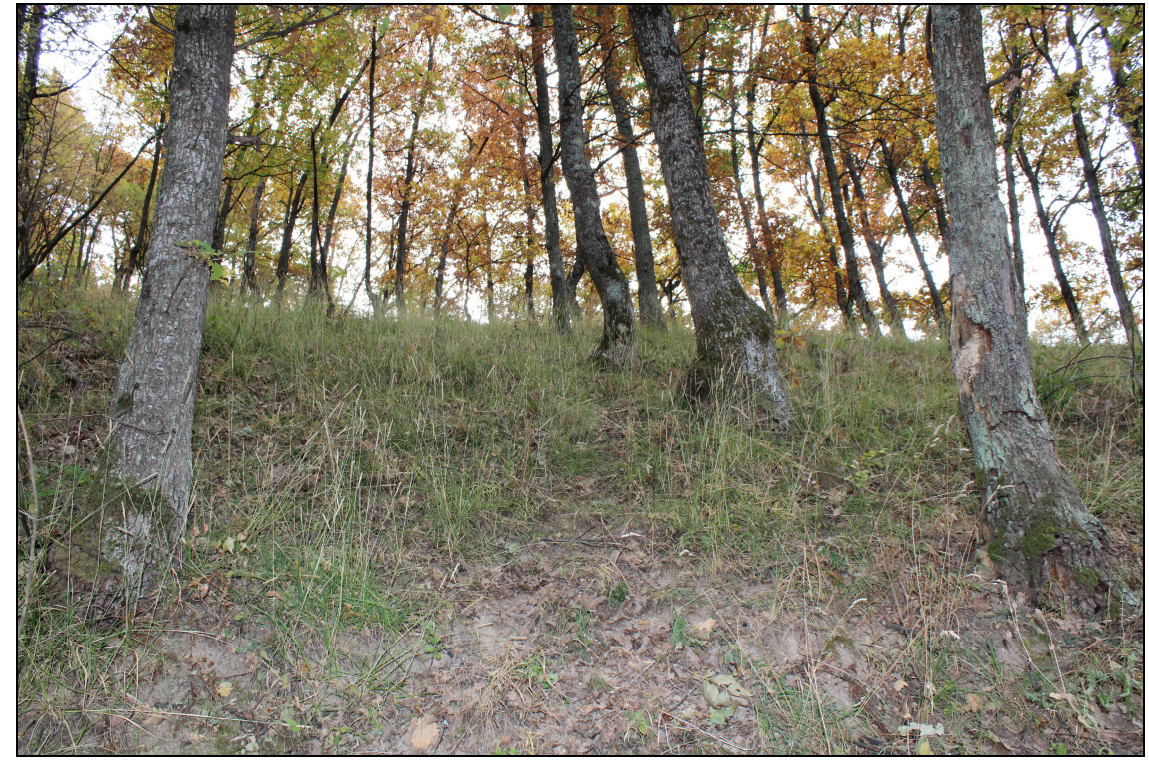

Fig. 30. - Sesleria autumnalis (Scop.) F. W. Schultz - plants in oak forest near Tekija in NE Serbia (photo N. Kuzmanović).

It seems that this Sesleria autumnalis population is edaphically confined to a very narrow ( $300 \mathrm{~m}$ wide) and isolated serpentinite belt surrounded by silicate (gneiss) and composite silicate (Sinaia Flysch) hilly massifs (Bogdanović et al. 1973). This is also the case with some adjacent communities and populations of different species in a given area. For example dry steppe-like grasslands with Scented Grass Chrysopogon gryllus (Teucrio chamaedrydis-Chrysopogonetum grylli Jovanović-Dunjić 1954) and several xerophilous associated plants [Achillea coarctata Poir., Asyneuma canescens (Waldst. \& Kit.) Griseb. \& Schenk, Campanula bononiensis L., Cytisus procumbens (Waldst. \& Kit. ex Willd.) Spreng., Serratula tinctoria L., Seseli annuum L.] were only found in this belt within a $5 \mathrm{~km}$ radius.

It is interesting to note that a newly discovered population of $S$. autumnalis near Tekija village is situated in the zone of harsh continental climate, more than $250 \mathrm{~km}$ away from the nearest one in Kosovo and Metohija province. The existence of such an extremely disjunctive population is certainly unexpected and can be explained by two possible scenarios. Since the population is very small and localized, and probably of clonal structure, it seems possible that the species was recently introduced in NE Serbia. The proximity of the Danube reservoir ("Đerdap Lake") and regional road (only $400 \mathrm{~m}$ away) points to long distance dispersal caused 
156 Niketić, M. et AL.: AnNOtated Checklist of VAscular Flora Of SERBia I

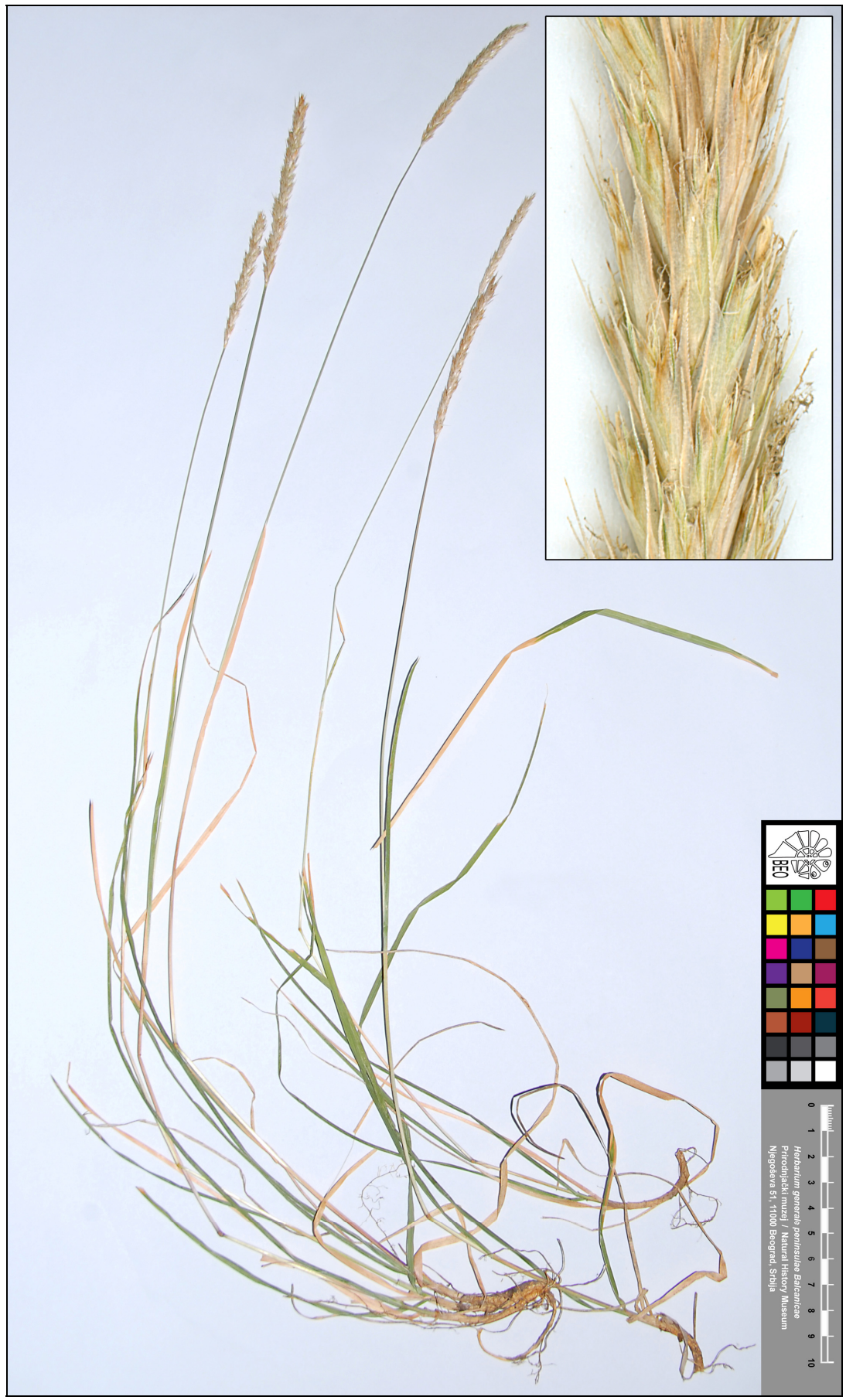

Fig. 31. - Sesleria autumnalis (Scop.) F. W. Schultz - herbarium specimens (NE Serbia, Tekija, BEO 82876). 
by accidentally human transportation. Climate extremes were tempered by reservoir which obtained favourable conditions for population survival. According to the second scenario, observed individuals represent the last remain of spatially and genetically isolated natural population. Ongoing molecular genetic studies will show which of these scenarios is more likely.

\section{First records for Serbia proper:}

NE Serbia, Donji Milanovac - Kladovo, Tekija, Misija, 170 m. s.m., Exp. N, serpentinite, overgrown screes in Quercetum frainetto-cerridis forest, MGRS 34T FQ14, coll. et det. M. Niketić 18-Sep-2018 (BEO 82880) (Fig. 31).

NE Serbia, Donji Milanovac - Kladovo, Tekija, Misija, 170 m. s.m., 22.397591 E, 44.673601 N, MGRS 34T FQ14, coll. et det. D. Lakušić, S. Vukojičić, N. Kuzmanović, I. Janković, T. Milekić 18-Oct-2018 (s.n. BEOU).

\section{New records for Kosovo and Metohija:}

Metohija, Mts. Prokletije, Mt Koprivnik, MGRS 34T DN31, DN32, coll. P. Černjavski Aug-1934, det. P. Černjavski 1940 (BEO 30756, 30761).

Metohija, Mts. Šar planina, Mt Kodža Balkan, Golem Bor, $1700 \mathrm{~m}$. s.m., MGRS 34T DM87, coll. et det. V. Stevanović 14-Sep-1997 (s.n. BEOU).

A new species for the flora of Serbia proper.

M. Niketić, D. Lakušić, N. Kuzmanović

Trisetum flavescens (L.) P. Beauv., Ess. Agrostogr.: 88 (1812) subsp. flavescens

Pančić (1883, 1884 sub Avena flavescens L.) provided first reports about this species in Serbia proper (Vlasina plateau - Bukova Glava peak; Vranje - Markovo Kale peak and Mts. Stara Planina - Vražja Glava peak). Adamović (1904) reported, besides Vranje (Markovo Kale peak), Vlasina plateau (Bukova Glava peak) and Mts. Stara Planina, one more locality near Surdulica settlement in SE Serbia.

First report on the presence of this grass in Vojvodina province was published by Godra (1873 sub Avena flavescens L.) for the steppe grass vegetation in Srem region.

The only precise data regarding its presence in Vojvodina province were published by Obradović (1966) for Mt Fruška Gora and Guelmino (1973) for Senta. 


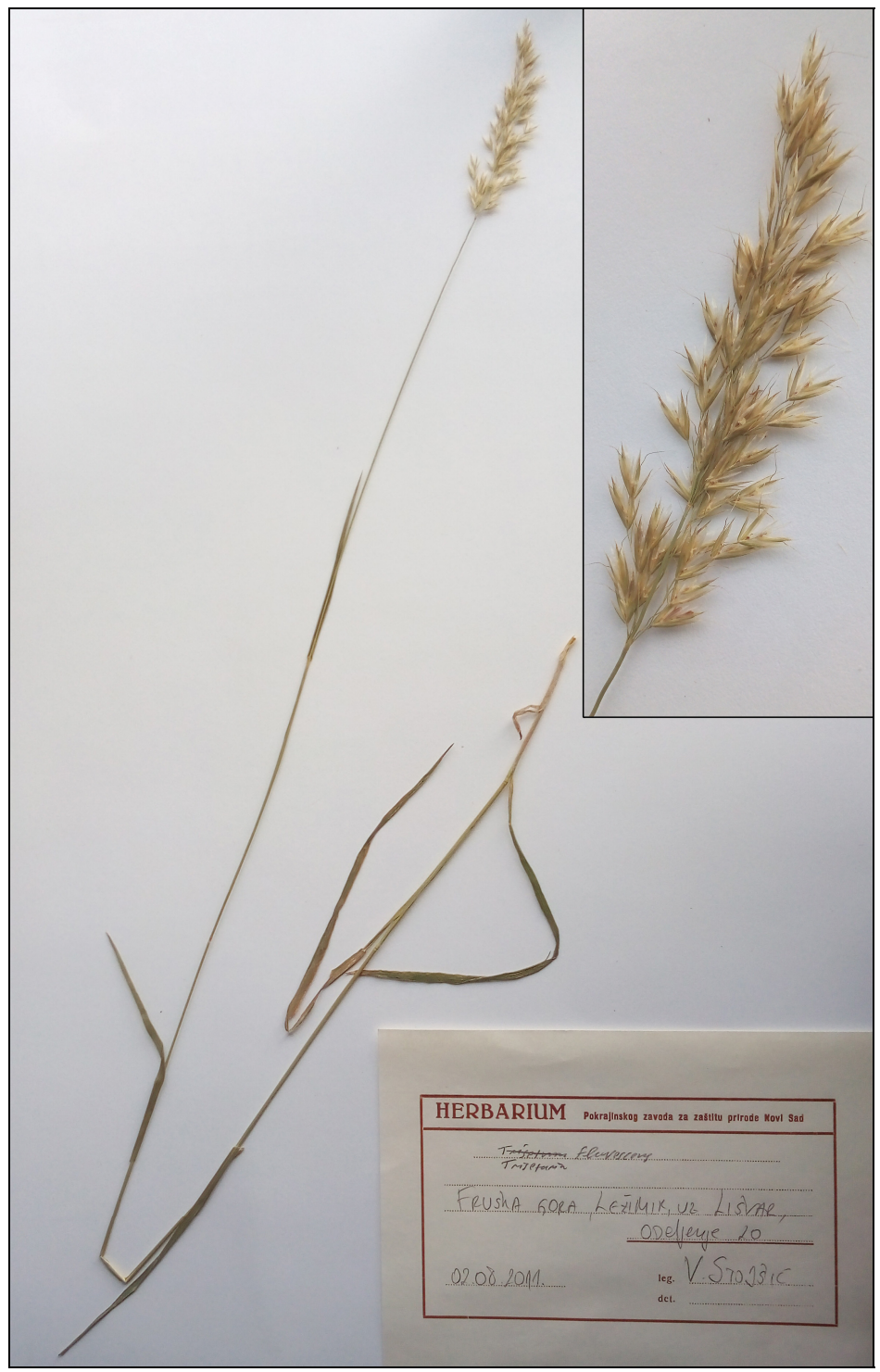

Fig. 32. - Trisetum flavescens (L.) P. Beauv. (Srem, Mt Fruška Gora, Ležimir) s.n. PZZP.

Bornmüller (1928) was the first one who found this species in Mts. ŠarPlanina (Mt Kobilica) in Kosovo and Metohija province.

In the Flora of SR Serbia (Cincović \& Kojić 1976) this plant was cited for the following localities: Šumadija region, Majdanpečka Domena, Veliki Pek river, Mts. Stara Planina, Mt Suva Planina, Vranje (Markov Kamen) and Pirot (Vražja Glava). In this reference, T. $f$. subsp. serbicum (Velen.) Hayek was also mentioned, but Cincović \& Kojić (1976) only claimed this 
statement "according to Hayek, it is present in Serbia". Later, Nikolić et al. (1986) provided several localities to complete the distribution of $T$. $f$. subsp. serbicum in Serbia proper: Mts. Stara Planina, Surdulica, Vlasina, Vranje (Markovo Kale peak).

\section{Some new records:}

Bačka, Kula, Lipar, Lipar loess valley, MGRS 34T CR86, CR96, coll. et det. R. Perić 16-Jun-2007 (s.n. PZZP).

Srem, Mt Fruška Gora, Ležimir, near Lišvar stream, MGRS 34T CR80, coll. V. Stojšić 02-Aug-2011, det. R. Perić (s.n. PZZP) (Fig. 32).

Srem, Mt Fruška Gora, Andrevlje, MGRS 34T CR90, coll. N. Andrejević 01-May-1969, det. N. Jogan (s.n. BUNS).

Srem, Petrovaradin, Širine, MGRS 34T DR10, coll. et det. M. Obradović 27-Sep-1964, (s.n. BUNS).

Srem, Beška, MGRS 34T DQ29, coll. et det. B. Butorac 02-Jun-1977, (s.n. BUNS).

Confirmed records for the flora of Vojvodina province.

R. Perić, N. Jogan

Triticum monococcum subsp. aegilopoides (Link) Thell., Naturwiss. Wochenschr., ser. 2, 17: 470 (1918).

= T. boeoticum Boiss., Diagn. P1. Orient. 13: 69 (1854).

Subspecies was firstly found by Pančić (1874 sub T. boeoticum Boiss.) near Aleksinac settlement and in Mt Rtanj and later by Petrović (1882 sub T. boeoticum Boiss.) in Sićevačka Gorge (Sićevo village) in E Serbia. Adamović [1904 sub T. m. var. boeoticum (Boiss.) Kneuck.] also found this plant near Aleksinac and in Mt Rtanj, but additionaly at the foothill of Mt Kopaonik (Kaznović village) and in the vicinity of Vranje (Preobraženje village).

Quite recently, this E Mediterranean plant was unofficially mentioned by Zlatković (2011 sub T. boeoticum Boiss.) for the Pčinja River Valley in SE Serbia.

\section{New record:}

SE Serbia, Pčinja River Valley, Brnjare village, dwarf annual grassland and abandoned arable land (Hordeo-Xeranthemetum annui), marl, clay and sandstone, $510 \mathrm{~m}$, MGRS 34T EM79, coll. et det. B. Zlatković 15Jul-2004, conf. N. Jogan (315 BEOU)

Confirmed record for the flora of Serbia (Fig. 33). 


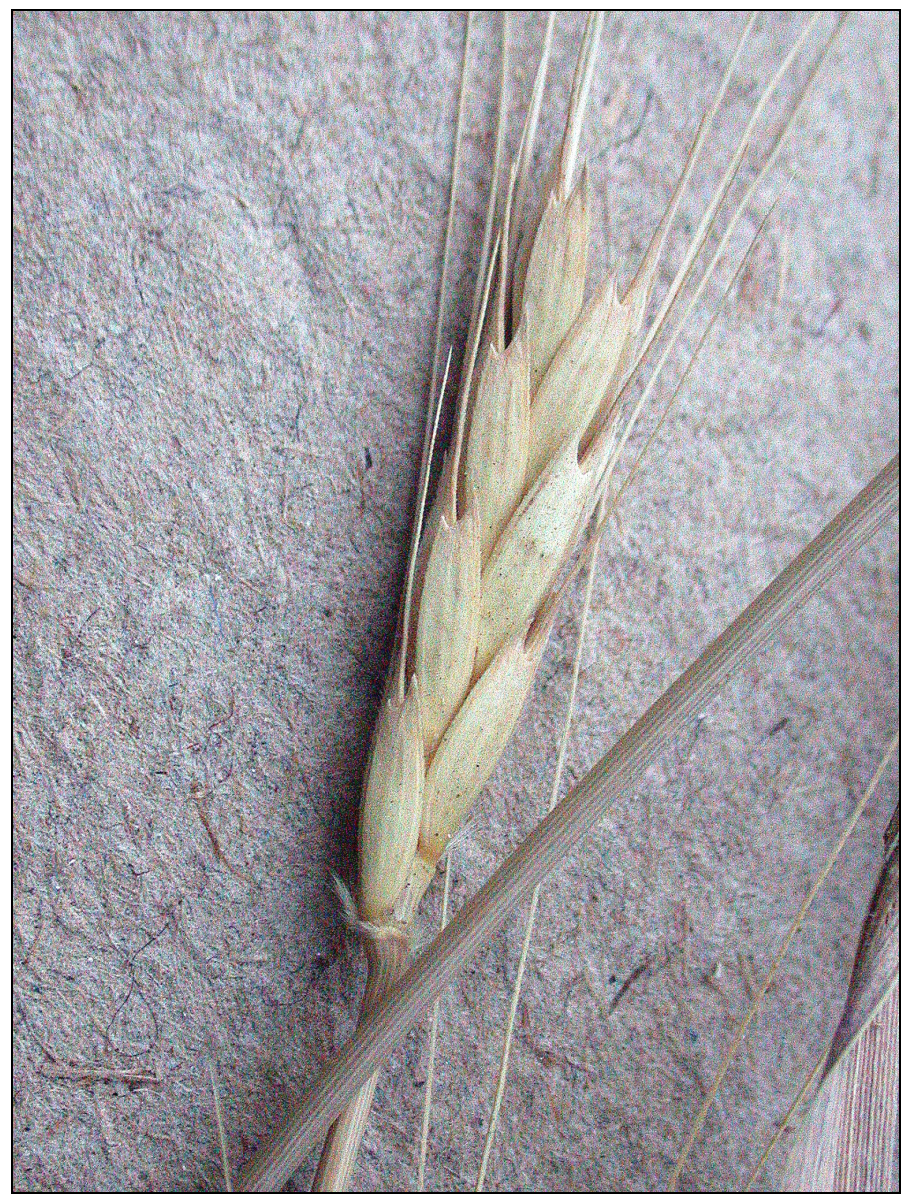

Fig. 33. - Triticum monococcum subsp. aegilopoides (Link) Thell. (SE Serbia, Pčinja River Valley, Brnjare) 315 BEOU.

B. Zlatković, N. Jogan

\section{Erroneously reported taxa for the flora of Serbia}

\section{LILIOPSIDA}

\section{CYPERACEAE}

Carex sempervirens Vill., Hist. Pl. Dauphiné 2: 214 (1787).

This species was firstly found in Mts. Šar-Planina (Mt Kobilica and Mt Ljuboten) in Kosovo and Metohija province by Grisebach (1846).

In the Flora of SR Serbia (Janković et al. 1976 sub C. s. subsp. sempervirens) this plant was published also for Kosovo and Metohija province (Mts. Prokletije - near Dečani and Mt Maja Rosulija and Mt Bogićevica) and for Serbia proper (Mts. Stara Planina). Nikolić et al. (1986 sub C. s. 
subsp. sempervirens) added one locality from Mts. Šar-Planina (between Stojkova Kuća and Mt Jezerska Čuka).

According to Jiménez-Mejías \& Luceño (2011) this high-mountain species does not grow in Serbia and literature records should be treated as erroneous and referred to C. bulgarica Velen. ("Niketić M. Unpublished. Checklist of Vascular Plants of Serbia").

M. Niketić

Carex tristis M. Bieb., Fl. Taur.-Caucas. 3: 615 (1819).

For the Serbia proper it was firstly reported by Adamović (1895) from Mts. Stara Planina, while for Kosovo and Metohija province Rechinger (1935) was the first botanist who claimed that he found it in Mts. Prokletije (Mt Kurvala and Mt Đeravica). In the Flora of SR Serbia [Janković et al. 1976 sub C. sempervirens subsp. tristis (M. Bieb.) Kük.] this plant was cited for Kosovo and Metohija province (Mts. Prokletije - Mt Kurvala and Mt Đeravica) and Serbia proper (Mt Suva Planina).

According to Koopman (2011) and Jiménez-Mejías \& Luceño (2011) this plant does not grow in Serbia, as well. Aforementioned records from the literature sources for $C$. tristis also should be treated as erroneous and referred to C. bulgarica Velen. ("Niketić M. Unpublished. Checklist of Vascular Plants of Serbia").

M. Niketić

\section{IRIDACEAE}

Iris aphylla L., Sp. Pl. 1: 38 (1753).

Pančić (1874 sub I. fieberi Seidl) was the first botanist who reported presence of this plant in Mts. Stara Planina (Rasovati Kamen peak). Later, Stjepanović-Veseličić [1976 sub I. aphylla var. fieberi (Seidl) Asch. \& Graebn.] and Lakušić (1999) took over the information from Pančić (1874) for the vicinity of Knjaževac (Mts. Stara Planina - Rasovati Kamen). Jávorka (1925) treated the record for Deliblatska Sands in Vojvodina province (sub $I$. hungarica) as doubtful and it probably corresponds to $I$. pumila $\mathrm{L}$.

Revision of Pančić's plant material (six exsiccata) from the Herbarium collection in Natural History Museum in Belgrade (BEO) and field investigation confirmed that in Rasovati Kamen peak does not grow $I$. aphylla. Pančić identified I. aphylla in two cases: BEO 01-127 (as $I$. fieberi) (Fig. 34) from Rasovati kamen and BEO 01-125 (as I. bohemica) from locality $10 \mathrm{~km}$ south of Rasovati Kamen. Morphology of the seeds and the capsules on both sheets corresponds to I. reichenbachii. However Pančić wrote on a separate label in the firs sheet: "culta - hort. Affinis 
graminea folia multo latiora". Since I. graminea was actually collected and deposited in another three sheets [BEO 01-114 (Fig. 35), BEO 01-117 (Fig. 36), BEO 01-119] and together with I. reichenbachii in the first one, some accidental material and label replacements probably took place in his collection. During the field excursion near Rasovati Kamen (10-Sep-2006) some individuals of I. graminea L. with very wide leaves were observed and collected. They corresponds to Carpatho-Balkanic I. graminea var.

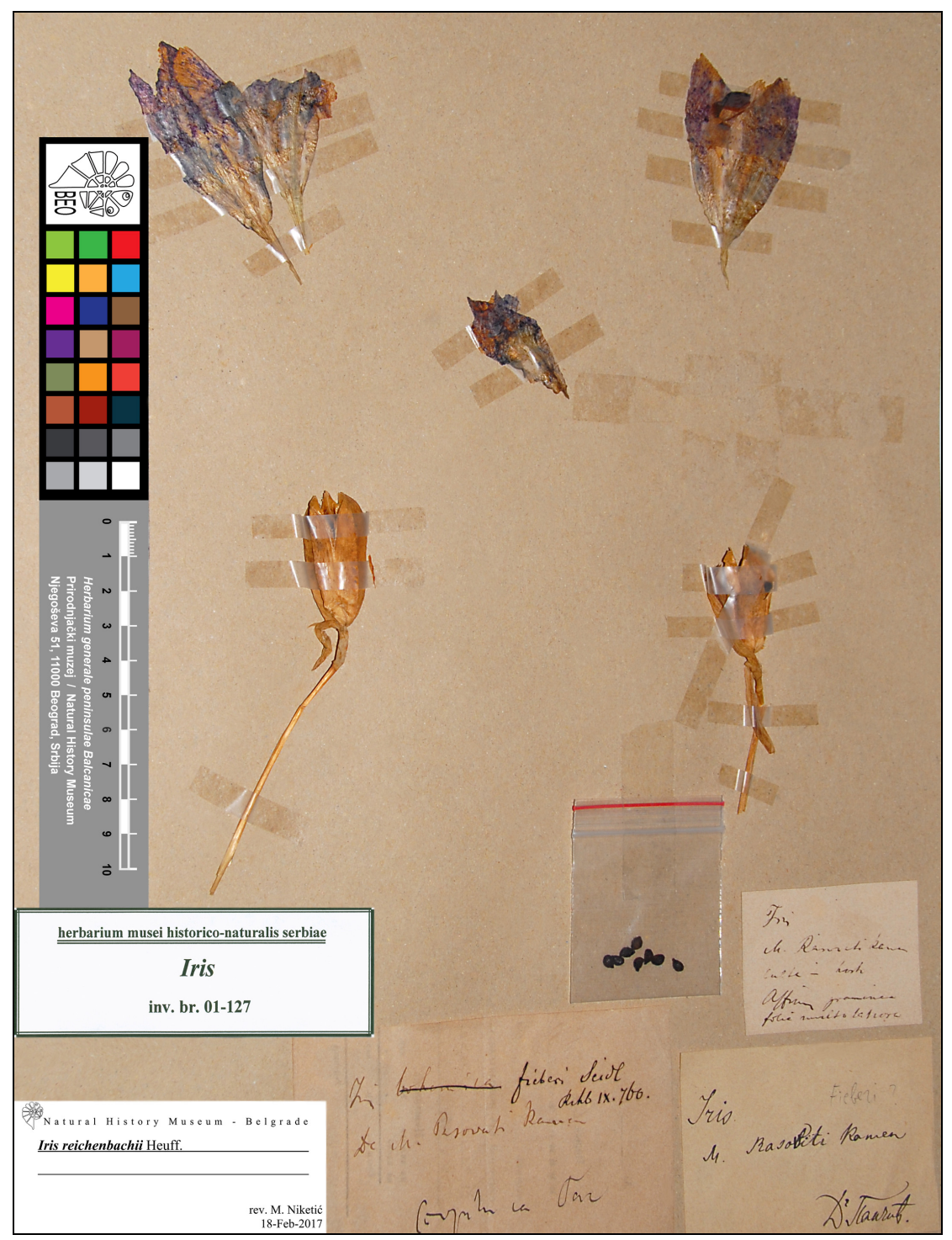

Fig. 34. - Iris reichenbachii Heuff. (E Serbia, Mts. Stara Planina, Rasovati Kamen, BEO 01-127) - original material of J. Pančić (identified as I. fieberi). 


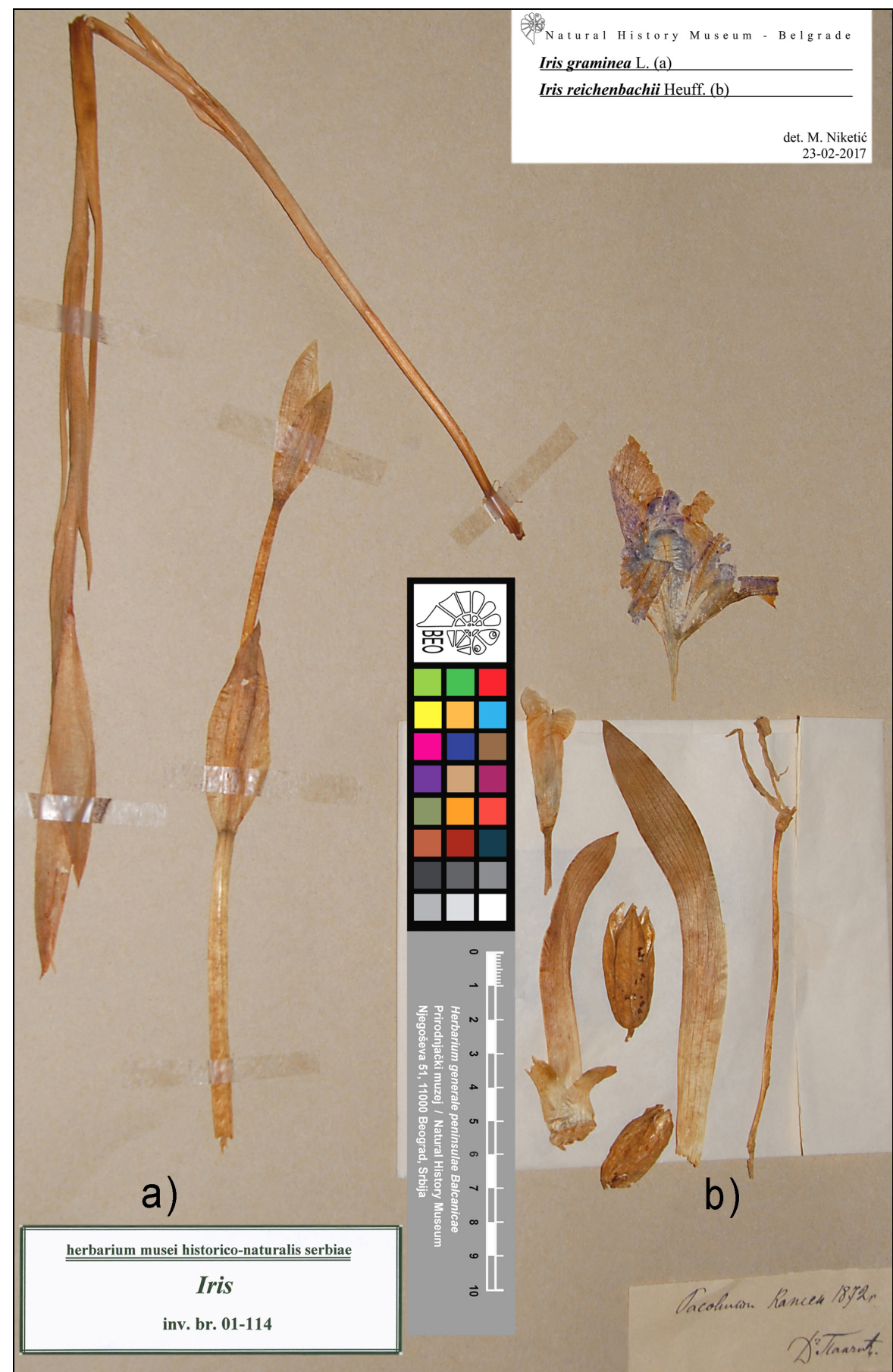

Fig. 35. - Iris graminea L. (a) and I. reichenbachii Heuff. (b) (E Serbia, Mts. Stara Planina, Rasovati Kamen, BEO 01-114) - original material of J. Pančić. 
164 Niketić, M. et al.: ANNOTAted Checklist of Vascular Flora of Serbia I

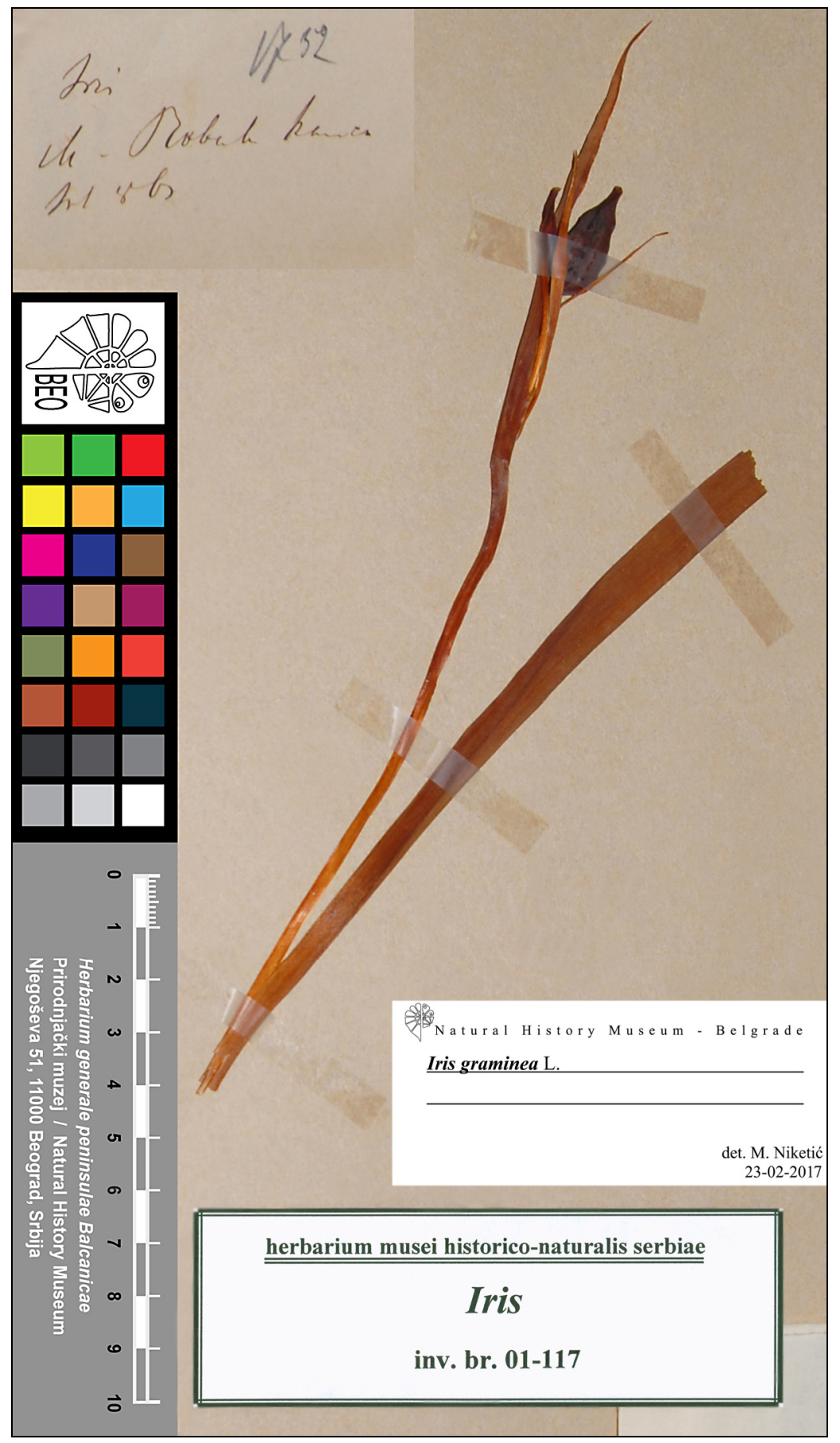

Fig. 36. - Iris graminea L. (E Serbia, Mts. Stara Planina, Rasovati Kamen, BEO 01-117) - original material of J. Pančić. 
latifolia Spach which some authors treat as a species (I. pseudocyperus Schur) or subspecies [I. graminea subsp. pseudocyperus (Schur) Soó].

The presence of I. aphylla on the Balkan Peninsula (Marinescu \& Alexiu 2013, Barker \& Govaerts 2018) also should be reconsidered. Prodán (1935) did not mention this species south of the Carpathians and according to Rechinger \& Randolph (1954) the area of the I. aphylla is shifted more to the north (of the Balkans) in comparison with that of the I. variegata L. Report from NE Albania (Markgraf 1931) is classified as casual remnants of cultivation (Barina 2017). According to Horvat \& Horvat (1962) old records from NW Croatia (Horvat 1938) actually correspond to the new species, Iris croatica Horvat \& M. D. Horvat. Further, old record for W Anatolia (Fischer \& Meyer 1854, Rechinger \& Randolph 1954) is treated as possible misidentification (Mathew 1984) and this species is also absent from the Alps (Rechinger \& Randolph 1954, Colasante \& Maury 2018). Presence for Russia and Transcaucasia (Barker \& Govaerts 2018) is also doubtful and requires verification. Consequently, the natural range of species would encompass the area of $\mathrm{C}$ Europe, from $\mathrm{C}$ Germany to the Carpathians, while other data for the southern regions probably correspond to cultivated plants.

\section{Specimens examined:}

Iris reichenbachii (harvested flowers and fruits) - E Serbia, Mts. Stara Planina, Rasovati Kamen, coll. et det. J. Pančić (sub I. fieberi „Affinis graminea folia multo latiora"), rev. M. Niketić 18-Feb-2017 (BEO 01127) (Fig. 34);

Iris graminea (before blossoming) \& I. reichenbachii (during blossoming and fructification) - E Serbia, Mts. Stara Planina, Rasovati Kamen, coll. J. Pančić 1872, det. M. Niketić 18-Feb-2017, BEO 01114) (Fig. 35);

Iris graminea (during fructification) - E Serbia, Mts. Stara Planina, Rasovati Kamen, coll. J. Pančić Jul-1863, det. M. Niketić 18-Feb-2017, BEO 01-117) (Fig. 36);

Iris graminea (during fructification) - E Serbia, Mt Svrljiške Planine, Pleš peak, coll. J. Pančić 1868 (in description: „Iris M. Rasovati kamen, M. Pleš..."), det. M. Niketić 18-Feb-2017, BEO 01-119);

I. reichenbachii (during fructification) - E Serbia, Mts. Stara Planina, Ivanova Livada, coll. et det. J. Pančić (sub I. bohemica), rev. M. Niketić 18-Feb-2017, BEO 01-125);

I. reichenbachii (during blossoming) - E Serbia, Mts. Stara Planina, Ivanova Livada, coll. J. Pančić (with description), det. M. Niketić 18Feb-2017, BEO 01-110). 
It is recommended to refer all the literature data for I. aphylla in Serbian flora either to I. reichenbachii (Serbia proper) or to I. pumila (Vojvodina).

\section{Niketić}

Iris foetidissima L., Sp. Pl. 1: 39 (1753).

First data on the presence of this C \& W Mediterranean plant comes from Pančić $(1856,1867)$ who claimed that he found it in Mt Starica near Majdanpek and in Mt Kopaonik, respectively. In the Flora of SR Serbia (Stjepanović-Veseličić 1976) this plant was treated as rare and distributed only at the foothill of Mt Starica near Majdanpek.

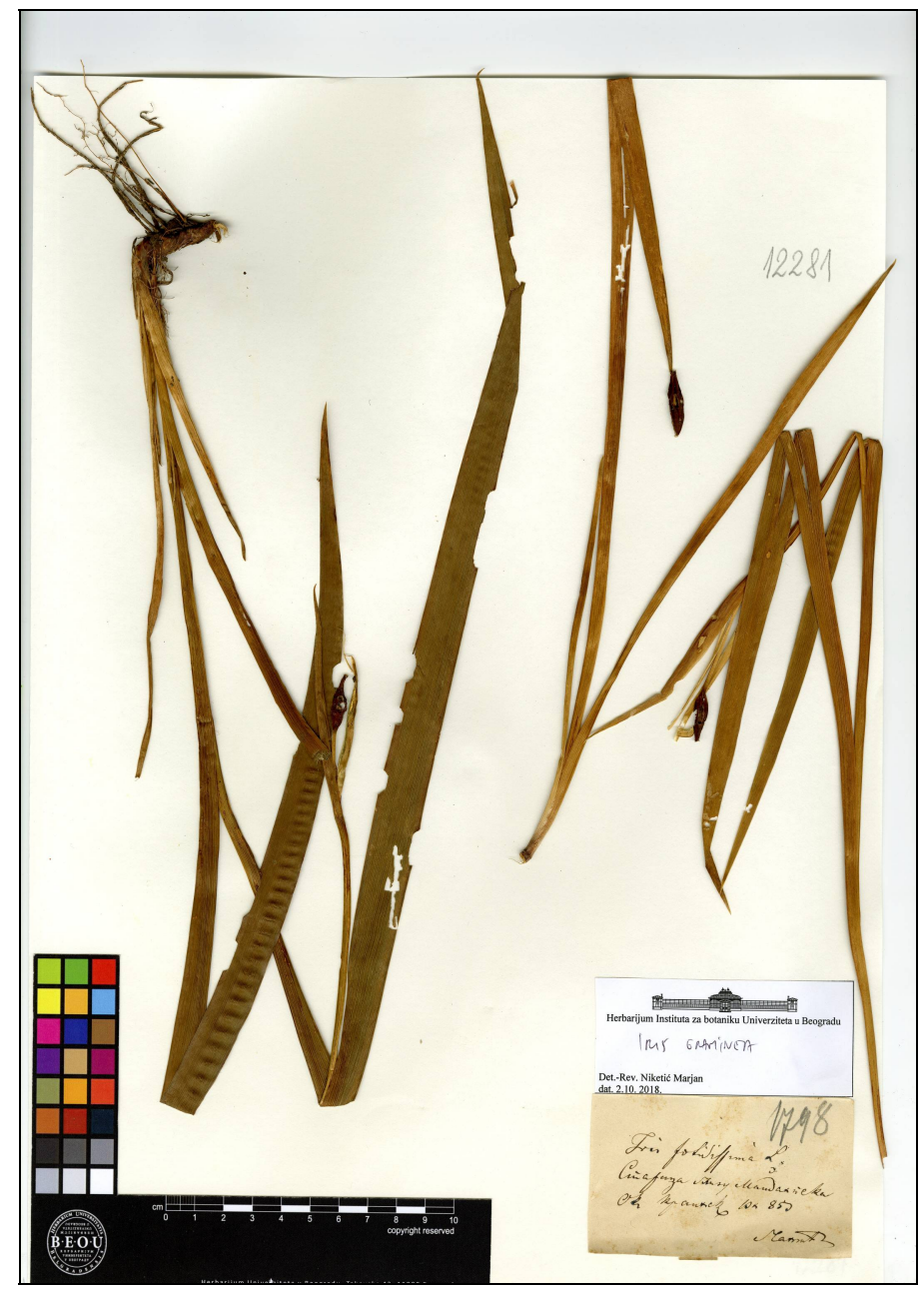

Fig. 37. - Iris graminea L. (NE Serbia, Mt Starica, BEOU 12281 ) - col. et det. J. Pančić (as I. foetidissima). 
Checking of Pančić's herbarium specimens has shown that these data actually correspond to I. graminea L. (Fig. 37). According to Euro+Med (2006-) and Colasante \& Maury (2018) this plant does not grow neither in former Jugoslavia (Ju) nor in the Balkan Peninsula as a whole. Consequently former literature data for Serbia should be attributed to I. graminea.

M. Niketić

\section{JUNCACEAE}

Luzula pallescens Sw., Summa Veg. Scand.: 13 (1814).

Duraki et al. (2017) published that they found this plant in Mts. ŠarPlanina in Kosovo and Metohija province. Since the plant specimen was checked in herbarium collection (BEOU) and revised, this records should be treated as erroneous and attributed to L. campestris (L.) DC. subsp. campestris.

\section{Niketić, Š. Duraki}

Luzula sudetica (Willd.) Schult., Oestr. Fl., ed. 2, 1: 573 (1814).

Grisebach (1846 sub L. nigricans Desv.) and Rechinger (1935) found this plant in Kosovo and Metohija province (Mts. Šar-Planina - Mt Kobilica and Mts. Prokletije - several localities, respectively). Pančić (1856) published the first record for the flora of Serbia proper in Mt Željin (sub $L$. nigricans Desv.).

According to Cincović \& Kojić (1976) this plants grows in Mt Kopaonik (Krčmar peak) in Serbia proper as well as in Mts. Prokletije (Mt Lumbardska Planina, Devojački Krš, Mt Kurvala, Mt Đeravica and Mt Koprivnik) in Kosovo and Metohija province.

Bačić et al. (2016) published results of cytogenetic analysis of the taxa that belong to Luzula sect. Luzula from the Balkan Peninsula, and concluded that L. sudetica was mostly confused with L. multiflora (Ehrh.) Lej. in the past, and quite recently with newly descibed $L$. exspectata Bačić \& Jogan from the SE Alps (Mts. Karavanke in Slovenia).

Therefore, according to these authors (Bačić et al. 2016), L. sudetica probably does not grow in Serbia and all literature records should be referred to L. exspectata Bačić \& Jogan.

M. Niketić

\section{LILIACEAE (COLCHICIACEAE)}

Colchicum hungaricum Janka, Term. Füz. 10: 75 (1886).

Refers to Colchicum doerfleri Halácsy (see on page 123).

B. Zlatković 
LILIACEAE (LILIACEAE)

Fritillaria messanensis subsp. gracilis (Ebel) Rix, Bot. J. Linn. Soc. 76: 356 (1978).

Refers to Fritillaria messanensis subsp. neglecta (Parl.) Nyman (see on page 125).

G. Tomović, M. Niketić

\section{POACEAE (GRAMINEAE)}

Avena barbata Pott ex Link, J. Bot. (Schrader) 1799(2): 315 (1800).

According to Valdés et al. [2009, sub Avena barbata subsp. lusitanica (Tab. Morais) Romero Zarco] this Mediterranean plant is present in Serbia and these authors cited Baum (1977) as a source for this record. However, in the last reference, there is no information on the presence of $A$. barbata in Serbia. For that reason, this record should be treated as misapplied name for which no corresponding taxon could be assumed.

\section{Acknowledgements}

M. Niketić

Nicholas Turland helped us to overcome certain nomenclature concerns. The Ministry of Education, Science and Technological Development of the Republic of Serbia supported this research through Grant 173030 "Plant biodiversity of Serbia and the Balkans - assessment, sustainable use and protection".

\section{REFERENCES}

Adamović, L. (1895): Stara planina. Prilog za poznavanje zemlje i stanovništva. Delo 7: 51-66.

Adamović, L. (1904): Revisio Glumacearum serbicarum. - Magyar Botanikai Lapok 3(3-5): 133-162.

Adamović, L. (1908): Flora Jugoistočne Srbije. - Rad Jugoslavenske akademije znanosti i umjetnosti 175 Matematičko-prirodoslovni razred 44: 153-214 [1-62].

Aggeenko, W. (1886): Addendum ad Chr. Steveni enumerationem plantarum in peninsula Taurica sponte crescentium. - Scripta Botanica Horti Universitatis Imperialis Petropolitanae 1: 290-292.

Amarell, U., Hoffer-Massards, F., Röthlisberger, J. (2014): Panicum barbipulvinatum Nash (=Panicum riparium $\mathrm{H}$. Scholz). Eine übersehene Art in der Schweiz. - Bauhinia 25: 55-78.

Anačkov, G. (2009): Taksonomija i horologija roda Allium L. 1754 (Amaryllidales, Alliaceae) u Srbiji. Doktorska disertacija. - Departman za biologiju i ekologiju, Prirodno-matematički fakultet, Univerzitet u Novom Sadu, Novi Sad, 253 pp. (manuscr.). 
Anagnou-Veroniki, M., Papaioannou-Souliotis, P., Karanastasi, E., Giannopolitis, C. N. (2008): New records of plant pests and weeds in Greece, 1990-2007 (2008). - Hellenic Plant Protection Journal 1: 55-78.

Anonymous (2010-2016): Rulebook on declaration and protection of protected and strictly protected species of plants, animals and fungi. - Official Gazette of the Republic of Serbia, No. 5/10; 88/10; 91/10; 47/11; 14/16; 98/16.

APG IV (2016): An update of the Angiosperm Phylogeny Group classification for the orders and families of flowering plants: APG IV. - Botanical Journal of the Linnean Society 181: 1-20.

Barker, C., Govaerts, R. (2018): Iridaceae. In: World Checklist of Arecaceae. Royal Botanic Gardens, Kew. [http://wcsp.science.kew.org/]

Bačić, T., Frajman, B., Dolenc Koce, J. (2016): Diversification of Luzula sect. Luzula (Juncaceae) on the Balkan Peninsula - a cytogenetic approach. - Folia Geobotanica 51(1): 51-63.

Barina, Z., Rakaj, M., Pifkó, D. (2013): - Contributions to the flora of Albania, 4 Willdenowia 43(1): 165-184.

Barina, Z. (ed.) (2017): Distribution atlas of vascular plants in Albania. Hungarian Natural History Museum, Budapest.

Barina, Z., Somogyi, G., Pifkó, D., Rakaj, M. (2018): Checklist of vascular plants of Albania. - Phytotaxa 378(1): 1-339.

Bartolucci, F., Peruzzi, L., Galasso, G., Albano, A., Alessandrini, A., Ardenghi, N. M. G., Astuti, G., Bacchetta, G., Ballelli, S., Banfi, E., Barberis, G., Bernardo, L., Bouvet, D., Bovio, M., Cecchi, L., Di Pietro, R., Dominao, G., Fascetti, S., Fenug, G., Festi, F., Foggi, B., Gallo, L., Gottschlich, G., Gubellini, L., Iamonico, D., Iberite, M., Jiménez-Mejías, P., Lattanzi, E., Marchetti, D., Martinetto, E., Masin, R. R., Medagli, P., Passalacqua, N. G., Peccenini, S., Pennesi, R., Pierini, B., Poldini, L., Prosser, F., Raimondo, F. M., RomaMarzio, F., Rosati, L., Santangelo, A., Scoppola, A., Scortegagna, S., Selvaggi, A., Selvi, F., Soldano, A., Stinca, A., Wagensommer, R. P., Wilhalm, T., Conti, F. (2018): An updated checklist of the vascular flora native to Italy. Plant Biosystems 152(2): 179-303.

Bateman, R. M., Molnár, A. V., Sramkó, G. (2017): In situ morphometric survey elucidates the evolutionary systematics of the Eurasian Himantoglossum clade (Orchidaceae: Orchidinae). - PeerJ DOI 10.7717/peerj.2893: 83 pp.

Baum, R. B. (1977): Oats: wild and cultivated: a monograph of the genus Avena L. (Poaceae). - Biosystematics Research Institute, Canada Department of Agriculture, Research Branch, Ottawa, 463 pp.

Bizot, A., Pétrement, B. (2010): Equisetum ×moorei Newman, un nouvel hybride d'Equisetum du subg. Hippochaete, mis en évidence dans une carrière à Etalle (Province de Luxembourg, Belgique). - Adoxa 64: 1-5.

Bizot, A., Pétrement, B., Krippel, Y. (2012): Equisetum $\times$ moorei Newman (Equisetaceae, Pteridophyta), taxon nouveau pour le Luxembourg. - Bulletin de la Société des naturalistes luxembourgeois 113: 83-90.

Blečić, V., Krasnići, F. (1971): Zajednica endemičnog šibljaka forzicije i krstušca (Polygalo-Forsythietum europaeae Blečić i Krasnići) u jugozapadnoj Srbiji. - 
Glasnik Republičkog zavoda za zaštitu prirode i prirodnjačkog muzeja u Titogradu 4: $35-40$.

Blečić, V., Tatić, B. (1960): Beitrag zur Kenntniss der Panzerföhrenwälder der Gebirge Ostrovica. - Glasnik Botaničkog zavoda i bašte Univerziteta u Beogradu 1(2): 131-139.

Bogdanović, P., Marković, V., Dragić, D., Rakić, M., Babović, M., Rajčević, D., Popović, V., Milojević, Lj. (1973): Osnovna geološka karta SFRJ 1:100 000, list Donji Milanovac. - Savezni geološki zavod, Beograd.

Bornmüller, J. (1928): Beiträge zur Flora Mazedoniens III. - Botanische Jahrbücher fur Systematik, Pflanzengeschichte und Pflanzengeographie 41(140): 1-196.

Boué, A. (1840): La Turquie d' Europe. Observations sur la géographie, la géologie, l'histoire naturelle, la statistique, les moeurs, les coutumes, l'archéologie, l'agriculture, l'industrie, le commerce, les gouvernements divers, le clergé, l'histoire et l'état politique de cet empire 1: 526 pp. - A. Bertrand, Paris.

Brickell, C. D. (1980): Colchicum L. In: Tutin, T. G. et al. (eds.): Flora Europaea 5: 21-25. - University Press, Cambridge.

Budak, V. (1998): Flora i biljnogeografske odlike flore slatina Bačke. - Matica srpska, odeljenje za prirodne nauke, Novi Sad. 194 pp.

Christenhusz, M., Raab-Straube, E. (2013): Polypodiopsida. In: Euro+Med Plantbase - the information resource for Euro-Mediterranean plant diversity [http:// ww2.bgbm.org/EuroPlusMed/PTaxonDetail.asp?NameId=44460\&PTRefFk=7 500000] (retrieved October $6^{\text {th }}$ 2018).

Christenhusz, M. J. M., Reveal, J. L., Farjon, A., Gardner, M. F., Mill, R. R., Chase, M. W. (2011): A new classification and linear sequence of extant gymnosperms. - Phytotaxa 19: 55-70.

Cincović, T., Kojić, M. (1976): Poaceae [p.p. maj.]. In: Josifović, M. (ed.): Flora SR Srbije 8: 259-472. - Srpska akademija nauka i umetnosti, Beograd.

Clayton, W. D., Govaerts, R., Harman, K. T., Williamson, H., Vorontsova, M. (2018): World Checklist of Poaceae. - Royal Botanic Gardens, Kew. [http:// wcsp.science.kew.org/] (retrieved October $6^{\text {th }} 2018$ )

Colasante, M. A., Maury, A. E. (2018): Iridaceae Present in Italy. - Sapienza Univerzità Editrice, Roma.

Christenhusz, M., Raab-Straube, E. (2013): Polypodiopsida. In: Euro+Med Plantbase - the information resource for Euro-Mediterranean plant diversity [http:// ww2.bgbm.org/EuroPlusMed/PTaxonDetail.asp?NameId=44460\&PTRefFk=7 500000] (retrieved October $6^{\text {th }}$ 2018).

Csiky, J., Király, G., Oláh, E., Pfeiffer, N., Virók, V. (2004): Panicum dichotomiflorum Michaux., a new element in the Hungarian flora. - Acta Botanica Hungarica 46(1-2): 137-141.

Čapaković, J. (1983): Alliaceae. In: Gajić M. (ed.): Flora Deliblatske peščare: 346348. - Institut za biologiju PMF Novi Sad, Šumsko-industrijski Kombinat "Pančevo”, Specijalni rezervat prirode „Deliblatski pesak“, Novi Sad.

Damanakis, M., Scholz, H. (1990): Phytogeographical notes on the Poaceae of Greece. - Willdenowia 19: 413-423. 
Diklić, N. (1975): Liliaceae. In: Josifović, M. (ed.): Flora SR Srbije 7: 492-568. Srpska akademija nauka i umetnosti, Beograd.

Diklić, N. (1976): Orchidaceae. In: Josifović, M. (ed.): Flora SR Srbije 8: 36-116. - Srpska akademija nauka i umetnosti, Beograd.

Dimopoulos, P., Raus, Th., Bergmeier, E., Constantinidis, Th., Iatrou, G., Kokkini, S., Strid, A., Tzanoudakis, D. (2013): Vascular plants of Greece: An annotated checklist. Botanischer Garten und Botanisches Museum, Berlin-Dahlem; Hellenic Botanical Society, Athens. 372 pp.

Duraki, Š., Stanojević, M., Stojanović, M. (2017): Florističke karakteristike šarplaninskog grebena Kobilica. - Zaštita prirode 67(1-2): 5-23.

Euro+Med (2006-): Euro+Med PlantBase - the information resource for EuroMediterranean plant diversity. Published on the Internet http://ww2.bgbm.org/ EuroPlusMed/ [accessed October $6^{\text {th }}$ 2018].

Fischer, F. E. L., Meyer, C. A. (1854): Plantes nouvelles recueillies par M. de Tchihatcheff, en Asie mineure pendant l'année 1849. - Annales des Sciences Naturelles 4(1): 30-36.

Fritsch, C. (1909): Neue Beiträge zur Flora der Balkan-halbinsel, insbesonders Serbiens, Bosniens und der Herzegovina. I. - Mitteilungen des Naturwissenschaftlichen Vereines für Steiermark 45(1): 131-183.

Futák, J. (1966): Equisetopsida. In: Futák, J. (ed.): Flóra Slovenska 2: 47-83. Slovenská Akadémia Vied, Bratislava.

Gajić, M. (1986): Flora i vegetacija Subotičko-horgoške peščare. - Šumarski fakultet Beograd, Šumsko gazdinstvo Subotica.

Gajić, M. (1988) (ed.): Flora Nacionalnog parka Tara. - Šumarski fakultet, Beograd.

G.I.R.O.S. (2009): Orchidee d'Italia - Guida alle orchidee spontanee. - Il Castello, Cornaredo, Milano.

Godra, B. (1872): Flora des Peterwardeiner Grenz - Regiments Nr. 9. - Österreichische botanische Zeitschrift 22: 98-100, 133-135, 163-166, 201-206, 228-231, 266-270, 292-297.

Godra, B. E. (1873): Monographie von Syrmien. - I. C. Soppron, Zemun ["Semlin"].

Govaerts, R., Bernet, P., Kratochvil, K., Gerlach, G., Carr, G., Alrich, P., Pridgeon, A. M., Pfahl, J., Campacci, M. A., Holland Baptista, D., Tigges, H., Shaw, J., Cribb, P., George, A., Kreuz, K., Wood, J. (2018): World Checklist of Orchidaceae. - Royal Botanic Gardens, Kew. [http://wcsp.science.kew.org/] (retrieved October $6^{\text {th }}$ 2018).

Grinţescu, G. (1952): Equisetum L. In: Săvulescu, T. (ed.): Flora Republici Populare Române 1: 46-73. - Academia Republici Populare Române, Bucureşti.

Grisebach, A. (1846): Spicilegium Florae rumelicae et bithynicae exhibens synopsin plantarum quas in aest. 1839 legit auctor A. Grisebach. 2: 161-548. Fridericus Vieweg et filius, Braunschweig ["Brunsvigae"].

Guelmino, J. (1968): Zenta és környékének növényei. I. Virágosok. Građa za Monografiju Sente br. 12. - Novi Sad, Senta. 
Guelmino, J. (1973): Zenta és könyékenevk növényei. II. Virágtalanok. Građa za monografiju Sente. 12/B: 39-103, Senta.

Hájek, M., Hájková, P., Apostolova, I. (2005): Notes on the Bulgarian wetland flora, including new national and regional records. - Phytologia Balcanica 11(2): 173-184.

Hayek, A. (1924): Zweiter Beitrag zur Kenntnis der Flora von Albanien. Denkschriften der Kaiserlichen Akademie der Wissenschaften, MathematischNaturwissenschaftliche Classe 99: 101-223.

Hegi, G. (1935): Illustrierte Flora von Mitteleuropa I (ed. 2). - Aufl. Carl Hanser Verl., München.

Hirc, D. (1919): Građa za floru srijemskog plošnjaka, Fruške gore i okoline grada Osijeka. - Glasnik Zemaljskog muzeja u Bosni i Hercegovini 31: 359-408.

Hoppe, D. H. (1819): Botanische Notizen. - Flora (Regensburg) 2(12): 182-189.

Horvat, I. (1938): Zaštita Zelenjaka kod Klanjca. - Zaštita prirode 1: 99-100.

Horvat, I., Horvat. M. (1962): Iris croatica - A New Species of Iris from Croatia - Acta Botanica Croatica 20-21: 8.

Hulina, N. (1985): Species Panicum dichotomiflorum Michx. - new weed in Jugoslavia. - Fragmenta Herbologica Jugoslavica 14(1-2): 113-120. (in Croatian with English abstract)

Humphries, C. J. (1980): Hordeum L. In: Tutin, T. G., Heywood, V. H., Burges, N. A., Moore, D. M., Valentine, D. H., Walters, S. M., Webb, D. A. (eds.): Flora Europaea 5: 204-205. - Cambridge University Press, Cambridge.

Igić, R. (1988): Pregled flore Titelskog brega. - Matica srpska, zbornik za prirodne nauke 74: $135-152$.

Janković, M. (1982): Prilog poznavanju vegetacije Šarplanine sa posebnim osvrtom na neke značajnije reliktne vrste biljaka. - Glasnik Instituta za botaniku i Botaničke bašte Univerziteta u Beogradu (13)15(1-3): 75-129.

Janković, M. M., Čanak, M., Jovanović, R. (1976): Cyperaceae. In: Josifović, M. (ed.): Flora SR Srbije 8: 151-259. - Srpska akademija nauka i umetnosti, Beograd.

Jávorka, S. (1925): Magyar Flóra (Flora hungarica). Magyarorsag viragos es edenyes viragtalan novenyeinek meghatarozo kezikonyve. - Studium, Budapest.

Jávorka, S., Degen, A., Gáyer, Gy., Soó, R., Trautmann, R., Zahn, K. H. (1926): Anthophyta [In: Csiki, E., Jávorka, S., Kümmerle, J. B: Adatok Albánia flórájához]. In: Teleki, P., Csiki, E. (eds.): A Magyar tudományos akadémia Balkán-Kutatásainak Tudományos Eredményei 3: 219-346. - A Magyar Tudományos Akadémia Kiadása, Budapest.

Jiménez-Mejías, P., Luceño, M. (2011): Cyperaceae. In: Euro+Med Plantbase. [http://ww2.bgbm.org/EuroPlusMed/PTaxonDetail.asp?NameCache=Carex \%2 0sempervirens\&PTRefFk=7400000] (retrieved October $6^{\text {th }} 2018$ ).

Jogan, N. (1990): A contribution to the knowledge of the distribution of grasses in Slovenia. - Biološki Vestnik 38(2): 27-38. (in Slovenian with English abstract)

Jogan, N., Martinčić, A. (eds) (2015): New localities 36. - Hladnikia 36: 59-74. (in Slovenian with English abstract) 
Jovanović, B. (1955): Šumske fitocenoze i staništa Suve planine. - Glasnik Šumarskog fakulteta 9: 3-101.

Jovanović, B. (1970): Gymnospermae. In: Josifović, M. (ed.): Flora SR Srbije 1: 125-166. - Srpska akademija nauka i umetnosti, Beograd.

Jovanović, B. (1992): Coniferales. In: Sarić, M. (ed.): Flora Srbije 1: 168-234. Srpska akademija nauka i umetnosti, Beograd.

Jovanović, S. (1999): Asparagus pseudoscaber Grec. In: Stevanović, V. (ed.): Crvena knjiga flore Srbije 1. Iščezli i krajnje ugroženi taksoni: 273-274. Ministarstvo za životnu sredinu Republike Srbije, Biološki fakultet Univerziteta u Beogradu, Zavod za zaštitu prirode Republike Srbije, Beograd.

Kalinowski, P., Sliwinska, E., Kruk, J. (2016): Equisetum ×moorei Newman (Equisetaceae) - a 'new' nothotaxon in the Polish flora. - Biodiversity: Research and Conservation 41: 11-18.

Kamari, G., Phitos, D. (2006): Karyosystematic study of Fritillaria messanensis s.1. (Liliaceae). - Willdenowia 36: 217-233.

Király, G., Alegro, A. (2015): Re-evaluation of the Panicum capillare complex (Poaceae) in Croatia. - Acta Botanica Croatica 74(1): 173-179.

Király, G., Baranyai-Nagy, A., Kerekes, Sz., Király, A., Korda, M. (2009): Additions to the knowledge of the alien flora of Hungary. - Flora Pannonica 7: 3-31. (in Hungarian with English abstract)

Kirschner, J. (1991): An account of natural hybridization within Luzula sect. Luzula (Juncaceae) in Europe. - Preslia 63: 81-111.

Kirschner, J. (2002): Juncaceae 3: Juncus subgen. Agathryon, Species Plantarum: Flora of the World 8. - Australian Biological Resources Study, Canberra. 192 pp.

Koopman, J. (2011): Carex Europaea: The genus Carex L. (Cyperaceae) in Europe, 1. Accepted names, hybrids, synonyms, distribution, chromosome numbers. - Margraf Publishers, Weikersheim, 726 pp.

Košanin, N. (1939): Über die Vegetation von Nordalbanien. - Srpska kraljevska akademija, Spomenik 89, Prvi razred 20: 73-107.

Kovács, F. (1915): Változások Óbecse flórájában. - Botanikai közlemények 14(1-2): 68-76.

Kranjčev, R., Šešok, D. (2016): A revision of the genus Fritillaria (Liliaceae) in Croatia. - Natura Croatica 25(2): 185-212.

Krasniqi, F. (1972): Šumska vegetacija brdskog regiona Kosova. Studije 27. Zajednica naučnih ustanova Kosova, Priština, 133 pp.

Kubát, K., Hrouda, L., Chrtek, J. jun., Kaplan, Z., Kirschner, J., Štěpánek, J. (eds.) (2002): Kličke květeně České republiky. - Academia, Praha. 928 pp.

Kupcsok, S. T. (1914): Adatok Bács-Bodrogmegye déli részének és Szerémmegyének flórájához/ Beiträge zur Kenntnis der Flora des südlichen Teiles des Komitats Bács-Bodrog und Syrmiens. - Magyar Botanikai Lapok 13(1-5): 81-96.

Laasimer, L., Kuusk, V., Tabaka, L., Lekavičius, A. (eds.) (1993): Flora of the Baltic Countries. Compendium of vascular plants 1. - Estonian Academy of Sciences, Latvian Academy of Sciences, Lithuanian Academy of Sciences, Tartu. 377 pp. 
Lakušić, D. (1999): Iris aphylla L. In: Stevanović, V. (ed.): Crvena knjiga flore Srbije 1. Iščezli i krajnje ugroženi taksoni: 73-74. - Ministarstvo za životnu sredinu Republike Srbije, Biološki fakultet Univerziteta u Beogradu, Zavod za zaštitu prirode Republike Srbije, Beograd.

Lampinen R. (2001): Universal Transverse Mercator (UTM) and Military Grid Reference System (MGRS). [http://www.luomus.fi/english/botany/ afe/map/ utm.htm]

Lányi, B. (1914): Csongrádmegye flórájának előmunkálatai/ Vorarbeiten zur Flora des Csongráder Comitates. - Magyar Botanikai Lapok 13(6-9): 232-274.

Lazarević, P., Stojanović, V., Jelić, I., Perić, R., Krsteski, B., Ajtić, R., Sekulić, N., Branković, S., Sekulić, G., Bjedov, V. (2012): Preliminarni spisak invazivnih vrsta u Republici Srbiji sa opštim merama kontrole i suzbijanja kao potpora budućim zakonskim aktima. - Zaštita prirode 62(1): 5-31.

Lubienski, M. (2011): Die Schachtelhalme (Equisetaceae, Pteridophyta) der Flora Deutschlands - ein aktualisierter Bestimmungsschlüssel. - Jahrbuch des Bochumer Botanischen Vereins 2: 68-86.

Lucchese, F. (2008): Equisetum x moorei Newman. In: Marchetti, D. (ed.): Notule pteridologiche italiche. VI (134-155): 215. - Annali del Museo Civico di Rovereto: Archeologia, Storia, Scienze Naturali 23: 205-226.

Liu, H-M., Russell, S. R., Vogel, J., Schneider, H. (2018): Inferring the potential of plastid DNA- based identification of derived ferns: a case study on the Asplenium trichomanes aggregate in Europe. - Plant Systematics and Evolution 304: 1009-1022.

Malo, S., Shuka, L. (2013): Distribution of Colchicum doerfleri Halácsy, Colchicum triphyllum Kunze and Colchicum bivonae Guss., in Albania. - International Journal of Ecosystems and Ecology Sciences 3(2): 273-278.

Markgraf, F. (1931): Pflanzen aus Albanien 1928. - Denkschriften der Kaiserlichen Akademie der Wissenschaften Klasse 102: 317-360.

Markgraf, F. (1932): Pflanzengeographie von Albanien. Ihre Bedeutung für Vegetation und Flora der Mittelmeerländer. - Bibliotheca Botanica 26: 6-132.

Marinescu, V. M., Alexiu, V. (2013): Iris aphylla L. ssp. hungarica critically endangered taxon in Europa. - Current Trends in Natural Sciences 2(3): 96-99.

Maslo, S., Šarić, Š. (2016): Fall panicgrass Panicum dichotomiflorum Michx. - A New Alien Species in the Flora of Bosnia and Herzegovina. - Herbologia 16(1): 15-22.

Mathew, B. (1984): Iris L. In: Davis, P. H. (ed.): Flora of Turkey and the East Aegean Islands 8: 382-410.

Mathew, B. (1996): A review of Allium Section Allium. - The International Board for Plant Genetic Resources, Kew.

Milović, M. (2017): Rod Colchicum L. (Colchicaceae) u flori Hrvatske. - Glasnik Hrvatskog botaničkog društva 5(1): 20-31.

Mossberg, B., Stenberg, L. (2003): Den nya nordiska Floran. - Wahlström \& Widstrand [Stockholm]. 975 pp.

Newman, E. (1854): New Irish Equisetum. - The Phytologist 5: 17-20. 
Niketić, M. (1986): Fitogeografske karakteristike Jelašničke klisure kod Niša. Unverzitet u Beogradu, Prirodno-matematički fakultet, Odsek za biološke nauke, Beograd. (graduate work, manuscr.) [in Serbian]

Niketić, M. (2000): Novi taksoni za floru cvetnica Srbije i susednih područja. - 6 . Simpozijum o flori jugoistočne Srbije i susednih područja, Zbornik rezimea, Soko Banja, 32-33.

Niketić, M. (2010): Novi taksoni za floru cvetnica Srbije i susednih područja 2. 10. Simpozijum o flori jugoistočne Srbije i susednih regiona, Apstrakti, Niš, 32-33.

Nikolić, V., Sigunov, A., Diklić, N. (1986): Dopuna Flori SR Srbije novim podacima o rasprostranjenju biljnih vrsta. In: Sarić, M., Diklić, N. (eds.): Flora SR Srbije 10: 259-351. - Srpska akademija nauka i umetnosti, Beograd.

Nobis, M., Nowak, A., Piwowarczyk, R., Ebel, A. L., Király, G., Kushunina, M., Sukhorukov, A. P., Chernova, O. D., Kipriyanova, L. M., Paszko, B., Seregin, A. P., Zalewska-Gałosz, J., Denysenko, M., Nejfeld, P., Stebel, A., Gudkova, P. D. (2016): Contribution to the Flora of Asian and European Countries: New National and Regional Vascular Plant Records, 5. - Botany Letters 163(2): 159-174.

Obradović, M. (1966): Biljnogeografska analiza flore Fruške gore. - Matica srpska, odeljenje za prirodne nauke, Novi Sad. 228 pp.

Obradović, M. (1986): Cenchrus incertus M. A. Curtis. In: Sarić, M., Diklić, N. (eds.): Flora SR Srbije 10: 242-242. - Srpska akademija nauka i umetnosti, Beograd.

Obradović, M., Boža, P., Panjković, V., Stanojev, R. (1984): Diferencijalne biljke subotičke peščare prema Deliblatskom pesku. - Univerzitet u Novom Sadu, zbornik radova Prirodno-matematičkog fakulteta, serija za biologiju 14: 69-79.

Obradović, M., Boža, P. (1985): Neke biljnogeografske odlike prolećne flore okoline Subotice. - Matica srpska, zbornik za prirodne nauke 68: 65-74.

Obradović, M., Boža, P. (1986): Prodromus flore papratnica i semenica Subotičke peščare i bliže okoline. - Univerzitet u Novom Sadu, zbornik radova Prirodnomatematičkog fakulteta, serija za biologiju 16: 121-142.

Obradović, M., Panjković, V. (1980): Prodromus flore papratnica i semenica Deliblatske peščare. - Zbornik radova PMF, serija za biologiju 10: 323-343.

Obradović, M., Panjković-Matanović, V. (1986): Adventivna flora Vojvodine. Matica srpska, zbornik za prirodne nauke 70: 99-114.

Obradović, M., Panjković-Matanović, V. (1988): Značaj nekih diferencijalnih biljaka Deliblatske peščare za floru Vojvodine. -Matica srpska, zbornik za prirodne nauke 75: 103-111.

Page, C. N. (1990): Hybrids in the genus Equisetum in Europe: an updated annotation. In: Rita, J. (ed.): Comunicaciones presentadas al Symposio "Taxonomía, Biogeografía y Conservación de Pteridófitos", Menorca, 27-30 de Octobre 1988, pp. 151-156. - Institut Menorquí d'Estudis, Societat d'història natural de les Balears, Palma de Mallorca. 
Pančić, J. (1856): Verzeichniss der in Serbien wildwachsenden Phanerogamen, nebst den Diagnosen eineger neuer Arten. - Verhandlungen der KaiserlichKöniglichen Zoologisch-Botanischen Gesellschaft in Wien 6: 475-598.

Pančić, J. (1863): Živi pesak u Srbiji i bilje što na njemu raste. - Glasnik Društva srpske slovesnosti 14(16): 199-233.

Pančić, J. (1865): Flora u okolini beogradskoj po analitičnom metodu: 295 pp. Kraljevsko-srpska državna štamparija, Beograd.

Pančić, J. (1867): Botanische Ergebnisse einer i. J. 1866 unternommenen Reise in Serbien. - Österreichische botanische Zeitschrift 17(6): 166-173, 201-209.

Pančić, J. (1874): Flora Kneževine Srbije: XXXIV + 802 pp. - Državna štamparija, Beograd.

Pančić, J. (1883): Građa za floru kneževine Bugarske. - Glasnik Srpskog učenog društva 53: 161-231.

Pančić, J. (1884): Dodatak flori kneževine Srbije: 253 pp. - Kralj.-srp. državna štamparija, Beograd.

Pančić, J. (1888 [1887]): Srpska kraljevska botanička bašta u Beogradu: 82 pp. Kralj.-srp. državna štamparija, Beograd.

Panjković-Matanović, V. (1989): Biljnogeografska analiza flore Vršačkih planina. - Matica srpska, odeljenje za prirodne nauke, Novi Sad. 140 pp.

Parabućski, S., Stojanović, S., Vučković, M. (1986): Zajednica Festucetum vaginatae danubiale Soó 29 na Subotičko-Horgoškoj peščari. - Matica srpska, zbornik za prirodne nauke 70: 129-134.

Perić, R., Stojšić, V., Panjković, B. (2009): Contribution to the flora of Serbia. $-5^{\text {th }}$ Balkan Botanical Congress. Book of Abstracts, Faculty of Biology, University of Belgrade, Serbian Academy of Sciences and Arts, Belgrade, 44.

Persson, K. (2007): Nomenclatural synopsis of the genus Colchicum (Colchicaceae), with some new species and combinations. - Botanische Jahrbücher fur Systematik, Pflanzengeschichte und Pflanzengeographie 127: 165-242.

Peruzzi, L., Francesca Caparelli, K., Bartolucci, F. (2009): Fritillaria messanensis subsp. neglecta (Parl.) Nyman, a fourth subspecies within Fritillaria messanensis Raf. (Liliaceae) from NW Balkans. - Candollea 64(2): 237-244.

Peruzzi, L., Innangi, M., Tatino, F., Santangelo, A. (2017): Fritillaria messanensis subsp. gracilis (Liliaceae), a new record for the Italian flora (S Italy). Phytotaxa 307(2): 167-170.

Petrova, A. S., Vladimirov, V. (2012): A contribution to the alien flora of Bulgaria. - Comptes rendus de l'Académie bulgare des Sciences 65(6): 771-778.

Petrova, A. S., Vladimirov, V., Georgiev, V. (2013): Invasive alien species of vascular plants in Bulgaria. - National Science Fund of the Ministry of Education, Youth and Science of the Republic of Bulgaria, Sofia.

Petrović, S. (1882): Flora okoline Niša. - Kraljevsko-srpska državna štamparija, Beograd, XXXII + 950 pp.

PPG I (2016): A community-derived classification for extant lycophytes and ferns. - Journal of Systematics and Evolution 54: 563-603. 
Prada, C. (1986): Equisetum L. In: Castroviejo, S., Laínz, M., López González, G., Montserrat, P., Muñoz Garmendia, F., Paiva, J., Villar, L. (eds.): Flora Iberica 1: 21-29. - Real Jardín Botánico, Madrid.

Prodán, Gy. (1910): Adatok Bács-Bodrogmegye és környékének florájához. Botanikai közlemények 9(3): 149-158.

Prodán, Gy. (1915): Bács-Bodrog vármegye flórája. - Magyar Botanikai Lapok 14(5-12): 120-269.

Prodán, J. (1935): Die Iris-arten Rumäniens. - Buletinul Grădinii Botanice şi al Muzeului Botanic dela Universitatea din Cluj 14(3-4): 105-198.

Rajevski, L. (1951): Novo nalazište Leontopodium alpinum Cass. u Srbiji. - Srpska akademija nauka, Zbornik radova 11, Institut za ekologiju i biogeografiju 2: 259-265.

Ranđelović, N. (1979): Brdske livade jugoistočne Srbije. In: Rauš, Đ. (ed.): Drugi kongres ekologa Jugoslavije, Zadar-Plitvice, 1-7.X.1979, pp. 939-955. -Savez društava ekologa Jugoslavije-Šumarski fakultet, Zagreb.

Ranđelović, N. (1979-1980): Šumska vegetacija planine Seličevice. - Univerzitet u Prištini, Prirodno-matematički fakultet, zbornik radova 6: 123-136.

Ranđelović, N. (1984): Rasprostranjenje biljnih vrsta u jugoistočnoj Srbiji (IV). Glasnik Prirodnjačkog muzeja u Beogradu, Serija B 39: 11-16.

Ranđelović, N., Hill, D. A., Stamenković, V. (1986): Colchicum hungaricum Janka. In: Sarić, M., Diklić, N. (eds.): Flora SR Srbije 10: 219-219. - Srpska akademija nauka i umetnosti, Beograd.

Ranđelović, N., Rexhepi, F., Jovanović, V. (1979): Biljne zajednice severoistočnog Kosova. In: Rauš, Đ. (ed.): Drugi kongres ekologa Jugoslavije, Zadar-Plitvice, 1-7.X.1979, pp. 957-995. - Savez društava ekologa Jugoslavije-Šumarski fakultet, Zagreb.

Randjelović, V., Zlatković, B. (1999): Ophrys mammosa Desf. In: Stevanović, V. (ed.): Crvena knjiga flore Srbije 1. Iščezli i krajnje ugroženi taksoni: 198-199, 462-463. - Ministarstvo za životnu sredinu Republike Srbije, Biološki fakultet Univerziteta u Beogradu, Zavod za zaštitu prirode Republike Srbije, Beograd.

Rechinger, K. H. (1935): Ergebnisse einer botanischen Reise in den Bertiscus (Nordalbanische Alpen). - Feddes Repertorium specierum novarum regni vegetabilis 38(13-25): 138-152; 319-389.

Rechinger, K. H., Randolph, L. F. (1954): Ergebnisse einer botanischen Reise in den Bertiscus (Nordalbanische Alpen). - Verhandlungen der ZoologischBotanischen Gesellschaft in Wien 94: 82-96.

Rexhepi, F. (1982): Fitocenoza Quercetum trojane dukagjini. - Zbornik radova PMF-a u Prištini 8: 221-233.

Richter, K. (1890): Plantae europeae. Enumeratio systematica et synonymica plantarum phanerogamicarum in Europa sponte crescentium vel mere inquilinarum 1. - Engelmann, Leipzig.

Rudsky, I. (1936): O vegetaciji planine Ošljaka. - Glasnik Hrvatskog Prirodoslovnog društva 41-48: 118-146. 
Rumy, K. (1846): Über das Klima Sirmiens. In: Zipser, C. A. (ed.): Die Versammlungen ungarischer Ärzte und Naturforscher: mit besonderer Beziehung auf die am 4. August $1842 \mathrm{zu}$ Neusohl abgehaltene dritte Versammlung: 48-55. - Neusohl [Banská Bystrica].

Ružić, M., Ranđelović, N. (1986): Vegetacija livada i pašnjaka Kosanice. In: Vučić, N. (ed.): Čovek i biljka, Zbornik radova sa naučnog skupa, 21-22. septembra 1983, pp. 455-467. - Matica srpska, Novi Sad.

Schlechter, R. (1918): Mitteilungen über einige europäische und mediterrane Orchideen I. - Repertorium specierum novarum regni vegetabilis 15(18-19): 273-302.

Scholz (2002): Panicum riparium H. SCHOLZ - eine neue indigene Art der Flora Mitteleuropas. - Feddes Repertorium 113(3-4): 273-280.

Schulzer, S., Kanitz, A., Knapp, J. (1866): Die bisher bekannten Pflanzen Slavoniens. - Verhandlungen der Kaiserlich-Königlichen Zoologisch-Botanischen Gesellschaft in Wien 16: 1-172.

Simon, T. (2000): A Magyarországi edényes Flóra határozója. Harvasztok virágos növények. - Nemzeti Tankönyvkiadó, Budapest. 846 pp.

Snogerup, S. (1980): Juncus L. In: Tutin, T. G., Heywood, V. H., Burges, N. A., Moore, D. M., Valentine, D. H., Walters, S. M., Webb, D. A. (eds.): Flora Europaea 5: 102-111. - Cambridge University Press, Cambridge.

Soó, R. (1927): Orchideae novae europeae et mediterraneae. Diagnoses, combinationes et nomina nova. - Repertorium specierum novarum regni vegetabilis 24 : $25-37$.

Soó, R. (1929): Revison der Orchideen Südosteuropas und Südwestasiens. Botanisches Archiv 23: 1-196.

Soó, R. (1959): Ophrys-Studien. - Acta Botanica Academiae Scientiarum Hungarica 5(1-2): 437-471.

Stace, C. (2010): New flora of the British Isles. - Cambridge University Press, Cambridge. 1248 pp.

Stanković, M. (2015): Florističke karakteristike staništa okoline Slavujevca (JI Srbija). Master rad. - Departman za biologiju i ekologiju, Prirodno-matematički fakultet Univerziteta u Nišu, Niš. (manuscr.).

Stevanović, J., Stavretović, N., Obratov-Petković, D., Mijović, A. (2009): I[n]vazivne biljne vrste na nekim sportsko-rekreativnim površinama Beograda. Acta Biologica Yugoslavica, serija G, Acta herbologica 18(2): 115-125.

Stjepanović-Veseličić, L. (1976): Iridaceae. In: Josifović, M. (ed.): Flora SR Srbije 8: 1-31. - Srpska akademija nauka i umetnosti, Beograd.

Tatić, B. (1975): Alliaceae. In: Josifović, M. (ed.): Flora SR Srbije 7: 568-592. Srpska akademija nauka i umetnosti, Beograd.

Tatić, B. (1976): Sesleria Scop. In: Josifović, M. (ed.): Flora SR Srbije 8: 325-330. - Srpska akademija nauka i umetnosti, Beograd.

Thiers, B. (2013): [continuously updated]. Index Herbariorum: A global directory of public herbaria and associated staff. New York Botanical Garden's Virtual Herbarium. http://sweetgum.nybg.org/ih 
Tison, J. M., Foucault, B. de (2014): Flora Gallica. Flore complete de la France. Société botanique de France, Biotope éditions, Mèze. 1196 pp.

Tomović, G., Vukojičić, S., Niketić, M., Zlatković, B., Stevanović, V. (2007): Fritillaria (Liliaceae) in Serbia: distribution, habitats and some taxonomic notes. - Phytologia Balcanica 13(3): 359-370.

Turland, N. J., Wiersema, J. H., Barrie, F. R., Greuter, W., Hawksworth, D. L., Herendeen, P. S., Knapp, S., Kusber, W-H., Li, D-Z., Marhold, K., May, T. W., McNeill, J., Monro, A. M., Prado, J., Price, M. J., Smith, G. F. (2018): International Code of Nomenclature for algae, fungi, and plants (Shenzhen Code) adopted by the Nineteenth International Botanical Congress Shenzhen, China, July 2017. - Regnum Vegetabile 159.

Vajgand, K. (1965): Prilog flori Bačke - osvrt na floru okoline Sombora. Diplomski rad. - Filozofski fakultet, Univerzitet u Novom Sadu(manuscr.).

Valdés, B., Scholz, H., Raab-Straube, E., Parolly, G. (2009): Poaceae (pro parte majore). In: Euro+Med Plantbase. [http://ww2.bgbm.org/EuroPlusMed/PTax onDetail.asp?NameCache $=$ Poaceae $\&$ PTRefFk $=7100000]\left(\right.$ retrieved October $6^{\text {th }}$ 2018).

Verloove, F., Sánchez Gullón, E. (2012): A taxonomic revision of non-native Cenchrus s.str. (Paniceae, Poaceae) in the Mediterranean area. - Willdenowia 42: $67-75$.

Vukićević, E. (1970): Pteridophyta. In: Josifović, M. (ed.): Flora SR Srbije 1: 59121. - Srpska akademija nauka i umetnosti, Beograd.

Vukićević, E. (1992): Pteridophyta. In: Sarić, M. (ed.): Flora Srbije 1: 71-160. Srpska akademija nauka i umetnosti, Beograd.

Vukićević, E., Diklić, N. (1975): Asparagaceae. In: Josifović, M. (ed.): Flora SR Srbije 7: 605-624. - Srpska akademija nauka i umetnosti, Beograd.

Vuksanović, S., Tomović, G., Niketić, M., Stevanović, V. (2016): Balkan endemic vascular plants in Montenegro - critical inventory, chorological and life forms analyses. - Willdenowia 46(3): 387-397.

Zlatković, B. (2011): Flora i fitogeografska pripadnost doline reke Pčinje u jugoistočnoj Srbiji. Doktorska disertacija. - Biološki fakultet, Univerzitet u Beogradu, Beograd, 380 pp. (manuscr.).

Wagner, W. H. J., Moran, R. C., Werth, C. R. (1993). Aspleniaceae. In: Flora of North America Editorial Committee (eds.): Flora of North America North of Mexico 2: Pteridophytes and Gymnosperms: 228-245. - Oxford University Press, New York, Oxford.

WCSP (World Check List of selected plant families) (2018): http://wcsp.science. kew.org.

Wilcox, M. (2010): A novel approach to the determination and identification of Juncus $\times$ diffusus Hoppe and $J$. $\times$ kern-reichgeltii Jansen \& Wacht. ex Reichg.

- Watsonia 28: 43-56.

Winter, W. de, Lubienski, M. (2012): Equisetum $\times$ ascendens Lubienski \& Bennert: de erste triploïde paardenstaartbastaard in Nederland.-Gorteria 36: 1-17.

Zorkóczy, L. (1896): Újvidék és környékének florája. - Popovits M. Testvérek Könyvnyomdája, Üjvidék [Novi Sad], 128 pp. 
180 Niketić, M. et al.: AnNOtated Checklist of Vascular Flora of SERbia I

МАТЕРИЈАЛ ЗА КРИТИЧКУ ЛИСТУ ВРСТА ВАСКУЛАРНЕ ФЛОРЕ

СРБИЈЕ. НОМЕНКЛАТУРНИ, ТАКСОНОМСКИ И ФЛОРИСТИЧКИ ПРИЛОЗИ I

МАРЈАН НИКЕТИЋ, ГОРДАНА ТОМОВИЋ, РАНКО ПЕРИЋ, БОЈАН ЗЛАТКОВИЋ, ГОРАН АНАЧКОВ, ВЛАДАН ЂОРЪЕВИЋ, НЕЈ ЈОГАН, БОРИС РАДАК, ШЕМИЈА ДУРАКИ, МИХАЈЛО СТАНКОВИЋ, НЕВЕНА КУЗМАНОВИЋ, ДМИТАР ЛАКУШИЋ, ВЛАДИМИР СТЕВАНОВИЋ

\section{Р Е 3 И М Е}

У раду су дате три нове номенклатурне комбинације везане за представнике породице орхидеја. Поред тога, приказано је 14 таксона (врста, подврста и хибрида) васкуларне флоре које су новорегистроване за Србију (од којих су 8 аутохтоних и 6 алохтоних биљака). Урађена је потврда старих или непоузданих литературних навода за четири аутохтона и један алохтон таксон у флори Србије. Четири биљна таксона представљају новину за ужу Србију, Војводину или Косово и Метохију, а за 7 биљака потврђено је присуство у појединим административним јединицама у Србији. У последњем делу рада, дат је приказ 9 оповргнутих таксона за нашу земљу. 